\title{
a new approach to the evaluation of peripheral vascular disease using the gamma camera
}

\author{
h. a.m. gerritsen
}

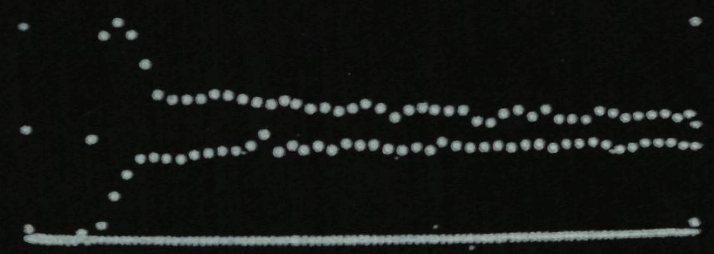




\section{A NEW APPROACH TO THE EVALUATION OF PERIPHERAL VASCULAR DISEASE USING THE GAMMA CAMERA}

H. A. M.GERRITSEN 
A NEW APPROACH TO THE EVALUATION OF PERIPHERAL VASCULAR DISEASE USING THE GAMMA CAMERA 
PROMOTORES:

PROF. DR. I. KAZEM

PROF. DR. P. J. F. M. KUIJPERS 


\title{
A NEW APPROACH TO THE EVALUATION OF PERIPHERAL VASCULAR DISEASE USING THE GAMMA CAMERA
}

\author{
PROEFSCHRIFT \\ TER VERKRIJGING VAN DE GRAAD VAN DOCTOR IN DE \\ GENEESKUNDE AAN DE KATHOLIEKE UNIVERSITEIT TE NIJMEGEN, \\ OP GEZAG VAN DE RE.CTOR MAGNIFICUS \\ PROF. DR. A. J. H. VENDRIK, \\ VOLGENS BESLUIT VAN HET COLLEGE VAN DECANEN \\ IN HET OPENBAAR TE VERDEDIGEN OP \\ VRIJDAG 11 JUNI 1976 DES NAMIDDAGS TE 4 UUR
}

DOOR

HENRICUS ALPHONSUS MARIA GERRITSEN

GEBOREN TE GOES 
This thesis is the outcome of work performed in the department of Radiotherapy and Nuclear Medicine (Chairman Prof. Dr. I. Kazem), and the department of Roentgendiagnosis (Chairman Prof. Dr. Wm. Penn). It would have been impossible without the facilities provided from the department of Cardiovascular Surgery (Chairman Prof. Dr. P. J. F. M. Kuijpers), referring the patients suffering from vascular disorders. 
To Carla,

Sya and Frank 


\section{ACKNOWLEDGEMENTS}

One of the pleasant features of writing a thesis is the opportunity it affords to the author to express his appreciations to those who have made the final result possible. In particular those, who have shown great patience with respect to unforeseen delays as well as changes in manuscript style and content, that were made in the interest of clarity and in an attempt to create an integrated text.

I acknowledge my debt to Drs. J. de Jong and Dr. Ir. A. Hasman (Physists of the department of Radıotherapy and Nuclear Medicıne) for their actual help and criticism. Furthermore thanks is recorded to Mr. R. T. Groothedde for his technical assistance.

It has been a pleasure to work with Mrs. Elly Verdık-Verbeeten and Mrs Marıa Janssen-Derks, who have given indispensable help durıng patients examınations. Thanks must be recorded here to all technıcians, who without mentionıng their names have contributed to thıs work.

I gratefully acknowledge my indebtedness to Drs. J. A. M van Druten (Mathematısch-Statistısche Adviesafdelıng, Chairman Drs. P. van Elteren), whose statistical analysis of the obtained results gave this work more significance.

J am indebted to Mr. W Witte, photographer of the department of Roentgendiagnosis, who has logetronically photographed the pictures of the arteriograms included in this thesis.

Thanks is also extended to the department of Medical Illustration, (Head Mr. J. J. M. de Bekker), for the diagrammatıc ıllustratıons. Also st was a pleasure to work with Mr. A. T. A Reynen (Head of the department of Medical Photography), who offered excellent service in respect to all the additional reproductions of the illustrations

Without a library an author would be helpless. In this respect I am deeply indebted to Mr. E. de Graaff (Head of the Medical Library).

It has been very pleasant to receive the fullest co-operation from the publisher Mr. Th. Busser (Drukkerıj Brakkensteın), smoothıng out the diffıcultıes inherent in publishing a thesis.

Finally it is difficult to sufficiently thank Miss Thera Reitsma and Mrs. Annemie Husbers-Dorssers, who have typed and retyped the manuscript with enthusiasm, patience and accuracy. 
CHAPTER I. INTRODUCTION

1.1. Historical note

1.2. Review of tracer techniques for the evaluation of peripheral circulation . . . . . . . . . . . . . 14

1.2.1. Local clearance techniques . . 14

1.2.2. Non-diffusible isotope techniques $\quad 15$

$\begin{array}{ll}\text { 1.2.3. Labeled-particles techniques } & 16\end{array}$

1.2.4. Radionuclide angiography . . . . . . 17

1.3. Review of techniques other than tracer studies for evaluation of peripheral circulation . . . . . . . . . . . . . 17

1.3.1. Venous occlusion plethysmography . 17

$\begin{array}{ll}\text { 1.3.2. Distal blood pressure measurements . } & 18\end{array}$

1.3.3. Ultrasonic techniques . . . . 19

1.3.4. Treadmill . . . . . 19

1.3.5. Thermography . . 20

$\begin{array}{ll}\text { 1.4. Purpose of present investigation } & 20\end{array}$

CHAPTER II. TECHNIQUE 21

2.1. Introduction. . . . . . . 21

2.2. Description of a new tracer technique . 21

2.3. Radionuclide . . 22

2.4. Radiation dose $\quad 22$

2.5. Bolus injection. 23

2.6. Reactive hyperemia . 24

2.7. Gamma camera system 25

2.8. Processing and display 26

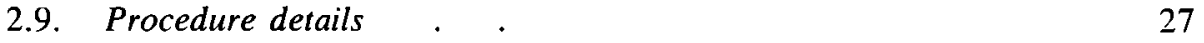

2.10. Arteriographic technique . 28 
3.1. Main groups. . . . 30

3.2. Arteriographic interpretation . 30

3.3. Arteriographic classification . . . . . 31

3.4. Relation of the subgroups to patient group . 32

3.5. Incidence of anatomic localizations $\quad 32$

3.6. Follow-up control 33

CHAPTER IV. PATTERN ANALYSIS AND CLINICAL INTERPRETATION OF THE TRACER TEST . . . . . . . 34

4.1. Introduction. 34

4.2.1. Normal pattern . . $\quad 34$

4.2.2. Physiologic interpretation . 36

4.3.1. Early pathologic changes . 36

4.3.2. Clinical interpretation . . $\quad 38$

4.4.1. Pattern in obstructive disease . . . . . $\quad 38$

4.4.2. Localization interpretation of involved segment . 44

4.4.3. Indications of pathologic run-off . . 44

4.4.4. Discussion and theoretical considerations 50

4.5.1. Pattern after vascular reconstruction 50

4.5.2. Discussion . . . . . . . . . . . 58

4.6.0. Pattern anomalies due to factors other than arteriosclerosis obliterans . . . . . . . . . . . . 58

4.6.1. Injection in cephalic vein . 58

4.6.2. Discussion . . . . . . . . . . . 59

4.6.3. Pseudo-pathologic curve pattern due to cuff resistance 60

4.6.4. Discussion . . 61

CHAPTER V. STATISTICAL ANALYSIS OF THE RESULTS . 62

5.1. Introduction. . . $\quad 62$

Group A: normal subjects $\quad$. $\quad$. 62

5.2. Differences in parameter values in right and left leg of the same subject . . . . . . . . . . . . . . . 62

5.3. Differences in parameter values obtained in men and women . . $\quad 63$

5.4. Correlations of the measured parameters with the age of man and women separately . . . . . . . . . . . 64

$\begin{array}{lllll}\text { 5.5. Discussion . . . . . . . . . . } & 64\end{array}$ 
Group B: patients $\quad$. $\quad$. $\quad 65$

5.6. Clinical classification correlated to angiographic diagnosis . $\quad$. 65

5.7. Comparison of angiographic diagnosis in the same patients related to the tracer parameters . . . . . . . . . . . 66

5.8. Relationship between tracer parameters and arteriographic diagnosis in legs. . . . . . . . . . . . . . . . . 72

$\begin{array}{ll}\text { 5.9. Illustrative case reports . . . } & 77\end{array}$

5.9.1. Case report (K.v.W.) 77

$\begin{array}{lll}\text { 5.9.2. Case report (A.v.d.K.) } & 78\end{array}$

$\begin{array}{lll}\text { 5.9.3. Case report (J.S.) - } & 78\end{array}$

5.10. Discussion . . . . . . . . $\quad 83$

5.11. Treatment possibilities in the patients studied. 84

5.12. Changes in P.I. after management . . . . . . . . . . $\quad$. 85

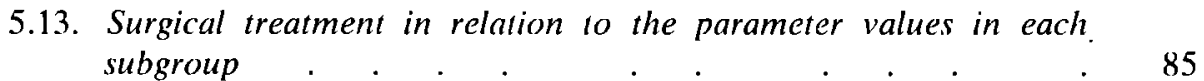

5.14. Illustrative case report . 93

5.14.1. Case report (V.A.) 93

5.14.2. Case report (P.R.) 93

5.14.3. Case report (O.-C.) . 97

5.14.4. Case report (B.-L.) . 100

$\begin{array}{ll}\text { 5.15. Discussion } & 100\end{array}$

$\begin{array}{ll}\text { SUMMARY } & 107\end{array}$

$\begin{array}{ll}\text { REFERENCES } & 110\end{array}$

$\begin{array}{ll}\text { CURRICULUM VITAE } & 120\end{array}$ 


\section{PREFACE}

Arteriosclerosis obliterans is primarily a disease of elderly men Females constitute only about $15 \%$ of the patients Lately there has been a tendency of increasing incidence among the 30-50-year-age group The exact cause of the disease is unknown Several diseases are predisposing factors such as diabetes mellıtus, hyperlipemic states, certain blood dyscrasıas etc Other well known factors playing an important role as well are hypertension, smoking habits, obesity, stress conditions etc $W_{1}$ th increasing age, atherosclerotic plaques in the vessel wall are formed followed by a thrombotic process causing narrowing and finally occlusion of the vessels

As a result impaired blood supply in the limb occurs with a decrease in the oxvgenation of the skeletal muscles The muscle cells adapt their metabolic activity to the hypoxic condition resulting in the release of metabolic products such as lactic acid causing the claudication pain

In the last decades great progress has been achieved in the field of vascular surgery Thanks to improved technıques and advances in anesthesıa, successful vascular surgery is now possible for the corrections of vascular impairment to limbs and other organs The selection of patıents with peripheral vascular disease for corrective surgery requires adequate assessment of the vascular function It is therefore necessary to devise a test, which would provide accurate estimation of the degree of impaired perfusion and of the extent of the improvement after treatment Such a test must be also useful in detecting perfusion insufficiency even in the absence of a satısfactory history of intermittent claudication It should also enable the clinician to differentiate between intermittent claudication, and disorders of an orthopedic, neurologic and psychosomatic nature

Arteriographic examindtions provide invaluable anatomic information of the site and extent of an arterial lesion However the obtained images lack the functional aspect of muscle perfusion Also arterıography has a certan risk due to complications, necessitating hospitalization, which renders the technique unsuitable as a screening test

We are aware of the many tests of peripheral arterial insufficiency, which crowd the literature Most of these tests are only useful as a research tool Very few are applicable to clinical practice The introduction of the gamma camera made it possible to monitor the distribution of suitable radionuclides in body organs Contınuous monitoring enables the investigator to obtain pictures in rapid sequences to visualize the movement of the radionuclide through organs The detected data can be recorded or processed by a computer or another suitable 
data analyzer. In such a way it is possible to obtain curves of count rate versus time of any selected region. The obtained information in curves and pictures depicts the distribution of the radionuclide in the organs as well as any subsequent changes characterizing (patho)physiologic events. Applying the radionuclide tracer technique and the gamma camera provides a new non-invasive approach to the dynamic evaluation of the arterial perfusion in the leg. 


\section{CHAPTER I}

\section{INTRODUCTION}

\section{Historical note}

The earliest classical method for investıgatıng blood flow was based on recording volume changes of the extremity, and was called venous occlusion plethysmography It was introduced by Hewlett and van Zwaluwenburg (1909) As the application of the method is time-consuming and often difficult, plethysmography was mainly used for labordtory work in experımental physiology (Lewis and Grant, 1925) The lack of large-scale clinical experience with venous occlusion plethysmography might explain the fact that since the dawn of radioactıvity so many investigators have been interested in the measurement of blood flow using radioisotopes

As early as 1927 Blumgart et al utılized radioactive substances in the study of blood velocity Their method consisted of injectıng a radioactive deposit into the antecubital vein of one arm, detecting the arrival in the opposite arm with a shielded Wilson cloud chamber They reported that arm-to-arm circulation time was 28 seconds Later they used an ionization chamber of the type designed by Geiger for the detection of radioactivity The radioactive substance used was radium-B $\left({ }^{214} \mathrm{~Pb}\right)$ in equilibrium with its decay products $\mathrm{Ra}-\mathrm{C}$ and $\mathrm{Ra}-\mathrm{C}^{\prime}$ Although Ra-B rapidly decays with a half life of 268 minutes, the disintegration product radium-D, which is also a radioactive isotope of lead (210 Pb), remains with a half life of 194 years The latter isotope accumulates in bone and produces prolonged radiation burden

The development of more suitable radioactive isotopes stimulated Hubbard (1942) and later Smith and Quimby (1945) to employ radioactive sodium for tracer experıments A few cubic centımeters of ${ }^{24} \mathrm{Na}$-contaınıng salıne were rapidly injected into an arm vein, and the arm-to-foot circulation time was determined The variations in the obtained circulation time values found in normal subjects under restıng conditions were so wide as to render these results valueless in clinical diagnosis of circulatory disorders

Elkın et al (1948) employed a sımılar technique to derıve a "Circulatory Index" calculated from the equilibrium curve of $32 \mathrm{P}$ in tissues after intravenous injection The results obtained with ${ }^{32} \mathrm{P}$ were similar to those obtained with ${ }^{24} \mathrm{Na}$ 


\subsubsection{Local clearance techniques}

An indirect way of measuring blood flow to a region of the body is to inject a radioactive isotope into this region and to measure the rate of removal of the activity from the site of injection. Such a technique is called a clearance technique. Kety (1949) proposed a mathematical analysis of the clearance of a bolus of ${ }^{24} \mathrm{Na}$ injected into the calf muscle. He assumed that the tissues were homogeneous, that is to say, they had no concentration gradients to the tracer, that the equilibrium between blood and tissue was immediate, and that the isotope was removed only by blood flow from the site sensed by the external detector of radioactivity. The results were expressed as flow per unit volume or per unit mass of tissue after appropriate corrections.

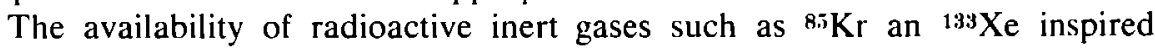
Lassen (1964) to apply them to the clearance technique. ${ }^{85} \mathrm{Kr}$ and ${ }^{133} \mathrm{Xe}$ are lipid-soluble gases that readily cross the cellular membrane of capillary endothelium and diffuse into tissues without being metabolized. Significant recirculation is not possible, because with each passage through the lungs 95 per cent of the gas diffuses into the alveoli. The technique introduced by Lassen (1964) was widely used (Bell et al., 1968; Hoffmann, 1968; Puel et al., 1968; Larsen, 1972), although it is open to several criticisms.

For external monitoring the physical characteristics of ${ }^{133}$ Xenon are important. ${ }^{133} \mathrm{Xe}$ is a gamma emitter with a photon energy of $81 \mathrm{KeV}$. Because the energy is low, scattered radiation cannot be eliminated easily from the photopeak by pulse-height analysis. This reduces the spatial resolution of the measured data (Holman et al., 1974). Furthermore the mass attenuation coefficient for $81 \mathrm{KeV}$ photons is high; as a result, blood flow measurements are weighted more heavily toward superficial tissue lying closer to the external detector than from deep structures (Holman et al., 1972; Zimmerman et al., 1972). Both compartmental and stochastic analyses result in a specific flow in $\mathrm{ml} / \mathrm{min} / 100 \mathrm{~g}$ of tissue throughout which the tracer has been distributed (Ziegler, 1965). Absolute flow in $\mathrm{ml} / \mathrm{min}$ cannot be measured without knowing the weight of the organ or region which is monitored. Furthermore, for most normal tissues specific flow measurment is not diffusion-limited. However, when poorly perfused structures are studied, this constraint may not be met. The limited diffusion of poorly perfused tissue results in a situation where the washout of tracer is not only proportional to flow but also to the time for the tracer to diffuse to the capillary tissue interface, resulting in lower flow values (Clausen et al., 1971; Grimby et al., 1967).

Other inherent limitations include: the possible introduction of geometric errors (Alpert et al., 1966), the difficulty to determine the tissue partition coefficient (i) (Conn, 1961; Andersen et al., 1967; Kjellmer et al., 1967), and the difference of the partition coefficient of Xenon for muscle and that for 
fatty tissues by a factor of ten (Lindbjerg et al, 1966) There are differences in values derived from normal tıssues and from diseased tissues Undoubtedly there are differences among normal values as well (Lindbjerg et al, 1965) resultıng in normal values overlapping with the range of pathologic values (Bell et al , 1968, Lindbjerg et al , 1966a, Larsen, 1972) More significant is the report of Hebestreit et al (1972), who found difficulty in obtaining relıable blood flow values after reconstructıve surgery Furthermore the technique is rather time-consuming (Alpert et al, 1966)

In spite of all the shortcomings the application of local 133Xenon clearance technıque greatly expanded the pathophysiologic knowledge of peripheral circulation in arteriosclerosis obliterans The inherent limitations, however restricted the technıque in routıne clınıcal use

\section{Non-diffusible ssotope technıques}

The method introduced by Smith and Quimby (1945) was later modified by Krieger et al (1952) and MacIntyre et al (1952) employıng a non-diffusible radiopharmaceutical, 1 e 111 -labeled human serum albumin Following the intravenous injection of the tracer, an activity-tıme curve measured over an extremity was obtained They interpreted the risıng part of the activity curve as expressing the mixing of radioactivity in plasma, which is very closely related to flow, and suggested that the final height of the plateau is indicative of the volume of the vascular bed The use of a non-diffusible tracer only assesses intravascular blood flow because there is no diffusion to extracellular space and tissues

Cuypers et al. (1962 and 1964) employed a technıque simılar to that of Mac Intyre and reported that they could not differentiate between normal subjects and patients with occlusive disease under resting conditions The flow values obtained at rest were sometimes even higher in patıents with obliterative disease than in normal subjects This is in agreement with a report published by Hess (1956), who obtaıned sımılar results usıng d plethysmographic technıque When Cuypers et al repeated the test durıng hvperemic reaction following a period of ischemia, they were able to define a tıme parameter which was used in differentiatıng between normal and pathologic values They did not succeed, however, in establıshıng a precise mathematical analysis of blood flow nor did they obtain a consistent correlation between the obtained data and the clinical status.

A major difficulty, makıng an absolute measurement of flow in $\mathrm{ml} / \mathrm{min}$ impossible, is the fact, that there is no way of estımatıng the degree of increased plasma volume during hyperemic reaction Besides it is difficult to measure the variability of the tracer concentration in the blood plasma

The measurement of flow using a non-diffusible indicator is based on determinıng the transit tıme This is the tıme required to traverse the system from entrance to exit In vascular systems the situation is rather complex due to the 
presence of several and different pathways through the conduit. Those tracer molecules appearing at an earlier time could have traversed a shorter total path length than those appearing at a later time. In such cases a distribution of transit time values is obtained requiring the introduction of a mean transit time. This mean transit time is related to both flow and volume of distribution. The blood volume in the organ of interest during reactive hyperemia is variable and cannot be measured non-invasively. Transit time measurement alone therefore does not provide a quantitative measure of blood flow (Cuypers, 1967; Zierler, 1965).

Interpretation of time-activity curves is empirical since the resultant curve is a composite of flow and volume. The registration of markedly increased vascular volume during reactive hyperemia was reported by Lambert et al. $(1950,1951)$. In dog experiments they obtained higher venous blood flow after a period of ischemia of a muscle group perfused directly, than from a muscle group perfused by collaterals. Normally during reactive hyperemia there is a temporary increase in vascular volume, whereas this is less important in patients with occlusive vascular disease. There is also a direct relation between the duration of reactive hyperemia and the preceding ischemic period. During reactive hyperemia the blood flow through the collateral circulation is decreased compared to direct perfusion. Shepherd (1950) also reported that after muscular exercise the directly measured blood flow values in peripheral occlusive disease never reached the blood flow values obtained in normal subjects.

\subsubsection{Labeled-particles techniques}

Another approach to assess local perfusion is the use of labeled microspheres as reported by Wagner et al. (1965) and Flores Izquierdo et al. (1968). The principle behind the use of microspheres is based on the premise that its regional uptake is proportional to blood flow. Particles of a size greater than capillary dimensions are trapped by arteriolar and capillary blockade in the first vascular bed downstream from the injection site, unless they escape through arteriovenous anastomoses greater in size than the particles. The distribution of the cardiac output of such particles, when well-mixed in the left atrium, is proportional to the arterial blood flow to an organ. This means that it is proportional to the microcirculatory flow but does not include shunted flow through vessels greater in diameter than the particles. The microsphere technique therefore can only be used to determine relative peripheral blood flow. Because left atrial injection is not feasible, microspheres are injected directly into the organ-supplying artery, and scans of the organ are performed.

Giargiana et al. (1973) demonstrated that in patients with peripheral vascular disease perfusion scans obtained under resting conditions did not always provide an accurate evaluation of the pathophysiologic changes as present in chronic occlusion. The lack of correlation to angiograms in about 50 per cent of the 
cases might be due to inadequate mixing of the microspheres at the time of injection into the aorta.

Recently Siegel et al. (1973) introduced intra-arterial injections of $99 \mathrm{~m} \mathrm{Tc}$ and 113 'In-labeled albumin microspheres during reactive hyperemia. Under maximal dilatation of the vascular bed an essentially different perfusion was present. When the vasculature was stressed they were able to demonstrate a good correlation between the subjective findings of claudication and the peripheral perfusion changes as visualized on the scan. Although this procedure has significantly improved the results, it is a rather sophisticated technique enjoying less clinical popularity due to the necessity for intra-arterial injection tempered with a natural caution against producing capillary blockade in vital organs (Holman et al., 1974). Also the technique is qualitative and not quantitative.

\subsubsection{Radionuclide Angiography}

An approach to visualize greater arterial vessels is referred to as radionuclide angiography. This procedure is mainly useful for investigating the heart and major cerebral arteries (Powell et al., 1966; Kriss et al., 1971; Ischii et al., 1971). Radionuclide angiography as a test to demonstrate obliterative arterial disease beyond the abdominal aorta was reported for the first time by Rosenthall (1966), and later by Dibos et al. (1972), Kappert et al. (1972), and Heidenreich et al. (1973). The technique, however, lacks the resolution necessary to provide anatomical details as seen with conventional arteriography and essential if vascular surgery is contemplated. Small arteries are not resolved, and no information is obtained about run-off vessels.

\subsection{Review of techniques other than tracer studies for evaluation of peripheral circulation}

An exhaustive review of all available methods assessing physiologic changes in peripheral circulation is beyond the scope of this thesis. Perhaps the most accurate, though impractical, method is the direct intra-arterial measurement of flow and pressure at several segments of the limb. The most commonly utilized methods for peripheral blood flow measurements are reviewed below.

\subsubsection{Venous occlusion plethysmography}

The technique was introduced by Hewlett and van Zwaluwenburg (1909) as mentioned before. Later numerous investigators modified the technique. Grill (1933) replaced the rigid cuffs of glass or metal utilizing thin rubber membrane cuffs. Shepherd (1950) as well as Dohn et al. (1952) worked out this principle 
and recorded volume changes of the extremity as pressure changes in the cuff, i.e. volume plethysmography.

Whitney (1949) adopted an entirely different principle measuring the change in circumference of the extremity by recording the electric conductivity of a mercury-in-rubber resistance strain gauge.

Several studies were reported subsequently where both plethysmography and ${ }^{133} \mathrm{Xe}$ muscle clearance were simultaneously used for evaluation of the blood flow in skin and muscle in normal subjects and in patients with arterial obliterative disease (Lassen et al., 1965; Barcroft et al., 1967; Bonde Petersen et al., 1967; Siggaard-Andersen et al., 1967). There was good agreement between the obtained results during high flow-volume, i.c. when a maximal vasodilatation was elicited. In clinical routine the ${ }^{133} \mathrm{Xe}$ clearance provides neither more nor better information than venous occlusion plethysmography (Siggaard-Andersen et al., 1967). Also venous occlusion plethysmography gives no information about the condition of the arteries in the lower leg.

\subsubsection{Distal blood pressure measurements}

Extensive work on measuring the distal blood pressure was reported by Strandness et al. (1969). Originally mercury strain gauge was utilized. Later distal blood pressure was measured with several techniques utilizing digital pulse plethysmography (Fagrell, 1973), or by measuring systolic ankle pressure with Doppler ultrasound, where the transducer of the ultrasound is used as a stethoscope over the pedal arteries (Bollinger, 1973).

Recently Nielsen et al. (1973 b) utilized a photoelectric probe and external counter-pressure. The use of blood pressure gradients has improved the localization of occlusion. Also utilizing the difference in the systolic pressure between arm and ankle as a systolic pressure index has proved to be a useful parameter in assessing the severity of ischemic disease in clinical practice, especially when the measurements are performed after exercise or after circulatory arrest. However in measurement of the distal blood pressure there is a considerable dayto-day variation, similar to what is found in measurements of blood flow utilizing venous occlusion plethysmography (Nielsen et al., 1973 a).

Furthermore the technique has the following limitations:

1. It measures the systolic pressure only.

2. The values are often exaggerated, particularly at the upper thigh level.

3. It is difficult to perform in patients with large limbs and impossible in those with medial calcification of the arteries (Strandness, 1969).

Holstein et al. (1973) and Lassen (1974) combined the measurement of distal blood pressure in skin and muscles with radioisotope clearance technique. After intradermal injection of ${ }^{133} \mathrm{Xenon}$ or alternatively 4 -Iodo-antipyrine tagged with 
${ }^{131}$ I or ${ }^{125}$ I the clearance was measured utilizing a counter-pressure by means of a PVC plastic bag filled with air to form a pillow interposed between the skin depot and the cuff. When the clearance stops, the local skin perfusion pressure is determined. However, this technique is rather time-consuming and skin edema presents special problems in performing the procedure. Its major applicability is in patients with legs presenting a serious degree of obliterative disease where it offers an objective method of assessing the level of amputation.

\subsubsection{Ultrasonic techniques}

Recently a non-invasive method for the measurement of peripheral arterial blood flow was introduced based on the Doppler effect and echography. In this application of Doppler techniques, a narrow ultrasonic beam is directed to traverse a blood vessel. Because erythrocytes are much smaller than the wavelength of sound used, they behave as point scatterers, mostly directed back toward the transducer. The frequency of the back-scattered sound is dependent on the velocity of the erythrocyles according to the Doppler principle. Doppler instruments, however, measure blood velocity and not blood flow.

For the calculation of blood flow from the measured velocity the following equation is used:

$$
\mathrm{F}=\mathrm{A} \cdot \mathrm{V}_{\mathrm{I}}
$$

where $\mathrm{F}$ is the blood flow, $\mathrm{A}$ is the cross-sectional area of the artery, and $\mathrm{V}_{\mathrm{a}}$ is the average velocity. Echographic techniques are commonly combined with Doppler techniques for the determination of the arterial cross-sectional area.

Although these techniques are still in the developmental phase, there are current limitations:

1. Few arteries are accessible to ultrasonic detection.

2. Tortuosity of bifurcated arteries makes interpretation difficult.

3. When the distance between the vessels and the skin is more than $9 \mathrm{~cm}$, meaningful results are difficult to obtain, especially when the flow rate is low.

It is hoped that in the future the above problems will partly be solved, making the technique easier to apply. In spite of these limitations ultrasonic detections are useful in measuring distal blood pressure (1.3.2.) (Bolinger, 1970; Myhre, 1973).

\subsubsection{Treadmill}

A clinically useful test objectively estimating the arterial function in arteriosclerosis obliterans is the walking distance. However, there are many variables, 
such as body weight, threshold of pain, and how the patient walks (Strandness, 1969), making the end-point unreliable. Even on the treadmill, where the patient is forced to walk at a fixed rate, patients frequently overexert themselves to impress the physician with the amount of improvement they can demonstrate.

\subsubsection{Thermography}

Among the wide spectrum of available techniques for evaluating peripheral vascular disease, thermography is the least successful. More recent reports consider the technique of thermography as unsuitable for the diagnosis of peripheral arterial disease (Sörensen et al., 1973; Scherster et al., 1973; Buchwald et al., 1973).

\subsection{Purpose of present investigation}

The angiogram provides essential clinical information of the peripheral circulation which is readily available to the surgeon and applicable to the patient. Angiographic techniques permit an accurate, detailed visualization not only of the normal anatomy, but also the location of vascular disease and collateral pathways.

However it does not provide an accurate indication of the extent of the functional impairment. Furthermore, in chronic occlusive disease of the lower leg the tibial arterial system is frequently poorly outlined or even fails to be visualized. Such information is of great importance because if there is occlusive disease in the distal arteries compromizing the distal run-off, vascular surgery on large vessels may be of limited or no value.

An accurate screening technique for the evaluation of patients with mild complaints such as muscular weakness or pain during walking is desperately needed. Clinical assessement of the arterial pulses can be very misleading. On the other hand an angiographic investigation is a traumatic procedure, which requires hospitalization in view of possible serious complications (Scherer, 1972; Suy et al., 1973) including bleeding and allergic reactions to iodine-containing contrast agents (Pendergrass et al., 1960; Witten et al., 1973; Wilder et al., 1960).

From the above review it is clear that none of the many available methods evaluating peripheral circulation is clinically satisfactory. There is still a need for an objective test which could serve as a reliable index of the degree of arterial dysfunction, as a useful screening test prior to arteriography, and as a functional assessment of vascular reconstruction.

In this thesis a new approach is presented for the evaluation of peripheral circulation employing what is thought to be an atraumatic, reproducible and diagnostically decisive technique. 


\section{TECHNIQUE}

\subsection{Introduction}

In ischemic disease of the extremities the history and physical examination of the patient provide valuable clues to the location and extent of intravascular pathology. Angiography is required for detailed anatomical information of the larger vessels when reconstructive surgery is anticipated. As mentioned before, the dynamic aspects of peripheral perfusion are largely missing in a static study like angiography. The claudication status, expressing ischemia in the limb, most frequently occurs when the circulation is stressed by exercising muscles.

Hishida (1963) suggested that the function of the vascular system during maximal dilatation of the vessels is indicative of the reaction of the extremities to exercise. Evaluation of peripheral perfusion during maximal vasodilatation therefore provides clinically useful information otherwise not obtained from angiographic studies.

Previous techniques assessing obliterative disease in the leg have been reviewed in chapter I. As mentioned before many of these techniques have greatly enhanced our knowledge of the pathophysiology of the circulation in the extremities. Clearance techniques as described by Lassen (1964) as well as labeled-particles techniques as suggested by Wagner et al. (1965), have their limitations in clinical use. Kety (1949) stated that the effectiveness of the circulation is best measured in terms of its total ability to supply freely diffusible substances.

\subsection{Description of a new Tracer Technique}

In this thesis a new approach to the functional assessment of occlusive vascular disease is introduced, based on the use of a diffusible tracer and the gamma camera system. Under conditions of maximum reactive hyperemia in a limb the appearance and distribution of an intravenously injected bolus of 99"'Tc-pertechnetate is monitored for a few minutes.

Activity-time curves as well as serial scintiphotos of the activity distribution in the part of the limb under study are obtained. The activity distribution as 
visualized and measured at any chosen time during the study reflects the state of local perfusion at that time. Comparison of the degree of perfus'on can then be made between different areas of the same limb as well as to the other limb by utılizıng the data processing system of the gamma camera.

\subsection{Radionuclide}

Harper (1962) introduced 9911 Tc-pertechnetate as a freely diffusıble tracer with a half life of six hours. Using a radionuclide generator, it is possible to obtain daugther radioactive isotopes with a short half life from a radioactive mother element with a prolonged decay. The ${ }^{99 m}$ Tc generator is a glass cylinder shielded by lead, containing the sterile mother element ${ }^{99}$ Molybdenum with a half life of 67 hours. Elution of the generator with sterile physiologic saline yields ${ }^{99}$ Technetıum as a salt solution $\mathrm{Tc}_{4}^{-}$(Technetıum-pertechnetate) ${ }^{99}$ "1 Tc is a metastable phase in the decay of "Molybdenum, which through the emission of gamma rays with an energy of $140 \mathrm{KeV}(98.6 \%)$ and $142 \mathrm{KeV}$

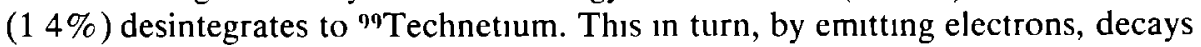
to stable ${ }^{94}$ Ruthenıum with a half life of $2.1 \times 10^{5}$ years. ${ }^{99 m}$ Tc-pertechnetate has a very useful energy for detection by gamma cameras.

\subsection{Radiatıon Dose}

991'Technetıum-pertechnetate has a very short physical as well as biological half life, permitting parenteral injection of a diagnostically sufficient amount of millicurie activity with a tolerable radiation dose delivered to the patient. The radiation dose delivered to the whole body following the administration of $8 \mathrm{mCi}$ of ${ }^{99}$ inc-pertechnetate is less than 100 mrads (ICRP Publication 17 Protection of the Patient in Radionuclide Investigations).

The radiation dose to the investigator's hands and fingers is about 25 mrads assuming 10 seconds of handling. The dose to parts of the body within a distance of $10 \mathrm{~cm}$ from the nuclide-containing syringe is less than $1 \mathrm{mrad}$. McEwan (1969) estımated the mean tıme for normal routıne intravenous injections as $40-50$ seconds.

When measuring with finger dosimeters the skin dose to the hand was calculated as 120 mrads per minute per $10 \mathrm{mCi}$ of 99 m. Tc. Nell (1969), using the same technique, reported a radiation dose to the hand of $10 \mathrm{mrad}$ per mCi per minute. The International Commission on Radiological Protection has set the maxımum permissible radiation dose delivered to the hands at 75 rad per year or 1500 mrad per week. In the Netherlands the maxımal dose to hands as defined in the "VBIS" (Velligheidsbesluit 1oniserende stralen) is $60 \mathrm{rad}$ per year.

Following intravenous injection of the $99 \mathrm{~m}$ Tc-pertechnetate the plasma concentration falls to 50 per cent within two hours (Westerman, 1968). There is, 
rapid excretion during the first 24 hours after injection initially via the kidney, and mainly by the GI-tract thereafter.

\subsection{Bolus Injection}

In dynamic tracer studies, in which the rapid process of arrival and distribution of the activity is closely related to blood flow, a simple and standardized bolus injection technique is required.

Oldendorff (1965) suggested a cuff release technique using a "Velcro" cuff, permitting abrupt decompression. The rapid transport of the intravenously injected activity is based on the rise of the venous blood pressure of the blood pool in the distal arm due to a cuff pressure of $100 \mathrm{mmHg}$, provided this pressure is below the systolic pressure. After swelling of the venous vessels the cuff pressure is increased above the systolic pressure to cut off the arterial circulation as well. A deposit of radioactivity is injected in an antecubital vein and, after withdrawal of the needle, the cuff is removed abruptly.

Another procedure is the technique described by Lane et al. (1972). This method is based on using a saline flush to aid the central passage of the bolus. Watson et al. (1973) reported that Oldendorff's technique results in the delivery of the nuclide in the more laterally located cephalic vein group and in a spreading of the bolus in time, and frequently to actual division of the bolus in two discernible components. The cause of this phenomenon is the delay in passage of the radioactive bolus encountered at the junction of the cephalic and axillary veins. No such delay was observed when the nuclide was injected into the basilic vein group; this vein, however, is not always accessible.

In our studies we adopted the saline flush technique for bolus injection. We used a $1.2 \mathrm{~mm}$ Luer needle attached to a three-way stopcock which in turn is connected via a tube to a $20 \mathrm{cc}$ syringe containing physiologic saline. After entering an accessible vein, with preference given to a medially located basilic vein or its tributaries, the tourniquet is removed. The injection of the radionuclide bolus is quickly followed by turning the stopcock, and the saline is rapidly injected, propelling the bolus to the right atrium, thus minimising the "lail effect".

Our technique differs from that of Lane in so far as after release of the tourniquet the activity is not injected backwards into the tube containing saline, but the propelling power of the saline injection is used directly after turning the stopcock. When the injection procedure is carefully controlled, variations of the bolus transit closely reflect physiologic variations in blood flow. In about 300 bolus injections in one patient only we noticed an actual division of the bolus into two discernible components. The study of this patient will be demonstrated below (4.6.1. Fig. 25).

Intravenous injection techniques in the antecubital fossa cannot overcome the problem of the thoracic inlet resistance, which often causes the bolus to 
decelerate near the junction of the subclavian veins, probably in the costoclavicular space. Alternative techniques, however, require far more invasive procedures, such as an intravenous catheter connected to an angiographic injector, or a central venous (pressure) catheter (Ashburn, 1971). Invasive techniques are avoided on purpose in our studies to fulfill the simplicity required for a clinical screening technique.

\subsection{Reactive Hyperemia}

The main symptom of arteriosclerosis obliterans is claudication, which occurs during walking, expressing impaired uptake of oxygen accompanied by a delay in removal of metabolites such as lactic acid in the muscle tissues of the leg. Studying the dynamic aspects of peripheral perfusion involves investigating the circulation during physiologic stress of the vasculature as in exercise.

In early experiments we tried to obtain this stress with an external nerve stimulator to provide rhythmic isometric contractions of the calf muscles against a resistance. We found it very difficult to obtain the same work load in each leg and to reach a sufficient and reproducible effect.

Measuring the effectiveness of the circulation under stress conditions requires measurement during vasodilatation. A well known method for inducing vasodilatation is reactive hyperemia. Hishida (1963) stated that the evaluation of the vascular system during maximal vasodilatation of the vessels is indicative of the extremities' reaction to exercise. Reactive hyperemia following arterial occlusion induces a very useful vasodilatation and has advantages over vasodilatation induced by various pharmaceuticals. (Kahn et al., 1965).

As early as 1872 Connheim and Lister investigated the phenomenon of reactive hyperemia following arterial occlusion (Lewis et al., 1925). Originally reactive hyperemia was thought to be the result of vasomotor paralysis of the constrictor nerves, thus being due to a neurogenic cause. However, Bier (1898) demonstrated that after disconnecting the limb from the body except for the artery an equal reaction occurred. Lewis et al. (1925) reported that after releasing the arterial occlusion, the reactive hyperemia occurs with an intensity and during a period directly related to the length of the period of arterial occlusion.

The etiology of reactive hyperemia was investigated by many authors (Hilton, 1962 and 1963; Kahn et al., 1965; Zelis et al., 1969). Many factors like tissue anoxia, carbon dioxide, lactic acid accumulation, release of vasoactive polypeptides such as bradykinin as well as mechanical factors such as reduction in venous pressure were discussed and all appear to play a role. The precise mechanism, however, remains unknown.

Reactive hyperemia appears to be the most reliable method to induce significant vasodilatation. It makes it possible to study peripheral perfusion in the legs under stress for the evaluation of dynamic and adaptic changes in the vasculature. 


\subsection{Gamma Camera System}

Activity-time tracer studies can be performed by a simple radiation detector connected to a rate meter and a suitable chart-recorder. However a gamma camera provided with a data-processing system combines the possibility of imaging with that of dynamic activity curves.

The gamma camera used in this study is the Picker Dynacamera II system (Fig. I) provided with an IVC-video-tape recorder and expanded by the addition of a computer-assisted Image-Enhancement-System (IES). This system consists of a 16K PDP8/E computer, a Teletype, a Tektronix 4010 display terminal, a storage scope, a Polaroid camera scope fitted with computer controlled rotating color filters (for obtaining color-coded Polaroid scintophotos), and a RK8E disk system for data storage. The Dynacamera is a gamma camera consisting of a Thallium-activated NaI-crystal with a $30 \mathrm{~cm}$ effective detecting surface. A parallel hole low energy high resolution collimator is used to obtain a desirable spatial resolution.

When a gamma photon reaches the crystal its quantum energy is converted to a light flash within a microsecond. The light induces photoelectric pulses in the photomultipliers behind the crystal. The amplified and summed electronic pulses are proportional to the energy transfer of the quantum in the crystal.

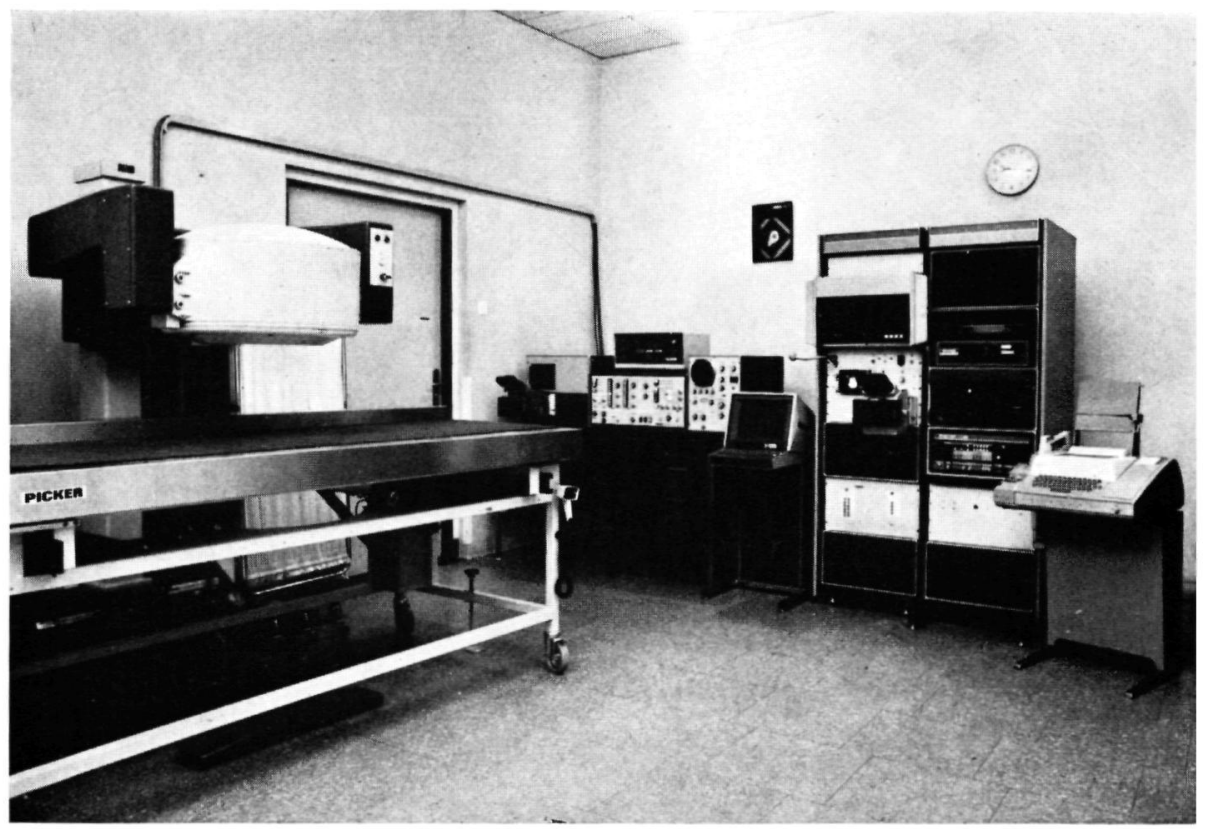

Fig. 1: The gamma camera system used in this study. 
All the data of the camera can be converted to a digital mode and stored in the memory of the PDP8/E computer or recorded on video-tape.

The stored information can be processed by the built-in data processor of the camera system or alternatively handled by the computer-assisted system. Scintiphotos of the activity distribution image can be obtained at any desired time interval. Also activity versus time curves can be obtained for any selected area of interest.

\subsection{Processing and Display}

The programs utilized for data processing with our Dynacamera system are described in detail by Hasman and Groothedde (1972, 1973). Two main programs are employed for the purpose of this study:

a) Image Enhancement Program.

b) Activity time analysis of selected areas of interest.

The image enhancement program permits the display of activity intensity ranges expressed in a spectrum of 8 equal intervals of color. The useful color spectrum is set between the warmest and coolest color by adjusting three parameters controlling the following factors:

1. Cut-off level: High activity counts are cut out by setting a cut-off point within the range $0-100 \%$ of the maximum counts that can be registered.

2. Saturation level: The level of the warmest color is set anywhere between 0 and $100 \%$ of the pre-determined cut-off value.

3. Background suppression: The level of the coolest color is set anywhere between 0 and the saturation level.

Any area within a matrix of $100 \times 100$ picture elements covering the total detector area can be selected for activity-time analysis. In the dynamic mode activity data are accumulated in one hundred time increments, each of one second duration. For the selection of areas of interest the activity data at any desired interval from $0-100$ seconds are visualized on the memory scope. Through the display terminal the selected area of interest is defined by typing the appropriate $X$ and $Y$ coordinator numbers. After selecting the desired areas of interest the program is activated to display the requested activity-time curves of the different regions of interest. Each activity curve corresponding to any area of interest is identified by a color related to the serial number of the region of interest. Individual activity counts for each time increment (1 second) for each region of interest can be printed out through the Teletype. 
Similar histograms can be obtained in black-and-white Polaroid photos through the built-in 100 channels data processor. This latter system, however, is limited to two areas of interest at one time, whereas the computer program is capable of generating several areas of interest simultaneously, up to a maximum of 12 areas.

Due to difficulties in reproducing color coded scintiphotos, the pictures included in this thesis are represented as closely as possible in black-and-white grey shades.

\subsection{Procedure Details}

The investigation is performed under normal conditions of room temperature, barometric pressure and humidity. There was no rest period nor any special preparation of the patient. The subject lies face down on the examination couch, and the detector of the gamma camera is placed over the calves of both legs.

A conical thigh cuff is applied to each thigh above the knee joint. With the cuff proximally placed around the thigh, the result of release of the cuff is maximal vasodilatation of nearly the whole upper and lower leg. Normally the profunda femoris artery supplies the thigh tissues, while the calf tissues are supplied by the superficial femoral artery. To avoid competitive interaction of both compartments with cuffs on varying levels of the thigh, the

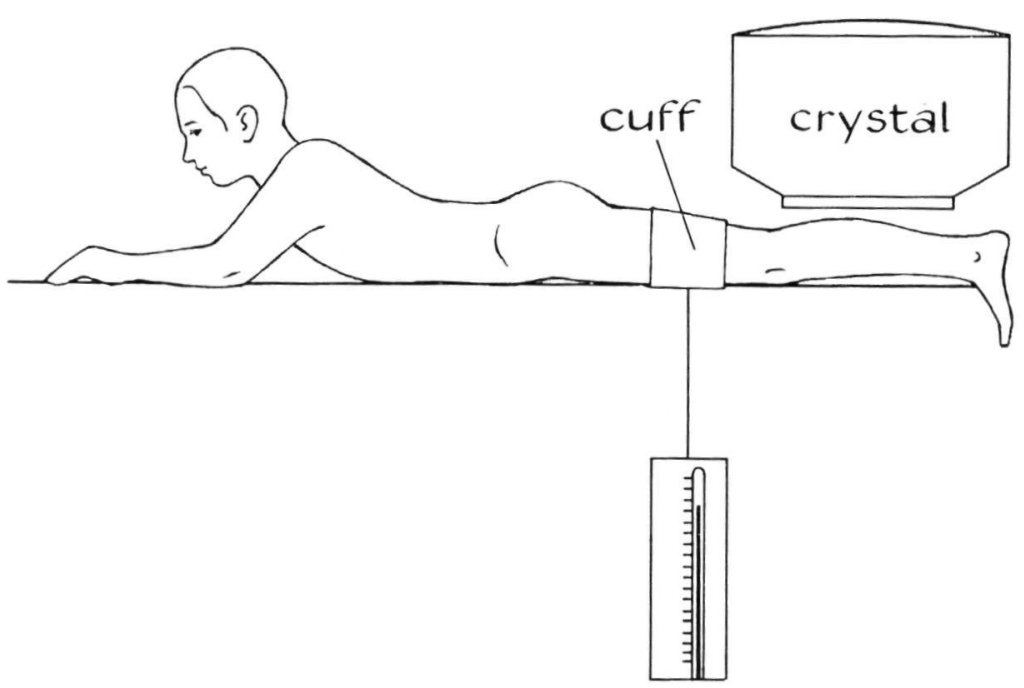

Fig. 2: Diagrammatic illustration of the patient set-up. 
technique was standardized with the cuffs placed close to the knee joint level. The main purpose is to obtain maximal perfusion of the calf tissues in normals and in patients with arteriosclerosis obliterans. This is because most of the symptomatology of the disease is related to claudication complaints in the calf, and also because present surgical reconstructive techniques end at the tibial artery level.

Both cuffs are attached via rubber tubing and "Y"-connectors to each other to obtain equal pressure regulation. The manometric pressure is raised $50-100$ $\mathrm{mm} \mathrm{Hg}$ above systolic pressure (Fig. 2). The resulting ischemia is maintained for a period of 5 minutes, including two minutes of active muscular exercise, consisting of moving the feet at the ankle joint against the resistance of a metal plate at the end of the couch. This results in a state of maximum hyperemia after release of cuff pressure.

If the patient complains of intolerable pain during ischemia, the pressure is immediately released and the radionuclide bolus is rapidly injected. This consists of $8 \mathrm{mCi}$ of ${ }^{99 m}$ Technetium-pertechnetate in a volume of $0.8-2.5 \mathrm{ml}$. The injection is given into a medially located vein (if possible), in the antecubital fossa through a $1.2 \mathrm{~mm}$ Luer needle according to the technique mentioned above (2.4).

The arrival and distribution of the radioactivity in both calves are observed on the monitor scope of the gamma camera and simultaneously recorded in the digital mode on video-tape or on disk. The total recording time is 100 seconds. The earlier studies were confined to the perfusion of the calf tissues, evaluating, with small regions of interest, differences in perfusion of proximally and distally located calf muscles.

In later investigations the position of the detector of the gamma camera was modified, placing it $10-15 \mathrm{~cm}$ more proximally, such that the greater part of the calf and most of the distal part of the thigh muscles were included. Selected regions of interest make it possible to compare the activity distribution and activity turnover in the areas perfused by different arteries of one leg. Furthermore the opposite extremity simultaneously acts as a control for the extremity under investigation. This is an advantage of the "comparative" technique as suggested by MacIntyre et al. (1952).

\subsection{Arteriographic Technique}

Some of the arteriographies were aortograms obtained by percutaneous retrograde catheterization and some by translumbar aortic puncture. In some cases where the distal arterial tree was not optimally visualized, additional femoral angiograms by direct puncture of the femoral artery were required.

Approximately $50 \mathrm{ml}$ of a $65 \%$ Angiografin $^{\otimes}$ solution (N,Methylglucamin salt of N,N-diacetyl - 3,5 diamino - 2,4,6 triiodobenzoïc acid) were injected twice. After the first injection serial films of the femoro-popliteal segments 
were taken, and after the second injection the lumbar aorta and the pelvic arteries were visualized.

Utilizing this technique the popliteal artery was commonly visualized, but the lower leg vessels were not always clearly outlined. An aortogram was accepted as reflecting the current condition of the vascular system of the patient if the clinical status demonstrated no change during the time interval (usually 1-2 months) between the angiogram and the tracer study. 


\section{SUBJECT MATERIAL}

\subsection{Main Groups}

The subject material investigated is this study is divided into two major groups. GROUP A consists of 28 normal subjects (56 legs) without clinical evidence of vascular disease. Arteriography was not justifiable and hence not performed on any individual in this group. There were 23 men and 5 women, ranging from 17 to 61 years of age (mean age 40.6 years with a standard deviation of 12.2 years).

GROUP B consists of 104 patients with claudication complaints, all of whom were submitted to arteriographic examination. Of the total number 95 were men and 9 women, ranging from 32 to 81 years of age (mean age 59 years with a standard deviation of 11 years).

\subsection{Arteriographic Interpretation}

A classification of occlusive patterns based on anatomic interpretation of the femoral angiogram was presented by Haimovici (1960). He described 9 different angiographic patterns of occlusive disease of the femoro-popliteal segments and 3 collateral circulation patterns. He also observed the presence of "run-off", when the distal popliteal artery segment and its branchings were visualized. He pointed out the difficulty of evaluating the efficiency of any collateral circulation according to arteriographic findings. This is due to the difficulty in correlating functional significance of collaterals to their number rather than their size. The extent of the occlusion as well as the presence of re-entry in the arterial channel can provide a fair indication of the collateral artery function.

The presence of adequate outflow, i.e. run-off distal to the occlusion site, is the most decisive factor in the selection of patients for arterial grafting or thromboendarterectomy.

Patients displaying a complete block of the distal popliteal artery and its trifurcation are generally not suitable for such procedures. Hence proper evaluation of arterial disease of the lower leg includes the study of the tibial 
vessels and the distal popliteal artery segment The prognosis of the arterial disease will ultımately depend upon the degree of involvement of these artenes

One of the objectives of a tracer study such as presented in this thesis is to correlate the obtained results with the findings provided by angiography One should realize, however, that angıographic patterns provide anatomic information of the occlusive disease, whereas a tracer study provides information of the impaired hemodynamics due to the occlusive process

\section{Arteriographic Classification}

For practical reasons simplification of the angıographic classification as reported by Haimovici (1960) was necessary The presence and extent of stenosed and occluded vascular segments as well as the presence of "run-off" were used as criteria for the arteriographic patterns In the claudicant group the legs accordingly were divided into 5 subgroups (Table I)

rable I Subgroup classification correlated to Arterıgraphic diagnosis

$\begin{array}{ll}\text { Subgroup I } & \text { Patent arteries } \\ \text { Subgroup II } & \text { Stenosis in a single vascular segment } \\ \text { Subgroup III } & \text { Occlusion of a single vascular segment } \\ \text { Subgroup IV } & \text { Occlusion or stenosis in multıple vascular segments } \\ \text { Subgroup V } & \text { Poor run-off }\end{array}$

Subgroup I includes "patent" arterıgraphic pattern, i e when there is no occlusion or stenosis as well as good run-off in all parts of the vasculature This includes diffuse arteriosclerotic changes of the vessel walls, provided that the vascular lumen is reduced by less than 50 percent In the other subgroups there are varyıng degrees of vascular stenosis or occlusive disease, regardless of the anatomical site of the diseased segment except in subgroup $V$

Defined as belonging to subgroup $I I$ were all the legs with an angiographically confirmed stenosis in a single vascular segment A stenosis was present when there was a narrowing of the vascular lumen by 50 percent or more

Defined as subgroup $I I I$ were all the legs with an angiographically confirmed occlusion of a single vascular segment

Defined as subgroup $I V$ were all the legs with angıgraphically confirmed occlusions or stenosis in multiple vascular segments

Defined as subgroup $V$ were all the legs with severe vascular disease located 
at the run-off vessels. This includes stenosis or occlusion of the distal part of the popliteal artery below the knee as well as occlusion in two or more tibial arteries or serious arteriosclerotic irregularities with multiple stenosis in these leg arteries. These findings may or may not be accompanied by occlusive disease in other vascular segments.

There exists an inverse relationship between the increasing degree of vascular disease in the distal segment and the possibility of arterial grafting procedures or thromboendarterectomy.

\subsection{Relation of subgroups to patient group}

As mentioned above the subgroups are composed of legs and not of patients. Every subgroup is considered as representative for a hypothetical population of legs with the same characteristics. As a consequence there are patients with each leg in a different subgroup and others with both legs in the same subgroup. Investigated were out patients referred to the hospital because of claudication complaints in the period of November 1972 - November 1974.

\subsection{Incidence of anatomic localizations}

In the patient group was an incidence of occlusions in the aorto-iliac segment of $7 \%$ (11 out of 155 ). In agreement with the concept that the initial localization of the occlusion starts at the adductor magnus foramen, most of the occlusions i.e., $62 \%$ were found in the superficial femoral artery (96 out of 155). Leriche (1947) reported an occlusion rate of the superficial femoral artery of $68 \%$ (90) out of 133), Mavor (1956) of $85 \%$ (121 out of 142), and Haimovici (1960) reported a superficial femoral artery involvement rate of $55 \%$ ( 75 out of 137 ).

Occlusion of the popliteal artery was observed in our material in $18 \%$ (28 out of 155). Leriche and Mavor both reported an incidence of $11 \%$.

Another frequent localization of lesions is in the tibial artery system of the calf, most commonly seen in patients over sixty years of age as well as in diabetic patients. Frequently these lesions are associated with lesions of the aorto-iliac or femoro-popliteal arteries as well. Occlusion of all the lower leg arteries was found only in $5 \%$ of the cases and occlusion of two or more arteries of the tibial artery system was observed in $18 \%$. Haimovici found a very high incidence of total occlusions of the lower leg arteries $(43 \%)$ as well as occlusion of two or more arteries (38\%). In his material only half of the patients displayed a good run-off. However, in his material there was a high percentage of diabetics, and a poor run-off was reported to be as twice as high in diabetics as in non diabetics. Watt (1963), excluding patients with aorto-iliac disease, reported in $40 \%$ (213 out of 528) femoro-popliteal disease. He demonstrated in $32 \%$ femoro-popliteal disease as well as occlusive disease of the lower leg arteries, whereas $14 \%$ had an occlusion of the lower legs alone. 
As mentioned above only GROUP B patients underwent arteriography, hence providing an objective classification in the 5 different subgroups. After treatment in most of the patients no control angiogram was performed. As a result an objective classification after surgery is not available.

The patient group underwent two tracer studies, one before and one after treatment. In some cases a second study was not performed merely due to inoperability or a very poor general condition of the patient precluding further evaluation.

Excluded from the material were patients suffering from decompensating heart disease or other serious central circulatory disturbances such as mitral valve disease. The pathologic central transport of the activity bolus might otherwise interfere with the transport to the lower leg. 


\section{PATTERN ANALYSIS AND CLINICAL INTERPRETATION OF THE TRACER TEST}

\subsection{Introduction}

The tracer technique introduced in this thesis offers two sets of data for each investigation. One set consists of color-coded scintiphotos imaging the activity distribution in the regions of the legs under study. The other set consists of activity curves for any selected area of interest in each leg. The clinical interpretation and analysis of these data are the subject of this chapter.

\subsubsection{The normal pattern}

In normal subjects under reactive hyperemia the time-activity curves demonstrate a typical pattern and the scintiphotos show regular symmetrical activity distribution (Fig. 3a and b). The normal activity curve consists of two

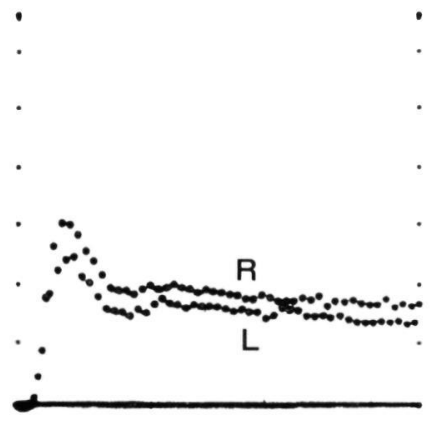

17า

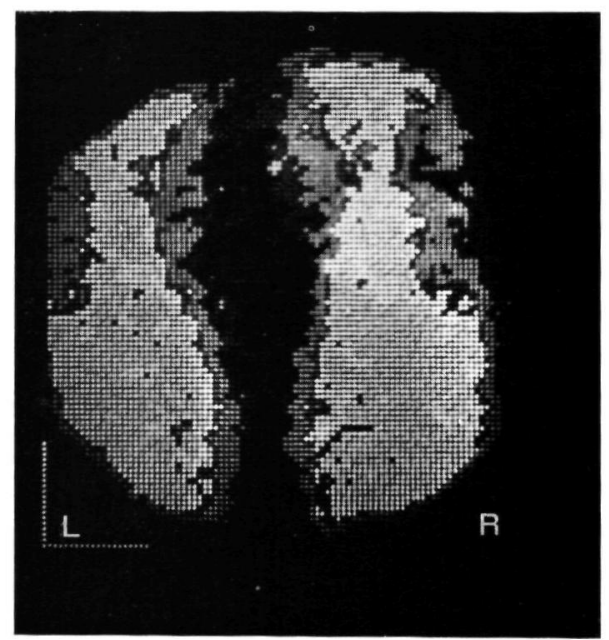

Fig. 3a: Normal curve pattern.

Fig. 3b: Black-and-white reproduction of color-coded scintiphotos with normal symmetrical activity distribution. 


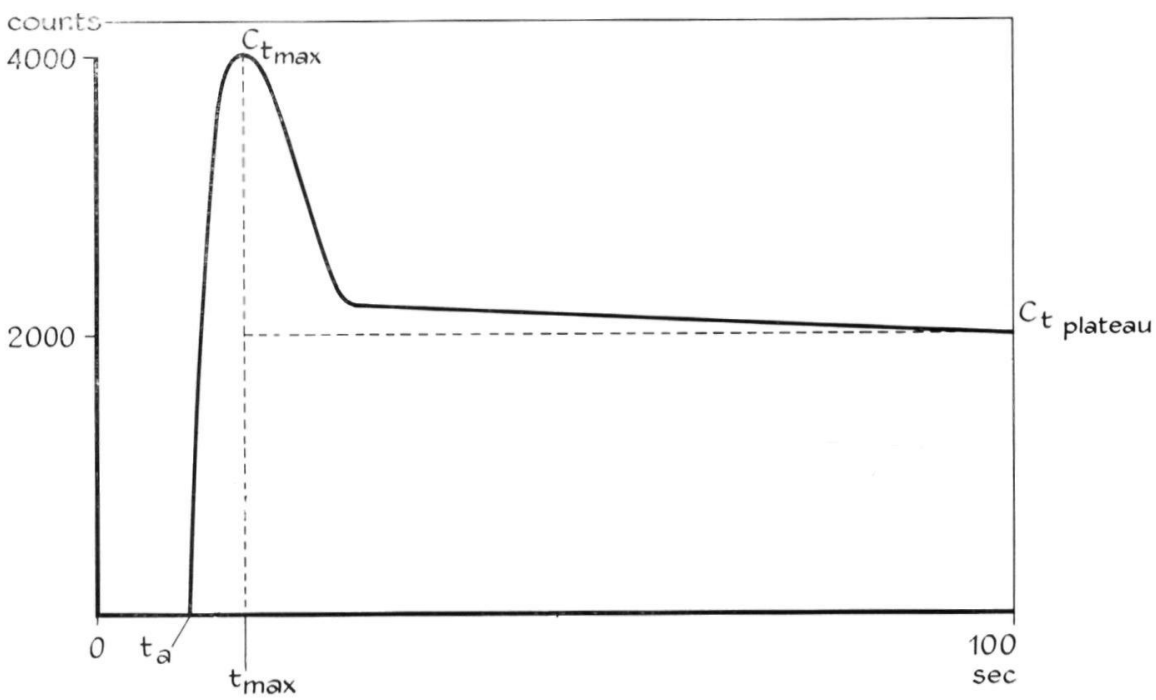

Fig. 4: Graphic representation of a typical normal curve.

segments: a peak segment and a plateau. An average of 9 seconds following the injection (range 7-12 sec) is required before the first appearance of activity in the calf muscles is recorded (Fig. 4). This arrival time is symbolized as $t_{a}$. The time needed to reach peak activity is referred to as $t_{\max }$ and is calculated as the difference between the arrival time $t_{\mathrm{a}}$ and the time at which the maximum

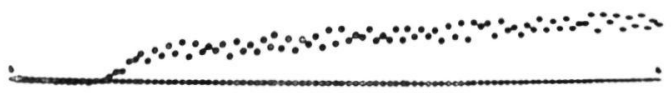

1717171717

IIIIIIIIII

Fig. 5: Flat curve obtained under resting conditions. 
count rate is registered. The mean $t_{\mathrm{m} d}$ is 8 seconds (range 5-13 sec). After reaching a peak the normal activity curve descends to a plateau representing equilibrium. Under normal conditions the activity curves of both legs are so similar that one can be superimposed on the other.

The peak segment of the normal curve can be obtained only under conditions of maximum reactive hyperemia. When the test is performed at rest a flat curve is obtained (Fig. 5).

The typical pattern of the normal curve lends itself to a mathematical relationship that can be used as a parameter for the evaluation of functional peripheral vascular patency. This parameter is called perfusion index (P.I.) and is defined as the ratio of counts on the peak of the activity curve to the counts on the tail of the plateau at equilibrium ( 99 seconds), i.e.:

$$
\begin{aligned}
\text { P.I. }= & \mathrm{C}_{\mathrm{t}_{\text {max }}} \\
& \mathrm{C}_{\mathrm{t}_{\text {plateau }}(99 \mathrm{sec})}
\end{aligned}
$$

The mean normal P.I. value is 1.74 (range $2.2-1.3$ ).

\subsubsection{Physiologic interpretation}

The peak segment of the curve obtained during maximal vasodilatation corresponds to the activity transport through patent main vessels to the dilated vascular bed of the leg muscles, while the plateau corresponds to the equilibration of intra- and extravascular activity of the diffusible tracer. The normal peak segment of both legs demonstrates only minor differences in shape as well as height. Also both plateaus representing equilibrium activity are normally similar. Slight asymmetry in volume or position of the legs under the detector of the gamma camera may cause a small difference in height of two parallel curves (Fig. 3a).

\subsubsection{Early pathologic changes}

When the peak activity in one leg is decreased and the scintiphotos demonstrate diminished activity distribution as compared to the opposite side, a stenotic part in the main vascular tree is suspected. Fig. 6 (a and b) shows a

Fig. 6a: Black-and-white reproduction of color-coded scintiphotos of normal right calf and pathologic left calf.

Fig. $6 b$ : Normal right curve pattern; lower peak of curve corresponding to left leg

Fig. $6 c$ : Arteriographic study of the same patient. Note the stenosis in the left superficial femoral artery indicated by arrow. 

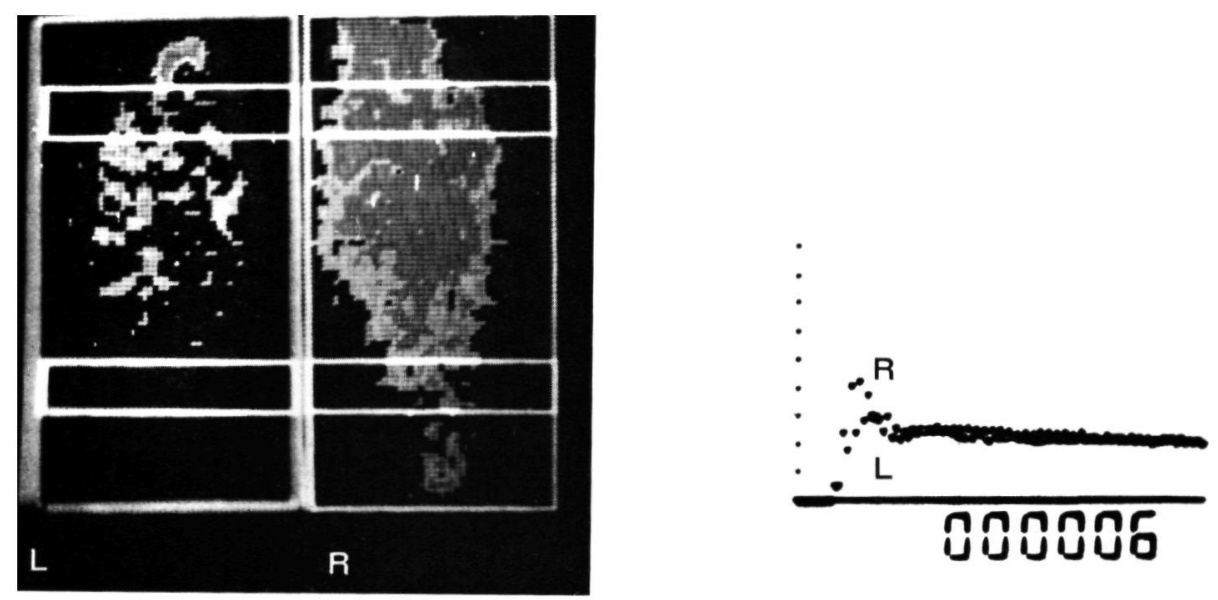

R

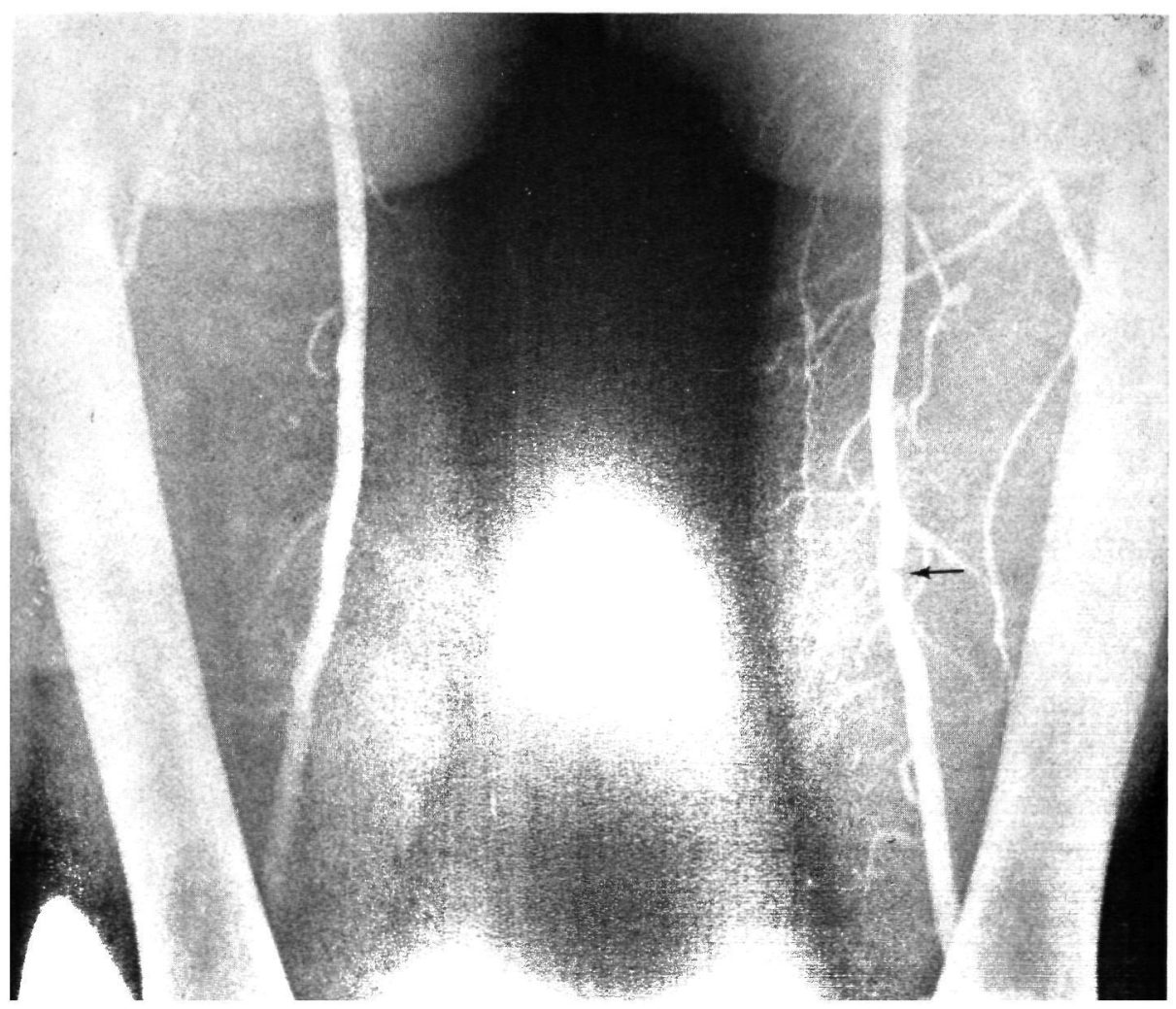


tracer study illustrating such an example. Angiographic confirmation is presented as well in Fig. 6 (c).

\subsubsection{Clinical interpretation}

The atherosclerotic process with the formation of intimal plaques and intimal thickening has a tendency to reduce the vessel lumen. As a result the passing of the tracer bolus as represented by the peak activity will be partially delayed. In the example shown in Fig. 6 it is obvious that the obtained curves are not similar. This indicates the sensitivity of the method demonstrating the effect of only a small but significant stenosis on the peak segment as well as on the activity distribution in the affected leg. The plateau is not influenced.

\subsubsection{The pattern in obstructive disease}

The pattern of activity curves in patients with occlusive disease is different from the normal pattern. The most significant feature is the absence of the activity peak. Fig. 7 illustrates the tracer study and Fig. 8 the arteriogram of a patient with occlusion of the left common iliac artery.

The pathologic curve has two components, one fast and one slow. The fast component starts at $t_{\mathrm{a}}$ and ascends to join the plateau of the slower component.
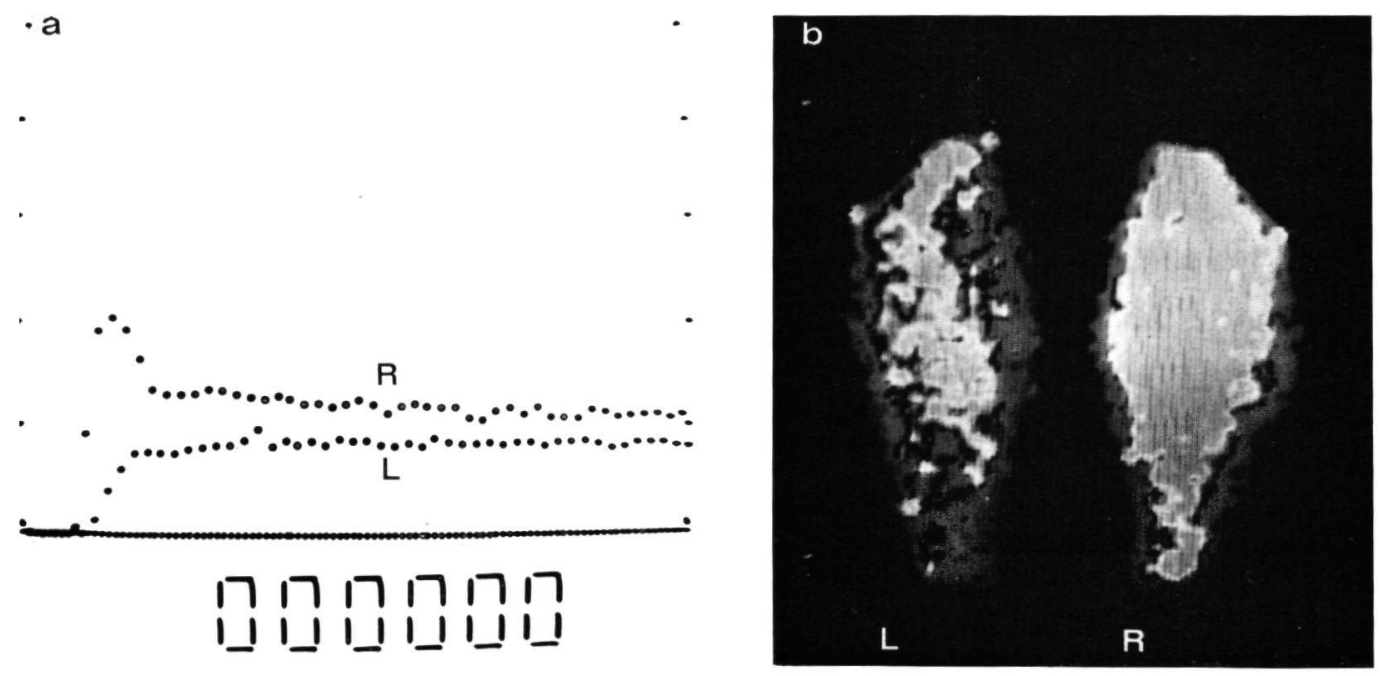

Fig. 7a: Pathologic curve pattern of the left leg. Note absence of peak and horizontal plateau.

Fig. 7b: Black-and-white reproduction of a color-coded scintiphoto of the same study. 


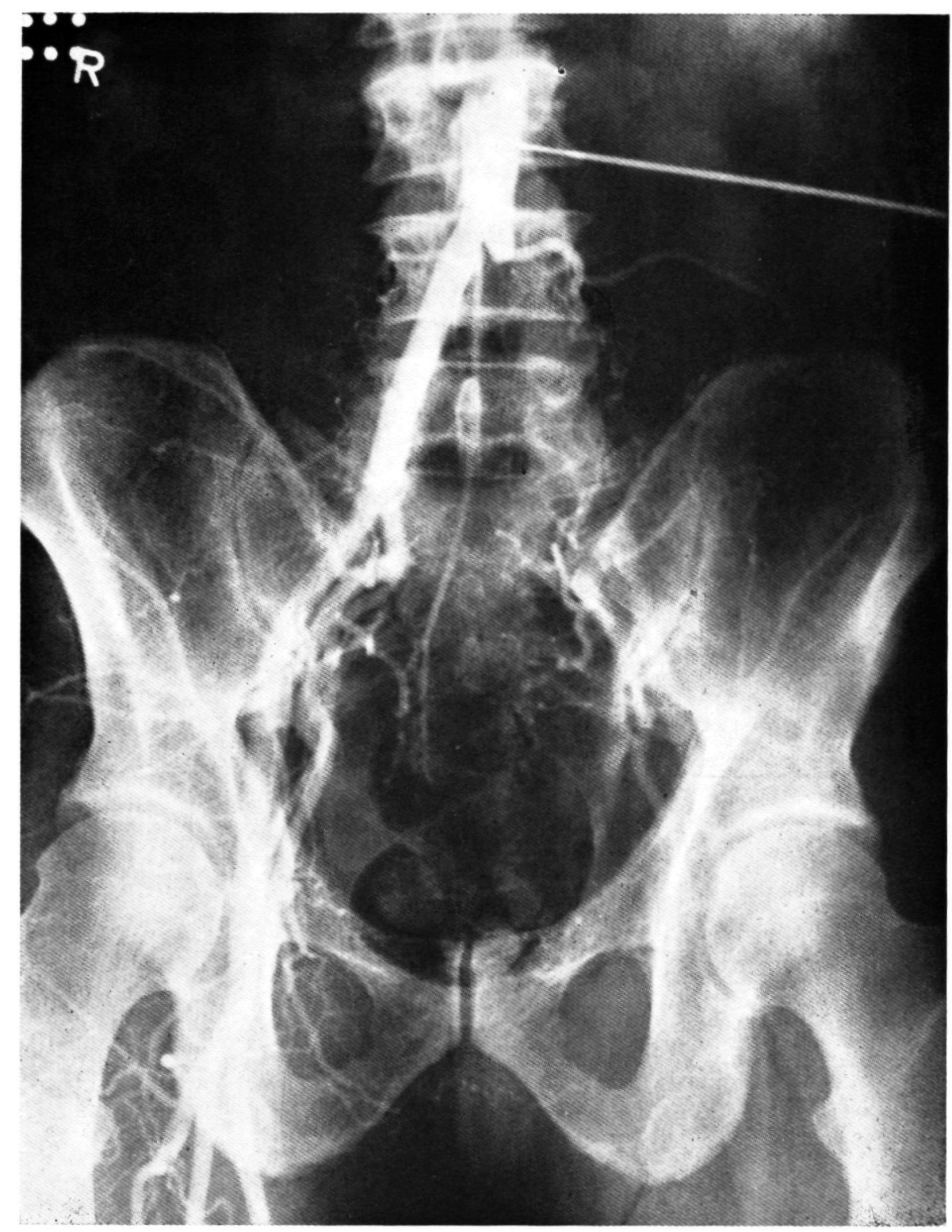

Fig. 8: Arteriogram of the same patient as in Fig. 7, demonstrating occlusion of the left common iliac artery. 


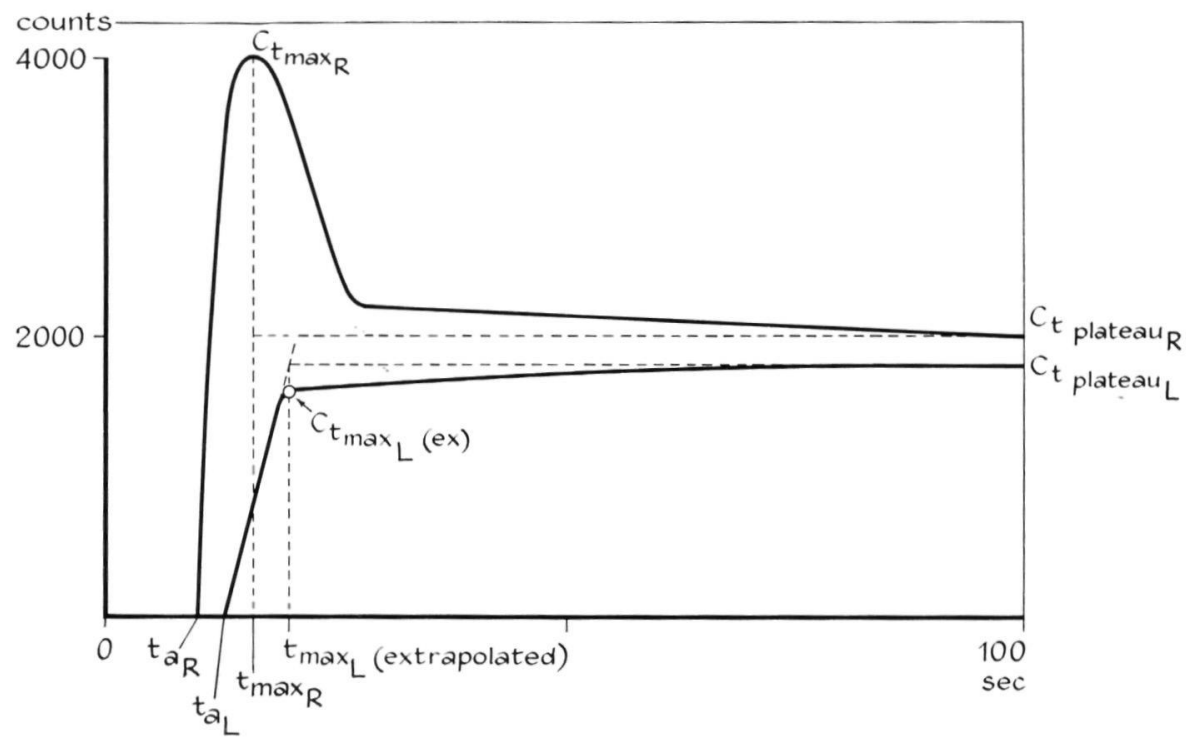

Fig. 9: Diagrammatic explanation of the normal (right) and pathologic (left) curve analysis. Note the extrapolated $t_{\max }$ and $C_{t_{\max }}$ on the curve of the left calf. The plateau is ascending.

In order to define the perfusion index in the pathologic curve, the counts at $\mathrm{t}_{\max }$ are extrapolated by drawing a horizontal line from the point of maximum counts on the curve to the tangent of the slope of the fast component (Fig. 9). The point at which the two lines meet, projected on the time scale, is $t_{\max }$. The P.I. is then defined as the ratio of counts at the extrapolated $t_{\max }$ to counts on the tail of the plateau at equilibrium (99 seconds).

The plateau can be of three types:

a) Horizontal (P.I. $=1.0$ ); this denotes unchanged equilibrium activity during the recording period.

b) Ascending (P.I. $<1.0$ ); here the plateau describes a gradual upward slope due to prolonged transport of activity before reaching equilibrium.

c) Descending (P.I. $>1.0$ ); here maximum activity is reached at the end of the fast component despite the absence of a true peak. Thereafter the curve gradually descends to reach the equilibrium level (Fig. 10).

As shown in Fig. 7, the level of the plateau of the affected leg is obviously low compared to the opposite side. When asymmetry of position of the legs is excluded, this finding might indicate a decreased intra- and extravascular volume on the affected side. The ratio between the two plateau levels is termed the Plateau Ratio (P.R.). The normal Plateau Ratio is 1.0 (range $0.8-1.2$ ). 

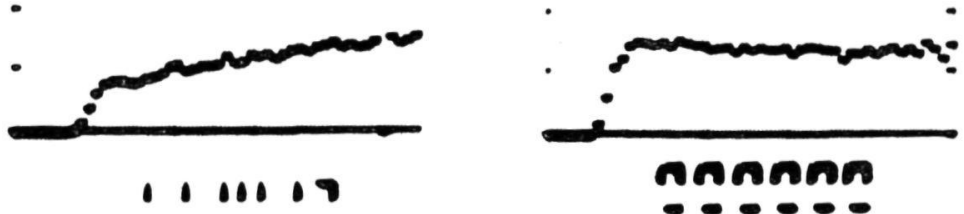

กตรกตก

$-\bullet-0$

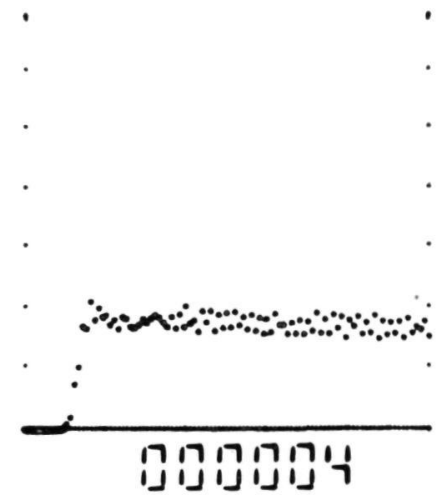

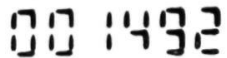

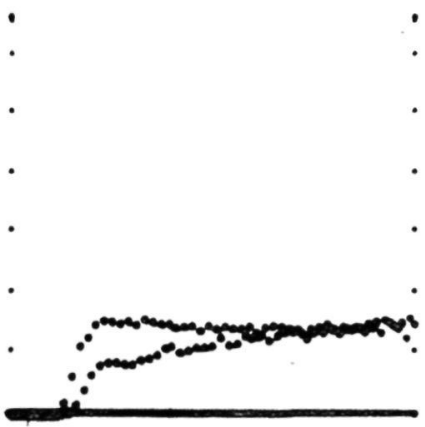

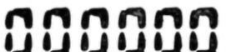

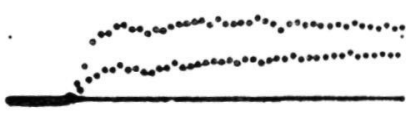

ד17. רו רי

עיגנעיניגיני

Fig. 10: Different pathologic curve patterns showing the 3 types of plateau (ascending, horizontal and descending). 


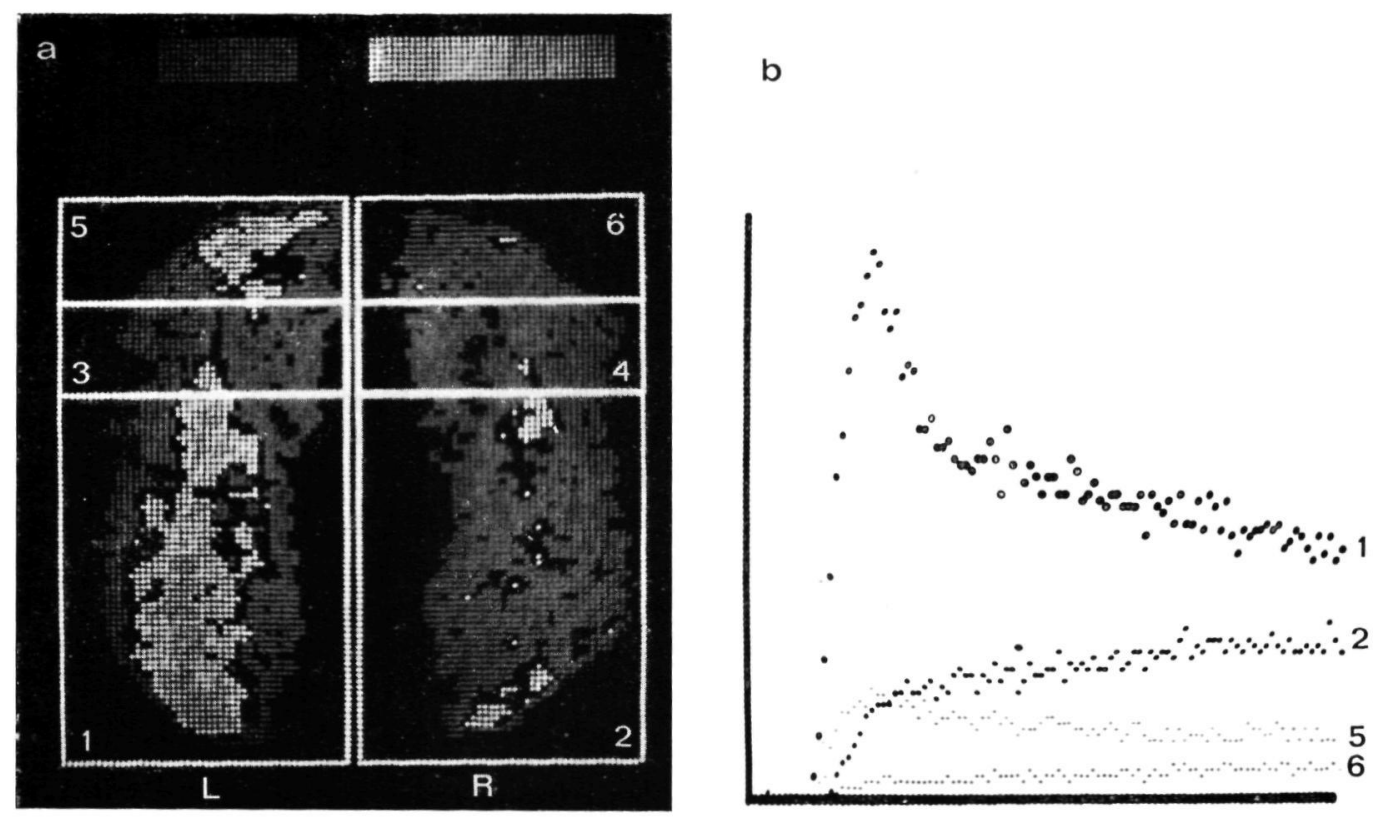

Fig. 11a: Black-and-white reproduction of color-coded scintiphotos with areas of interest. 1 and 2: covering left and right calf; 3 and 4: covering left and right popliteal fossa; 5 and 6 : covering left and right thigh.

Fig. 11b: Activity-time curves for area 1, 2, 5 and 6.1 and 5 are normal curves obtained from the left leg; 2 and 6 are pathologic curves obtained from the right leg. This suggests occlusion in the aorto-iliac artery segment.

Fig. 12a: Black-and-white reproduction of color-coded scintiphotos obtained during the first 20 -second-interval of the injection from the right and left leg. Note the poor activity distribution below the thigh on the left side.

Fig. 12b: Scintiphotos of the same patient during the last 20 seconds of the study with areas of interest (plateau period).

Fig. 12c: 3 Curves obtained from the 3 regions covering right calf, popliteal fossa, and thigh. Note the normal pattern.

Fig. 12d: Corresponding curves obtained from the left leg. Calf and popliteal fossa curves are pathologic.

Fig. 12e: Both normal curves obtained from the regions covering left and right thigh.

Fig. 12f: Composite of right and left calf and popliteal curves, contrasting the normal and pathologic curve patterns. 


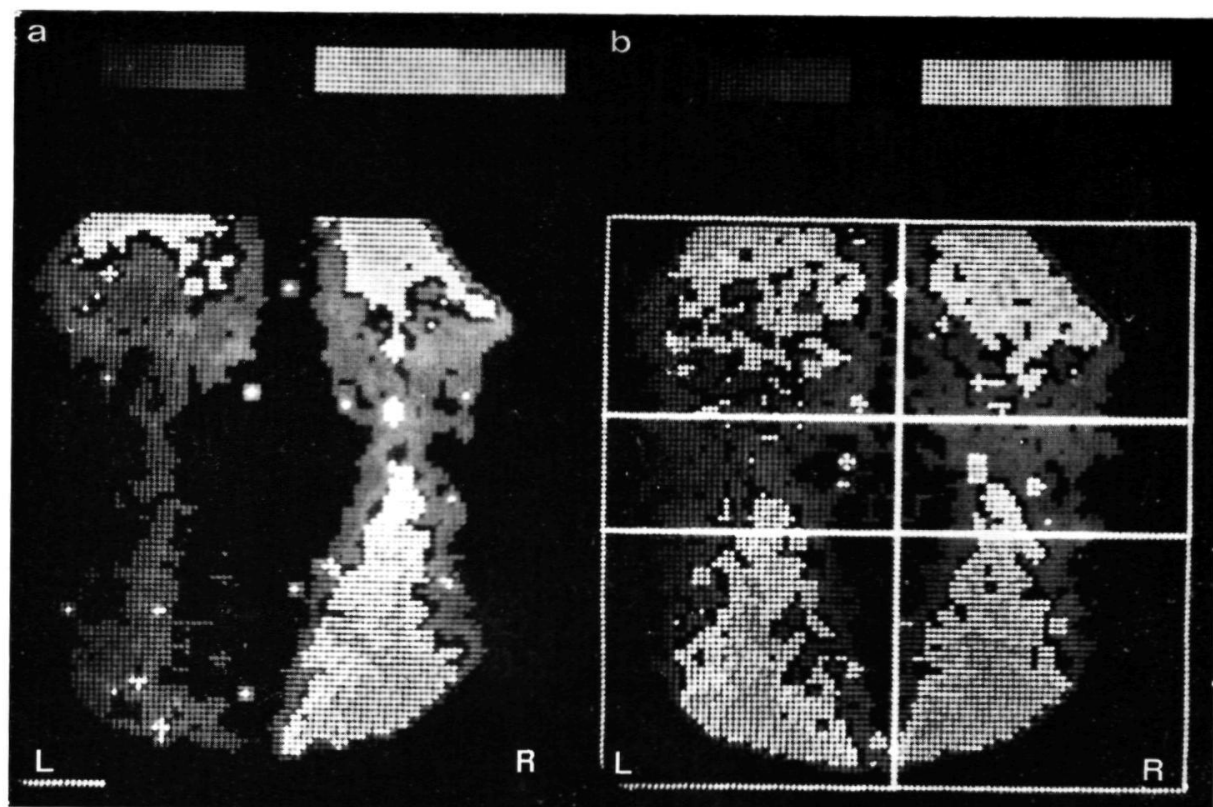

C

d

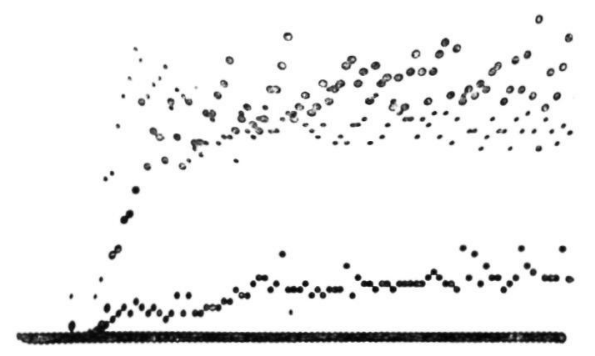

e

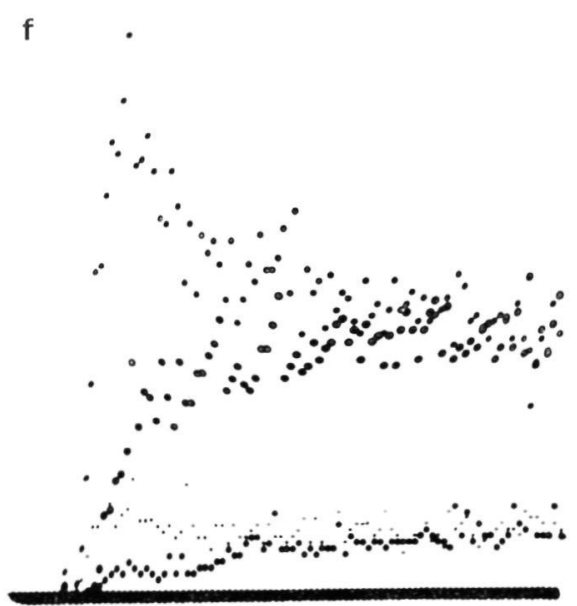


It is possible to differentiate between an aorto-iliac obstruction above the inguinal ligament and a femoro-popliteal occlusion below the inguinal ligament. Theoretically there are four possibilities:

a) Occlusion above the bifurcation of the common femoral artery. As a result, distal to the obstruction there is poor perfusion of the profunda femoris artery and the superficial femoral artery. The time activity curves of two regions of interest covering the thigh as well as the calf separately will both demonstrate pathologic curve patterns with absent peak activity (Fig. 11).

b) Obstruction distal to the common femoral artery in the femoro-popliteal segment, but with a patent profunda femoris artery. In this condition a normal curve pattern will be obtained from the area covering the distal thigh and a pathologic one from the calf region (Fig. 12).

c) Obstruction of the profunda femoris artery. A single obstruction of the profunda is very rare and not demonstrated in this material. It would be easily demonstrated, however, as poorly perfused distal thigh muscles with pathologic curve pattern and normal perfusion of the calf muscles.

d) Occlusion, both of the superficial femoral artery and the profunda femoris is difficult to differentiate from aorto-iliac obstruction. Obviously when there is obstruction in the aorto-iliac segment, it is not possible to diagnose a more distal occlusion in the femoro-popliteal segment as well.

As demonstrated above the three chosen areas of interest in each leg have greatly enhanced our ability to predict the site of the obstruction. The arrival and distribution of the activity is studied with images taken shortly after the first appearance until 25-30 seconds after injection.

\subsubsection{Indications of pathologic run-off}

On the serial scintiphotos not only main channel occlusion can be detected, but also run-off pathology. This is demonstrated as localized inhomogeneous distribution of activity with multiple areas of decreased perfusion.

The interpretations described above can be illustrated by the tracer study of a 73-year-old man with serious claudication complaints in both calves after a walking distance of 20-30 meters. The images of activity data at 18 seconds interval after the intravenous injection demonstrated main channel occlusion. In subsequent scintiphotos taken at 24 and 30 seconds intervals, multiple areas of irregular activity distribution in both calves were seen due to poor run-off (Fig. 13). The curve patterns obtained from both thigh regions demonstrated low peak activity. Pathologic curve patterns were obtained from both calves, suggesting occlusive disease in the femoro-popliteal segment (Fig. 

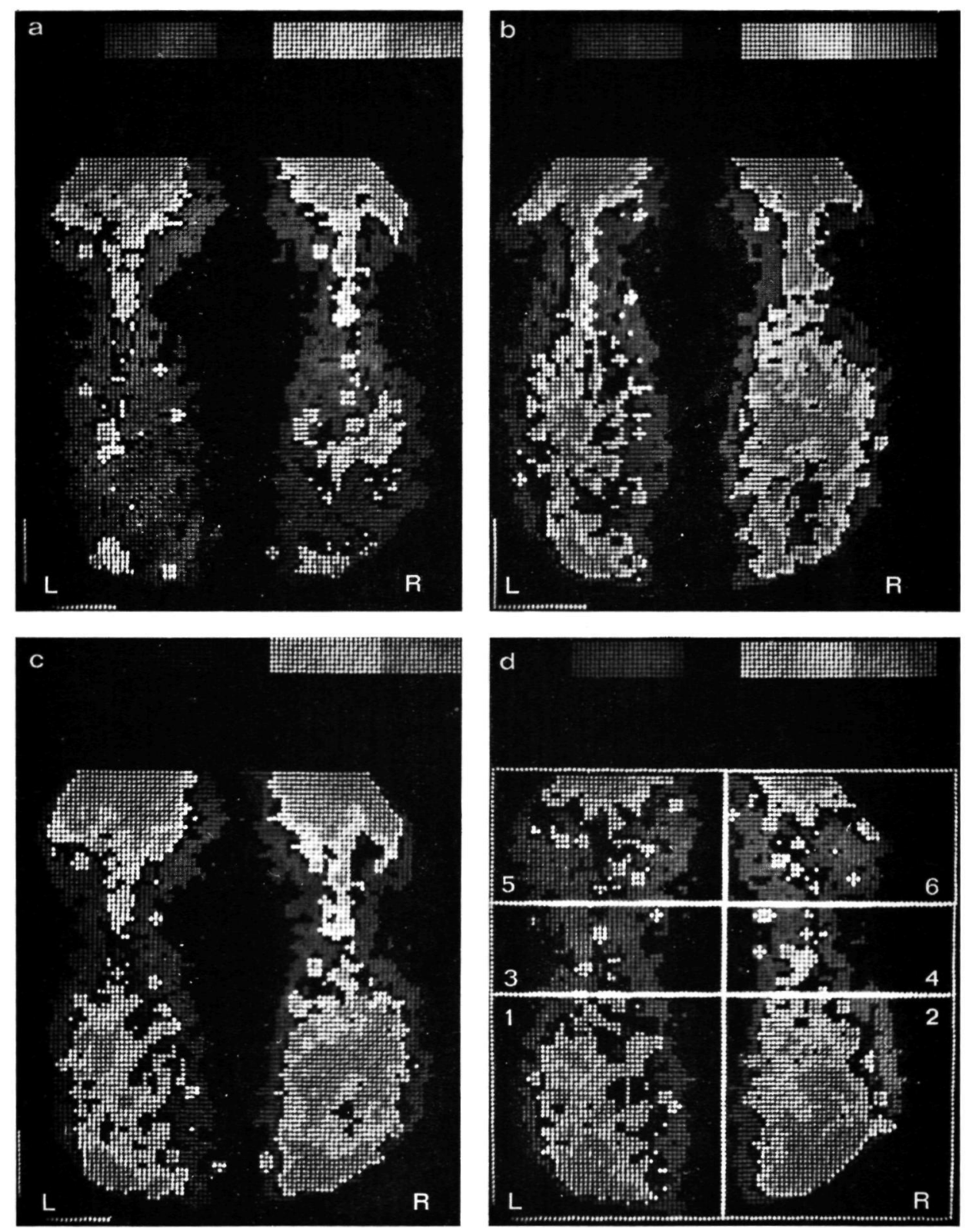

Fig. 13: Serial scintiphotos of a patient with claudication complaints and poor run-off: a: 18 seconds interval after injection - b: 24 seconds interval after injection - c: 30 seconds interval after injection - d: 100 seconds interval after injection with regions of interest shown. 


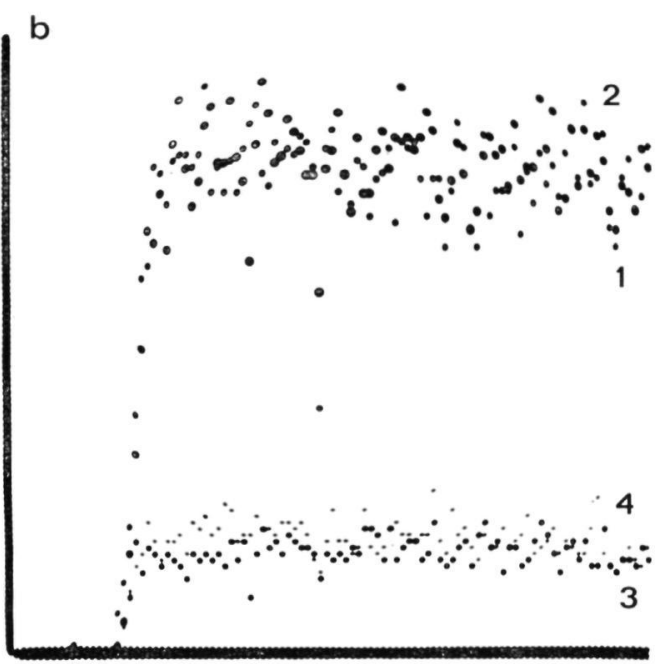

Fig. 14a: Activity-time curves of areas of interest covering boths thighs (no 5 and 6).

Fig. 14b: Activity-time curves of areas of interest covering both calves (no 1 and 2) and both popliteal fossae (no 3 and 4).

14). These findings were reported as bilateral occlusion of the superficial femoral artery and probably arteriosclerotic disease of the tibial artery system with irregularly decreased calf perfusion. The angiogram confirmed the diagnosis of main artery occlusion in the femoro-popliteal segment on both sides and furthermore demonstrated irregular arteriosclerotic changes in lower leg arteries (Fig. 15).

The angiogram can only demonstrate the origin of the tibial and peroneal arteries, while the tracer study reflects local areas of poor perfusion probably due to arteriosclerotic disease of the smaller non-visualized muscular branches as well. Assessment of poor run-off will be even easier in advanced small vessel disease with occlusion of tibial arteries. In elderly patients this will almost invariably be accompanied by occlusion of the main artery as well.

As a result the perfusion of the calf and foot will be very poor as may be illustrated by the following case of a 71-year-old man with a 2 month history of pain in both calves after walking 50 meters. He also complained of nocturnal paresthesia and pain in the right leg. Clinically there were no pulsations below the femoral artery. Furthermore there were dystrophic changes in the feet but no ulcerations. The results of the tracer study are shown in Fig. 16. The curve obtained for the right leg demonstrated a slight delay in arrival time with a very slowly rising component reaching a low plateau compared to the left side. Gamma camera images obtained 40 seconds after arrival of the activity in the leg showed very poor perfusion of the right leg muscles. The P.I. values were 1.1 on 


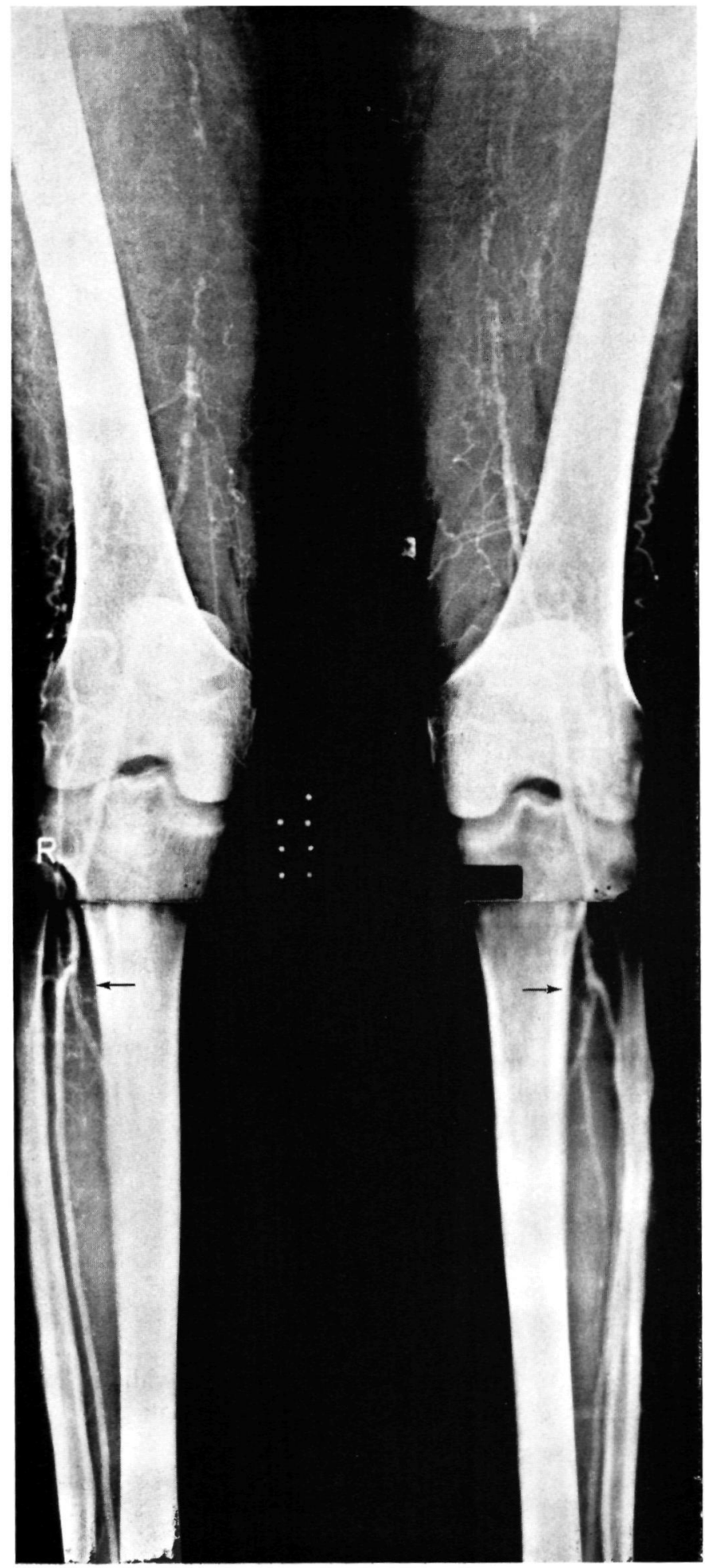

Fig. 15:

Angiogram of the same patient as in Figs. 13 and 14.

Note occlusions of both superficial femoral arteries and arteriosclerotic

changes with stenosis of the tibial artery systems,

indicated by arrows. 

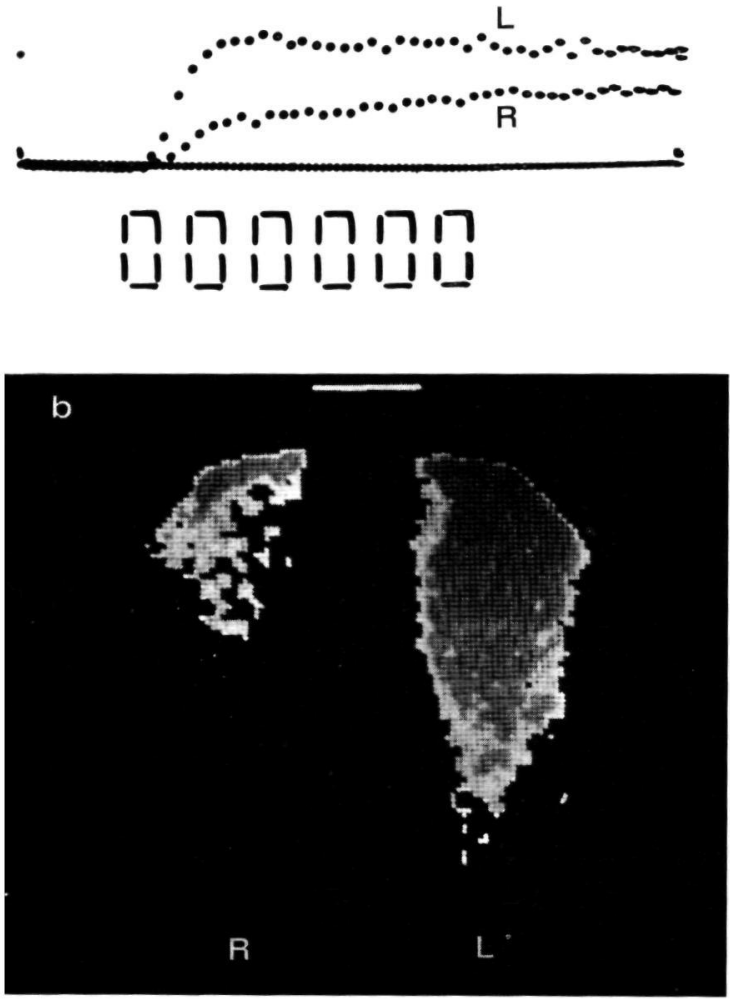

Fig. 16a: Activity-time curves of a patient with femoro-popliteal occlusion of both legs with pathologic run-off on the right side (lower curve).
Fig. 16b: Black-and-white reproduction of color-coded scintiphotos of the same patient, 40 seconds after the arrival of the activity in the legs.

the left and 0.7 on the right, which were interpreted as consistent with occlusion of the main artery on both sides with additional occlusion of the calf arteries on the right. Arteriography showed a tortuous lumbar aorta with bilateral occlusion of the distal femoro-popliteal segment with tiny collateral vessels providing a very faint indication of the anterior tibial artery on the left side but without run-off from the right (Fig. 17). Surgical exploration of the right leg demonstrated no back flow in the explored leg arteries, and only sympathectomy was performed. 


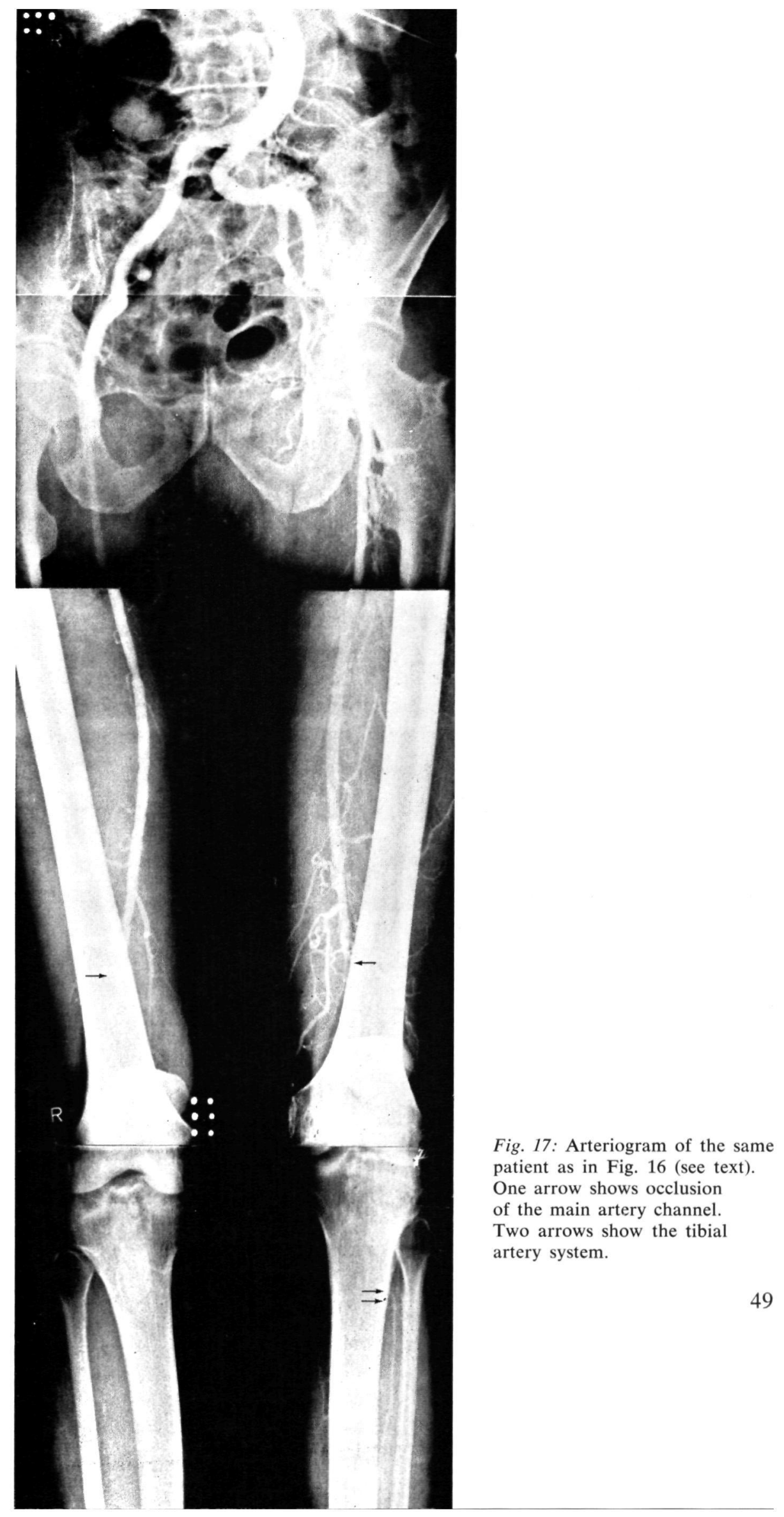


As demonstrated, curve patterns as well as activity distribution in regions of the leg correlate very well with the angiographic picture in indicating obstructive disease. The most striking feature in main channel obstruction is the absence of peak activity indicating blood flow through high-resistance collateral pathways, thus damping the normal contour of the curve.

By selecting three areas of interest, one covering the lower thigh, one the popliteal fossa, and one the upper part of the calf region, it is possible to indicate the location of a main channel obstruction. Many authors have reported the low occlusion rate of the profunda femoris artery (Lindbom, 1950; Margulis, 1957; Haimovici, 1960).

As a result, from the four theoretical possibilities mentioned in 4.4.2. only two are important. In patients with chronic arterial occlusion the resting blood flow may be normal, but the reserve flow capacity of the collateral arteries during maximal vasodilatation in the muscles after a period of ischemia may be insufficient. With iliac occlusion the entire limb is devoid of normal arterial inflow, thigh as well as calf, while in femoro-popliteal artery obstruction the patent profunda adequately provides the thigh muscles whereas there is a marked reduction of the calf blood flow.

Furthermore, as demonstrated above, serial imaging makes it possible to indicate vascular disease of the small muscular branches of the tibial artery system. The poor perfusion of the calf in advanced run-off vessel disease is evident.

\subsubsection{The pattern after vascular reconstruction}

In reconstructive surgery two main methods are utilized, namely the bypass graft and the thromboendarterectomy. Both are designed to preserve the existing collateral circulation and restore the arterial flow. The surgical approach can be divided into two levels: aorto-iliac and femoro-popliteal. The postoperative changes in the curve patterns and the activity distribution reflect the function of the graft. It is well known that after successful arterial reconstruction a normal hemodynamic flow pattern results, providing a normal activity distribution in the calf muscles and relief of the claudication pain.

Fig. 18a and $b$ : Black-and-white reproduction of color-coded scintiphotos and activity-lime curves of the calves of a patient with bilateral claudication complaints.

$c$ and $d$ : Scintiphotos and curve patterns after corrective surgery on the left side. Note normalization of activity distribution and curve pattern on the left.

$e$ and $f$ : Scintiphotos and curve patterns after corrective surgery on the right side as well. Normalization of the perfusion in both legs. 

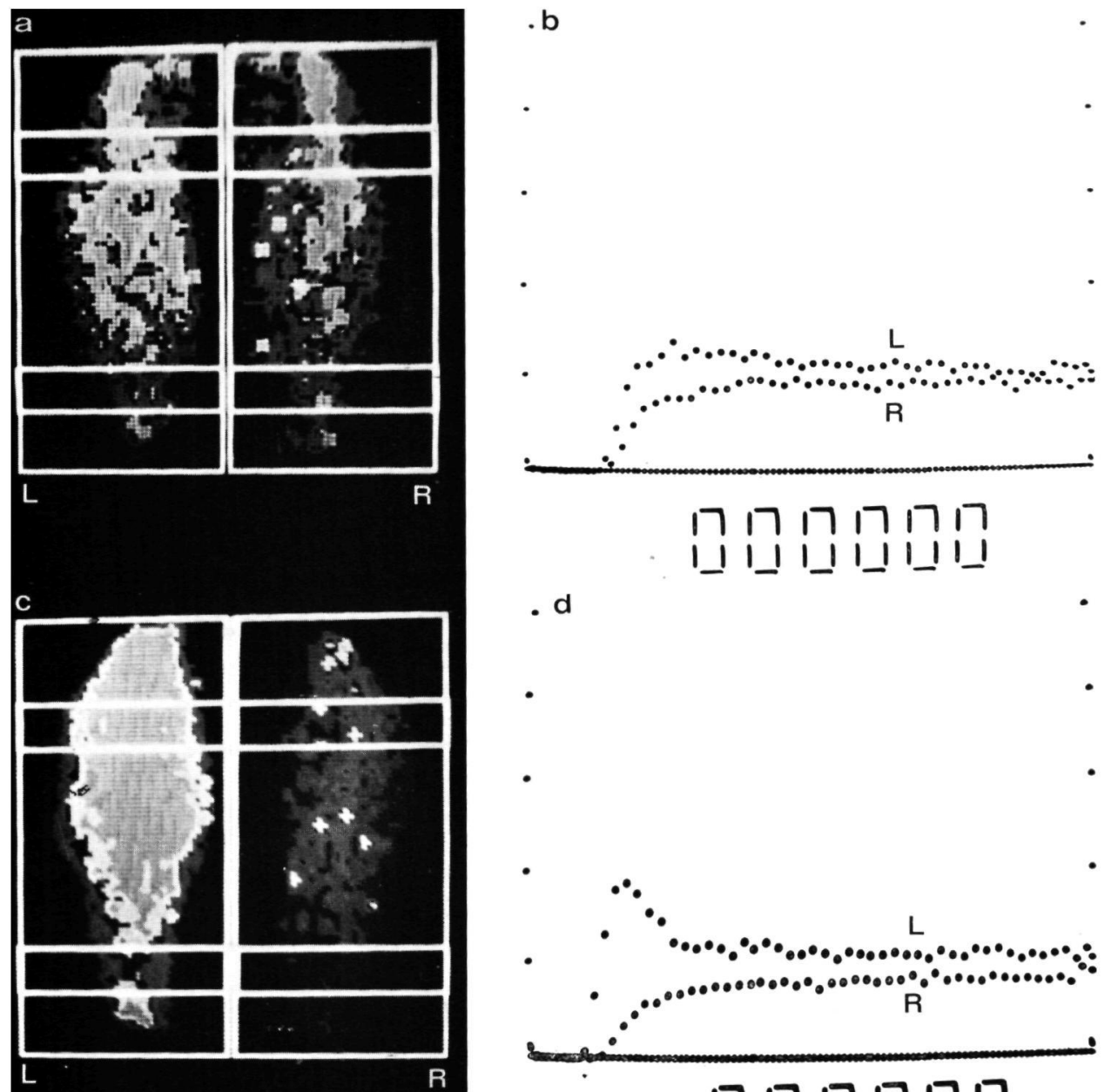

. d
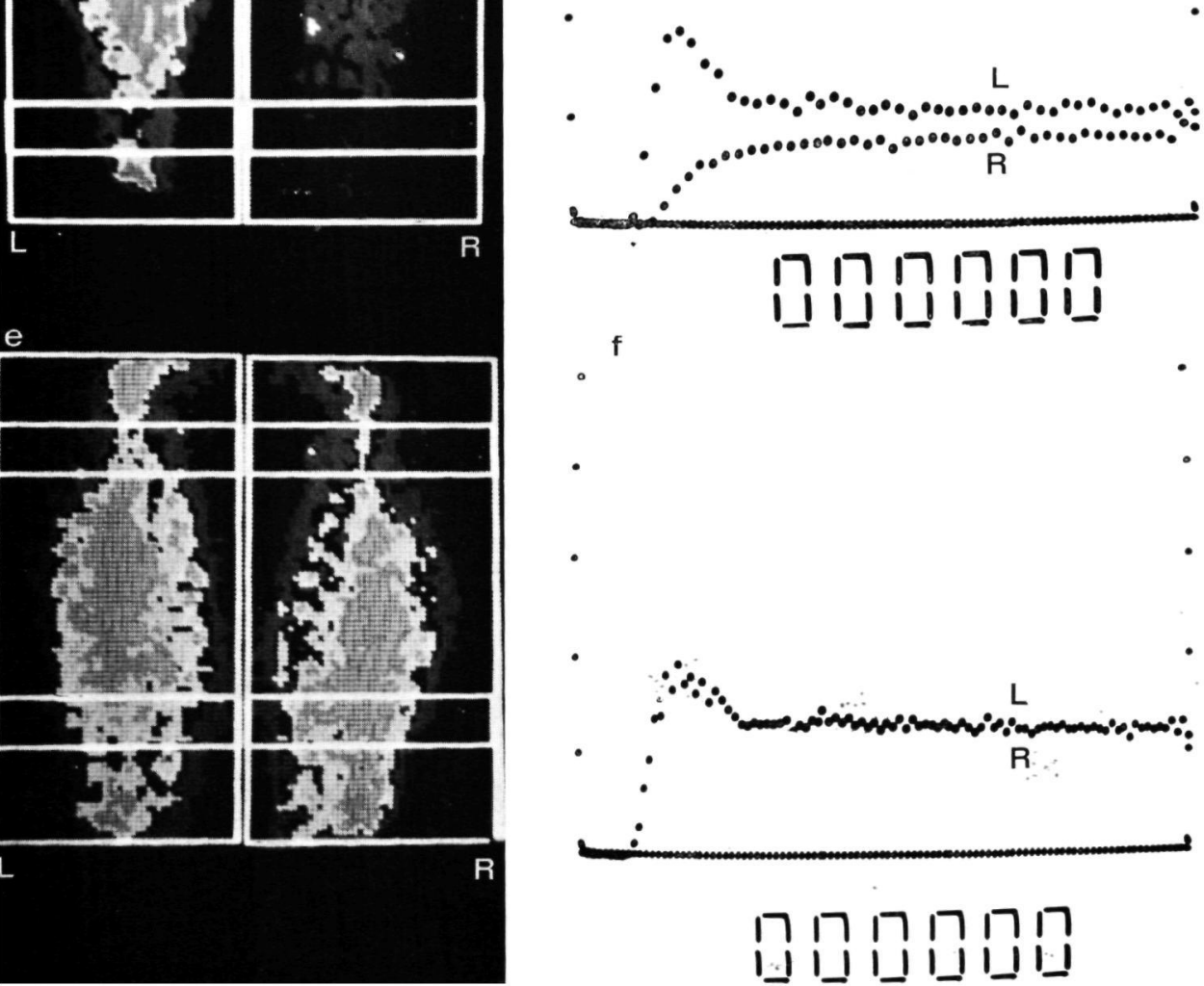


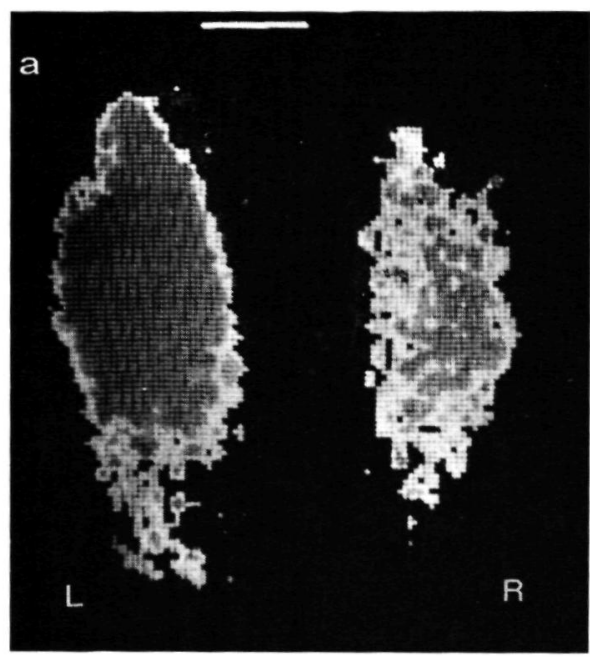

b

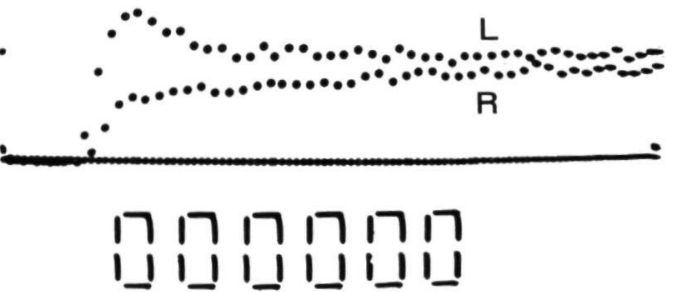

Fig. $19 a$ and $b$ : Black-and-white reproduction of color-coded scintiphotos and activity-time curves of a patient with occlusion of the femoro-popliteal segment down to the distal part of the popliteal artery on the right side.

This may be illustrated by the following case report. A 66-year-old man with more than two years claudication complaints in both legs after a walking distance of 150 meters was investigated. Before surgery the tracer study demonstrated pathologic curve patterns and activity distribution of both calves (Fig. 18). After hospitalization the arteriogram demonstrated occlusion of the superficial femoral artery in both legs. Following corrective surgery on the left side the tracer study was repeated, and a normal activity curve pattern on the left with good perfusion of the left calf indicated a well-functioning saphenous vein bypass graft. The right side demonstrated a pathologic perfusion as before with obviously a lower plateau. Three months later a femoro-popliteal vein bypass graft was placed in the right leg as well, and again two months after this second operation the tracer study was repeated. The result was a normal curve pattern as well as a symmetrical activity distribution of both calves, indicating a normal function of both grafts resulting in normal tissue perfusion after vascular surgery (Fig. 18). Clinically the patient had a complete relief of his claudication symptoms.

During the post-operative tracer study it is possible to visualize the transport of the activity in the distal anatomosis of the bypass graft and to identify the bypass activity from the collateral circulation. In cases where the proximal part of the popliteal artery was occluded or arteriosclerotic such that it was not suitable for anastomotic procedure, a distal anastomosis below the knee joint level to the distal part of the popliteal artery or the tibial arteries was performed. 
This is demonstrated by images obtained from a tracer study of a 73-yearold man with serious claudication pain in the whole right leg starting in the right calf without any clinical features of vascular insufficiency from the left leg. The preoperative tracer study showed a normal curve on the left with a P.I. value of 1.4 , but on the right the activity distribution was very poor with a very low curve pattern resulting in a P.I. value on only 0.7 (Fig. 19). The

a
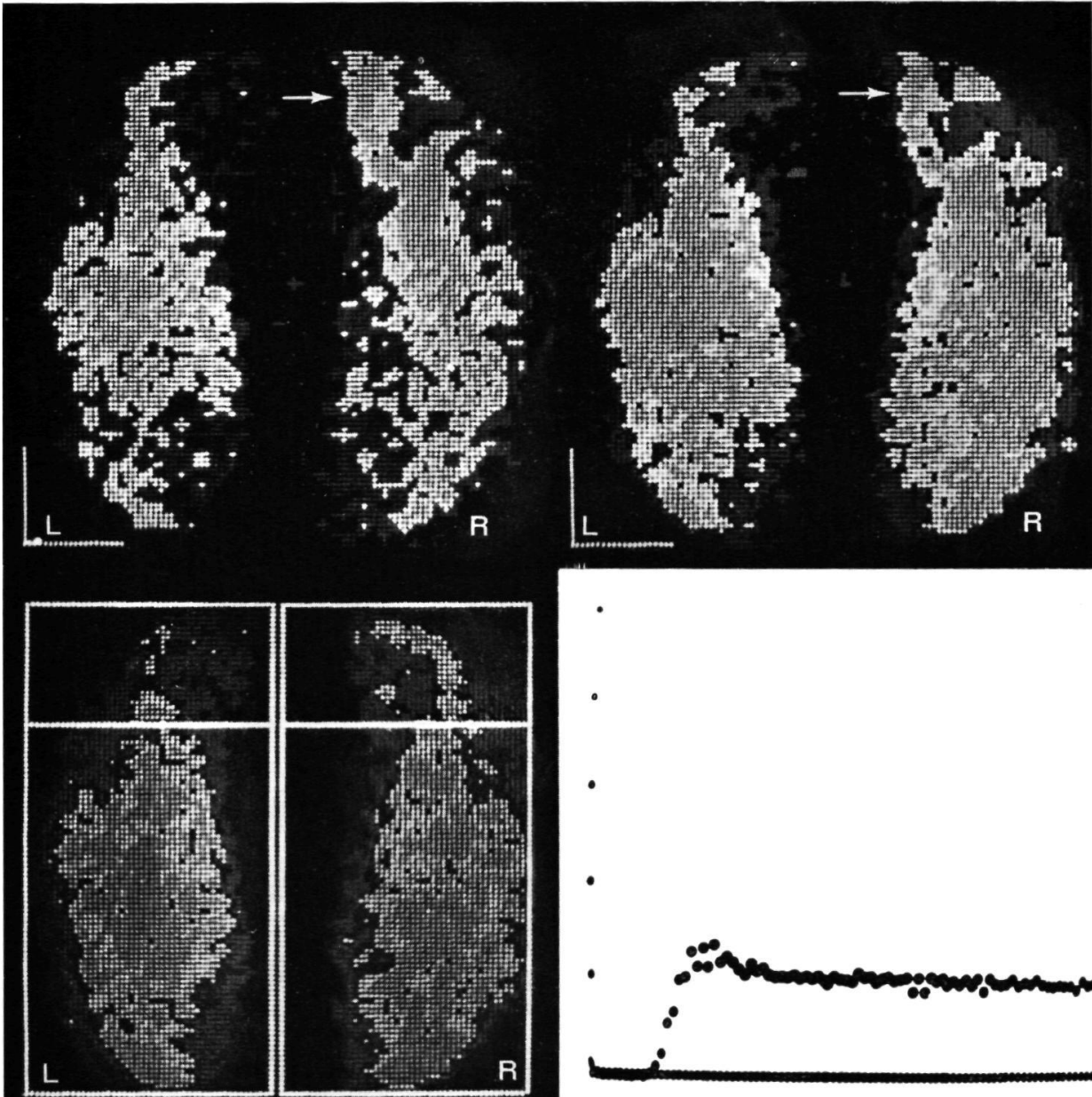

R

b

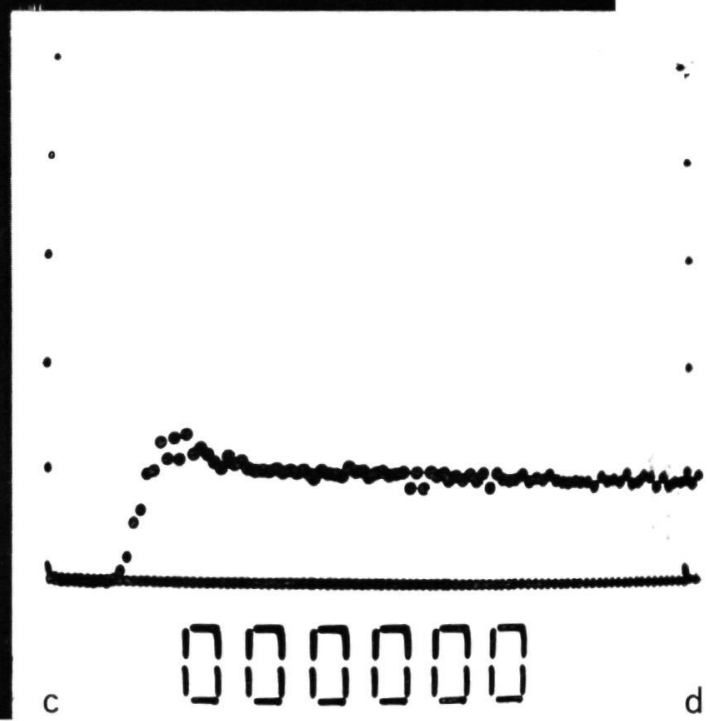

Fig. 20: Scintiphotos of the tracer study after corrective surgery on the right leg. Arrows indicate the transport of activity through the graft. 


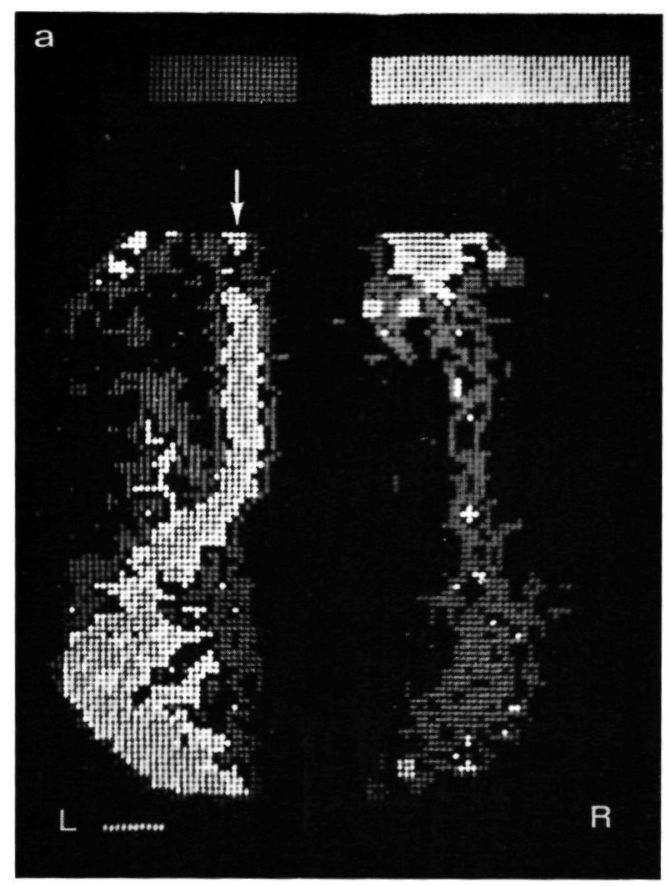

Fig. 21a: Scintiphoto of a patient after reconstructive surgery on both sides of the femoropopliteal segment. Note the activity in the graft on the left and its absence on the right. Fig. 21b: Activity curves: normal perfusion pattern on the left, pathologic pattern on the right.

angiogram demonstrated arteriosclerotic changes with stenosis in both iliac arteries as well as a total occlusion of the right femoro-popliteal segment down to the distal part of the popliteal artery. Because of good pulsations of both femoral arteries a long saphenous vein bypass graft was applied with distal anastomosis below the knee joint level, where the quality of the popliteal artery was fairly good. Five months after surgery a repeated tracer study demonstrated peak activity curves on both sides with a P.I. value of 1.2 on the right and 1.3 on the left (Fig. 20). Serial scintiphotos taken at 20 and 25 seconds after the intravenous injection clearly showed an activity distribution of the bypass image which demonstrated an excellent function in perfusing the calf muscles (Fig. 20). At the end of the study (Fig. 20c) the bypass was not visible anymore, indicating the dynamic progression of the arrival and distribution of the activity.

Fig. 22: Arteriographic study of the same patient as in Fig. 21. Arrow shows the substop in the graft. 


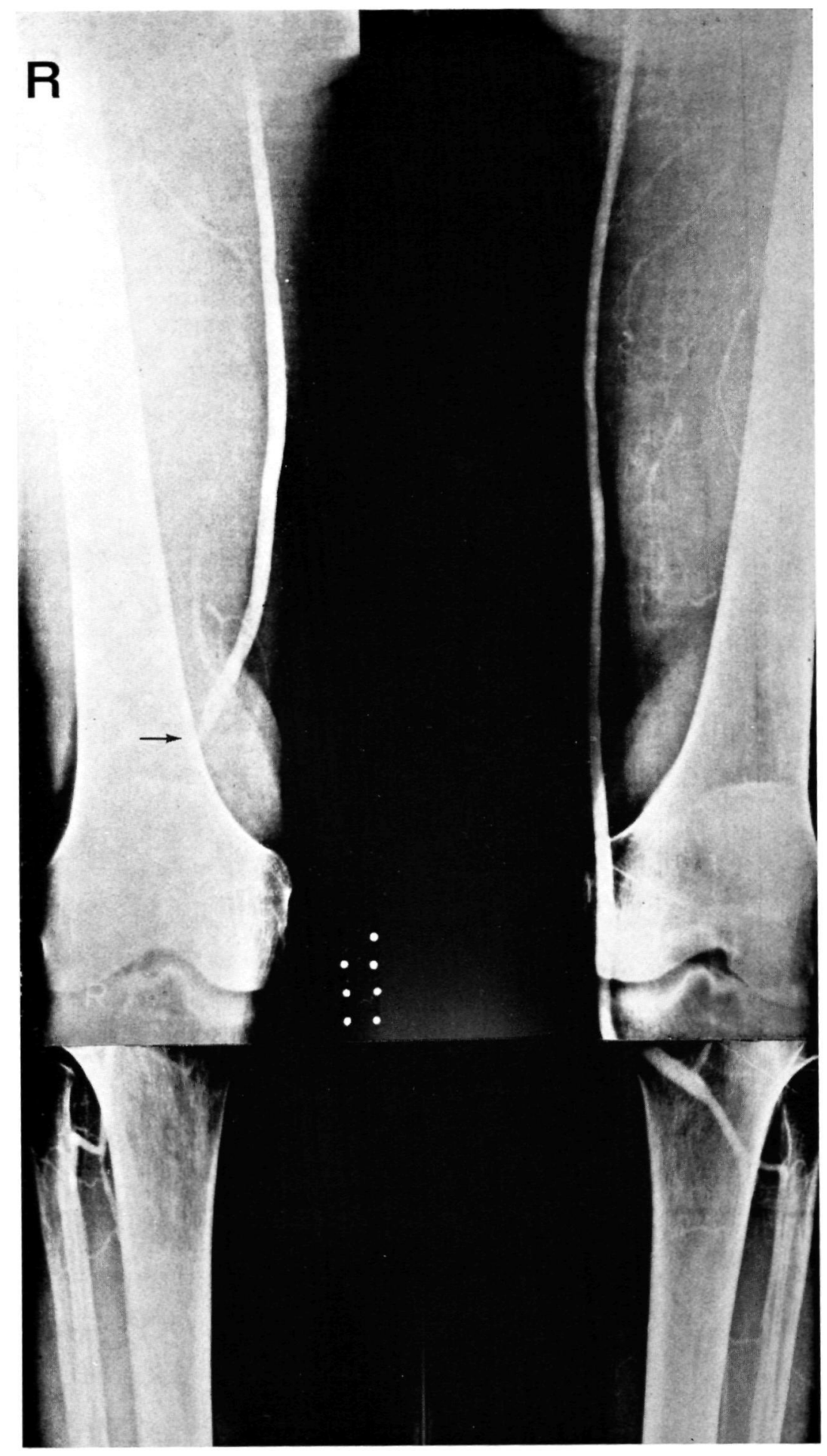



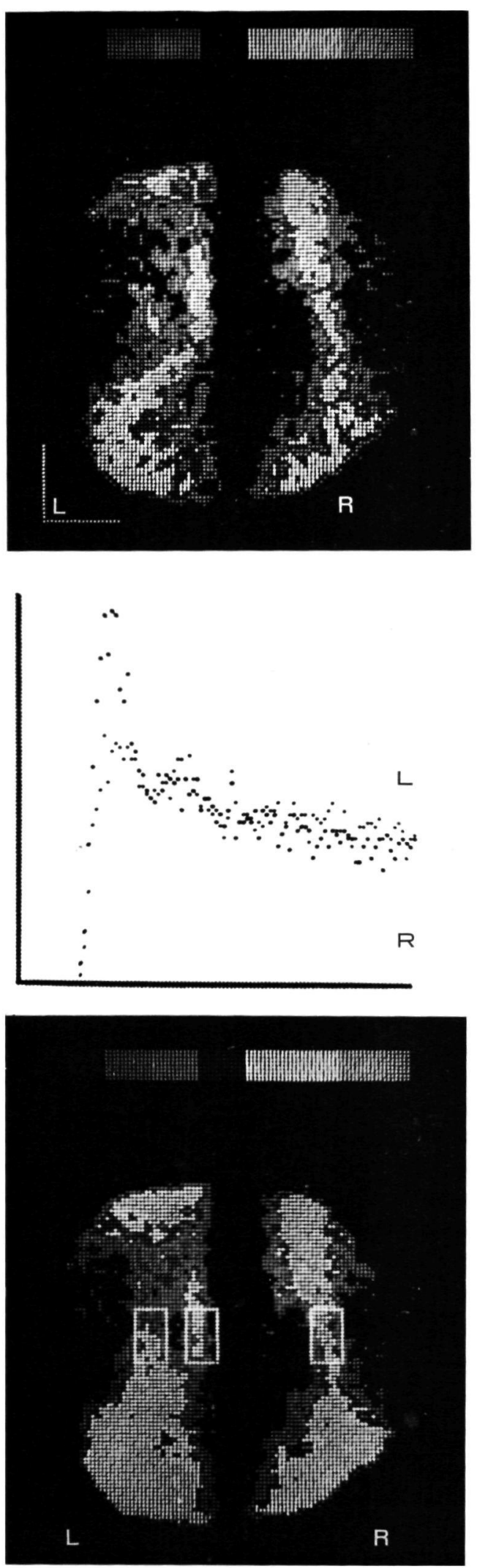

Fig. 23: Black-and-white reproduction of color-coded scintiphotos of the same patient after re-operation on the right side. Improvement in activity in the right calf, as seen on scintiphotos and activity curve below.

Lower scintiphoto shows areas of interest covering the graft and collateral region, on the left separately. 
A longer trajectory of venous bypass grafts could also be observed, and by means of small regions of interest covering the bypass course, time activity curves could be obtained.

This is demonstrated by the images from a study of a 56-year-old man with a bilateral occlusion of the femoro-popliteal segment, who underwent bilateral vascular reconstruction. The left vein bypass graft was anastomosed to a distal vessel below the knee. The right distal anastomosis was applied above the knee to the proximal part of the popliteal artery. After surgery his complaints on the left were completely relieved but persisted on the right. The tracer study demonstrated the transport of radioactivity through the well outlined bypass on the left in the popliteal region perfusing the calf tissues. On the right the perfusion of the thigh was excellent, however, the popliteal as well as the calf region were very poorly perfused. The scintiphotos correlate very well with the pathologic curve patterns obtained from the corresponding regions and normal peak activity curves from the patent regions (Fig. 21). This was confirmed by the angiogram demonstrating an open bypass on the left but a substop in the distal anastomosis on the right (Fig. 22). After reconstruction of the substop the repeated tracer study demonstrated the well functioning bypass on the left as well as improved perfusion of the right calf correlating with the obtained peak activity curves (Fig. 23). Small regions of interest were selected from the left leg covering the bypass excluding the collateral arteries. Fig. 24 shows curves of activity versus time in these regions. It is obvious that a high peak

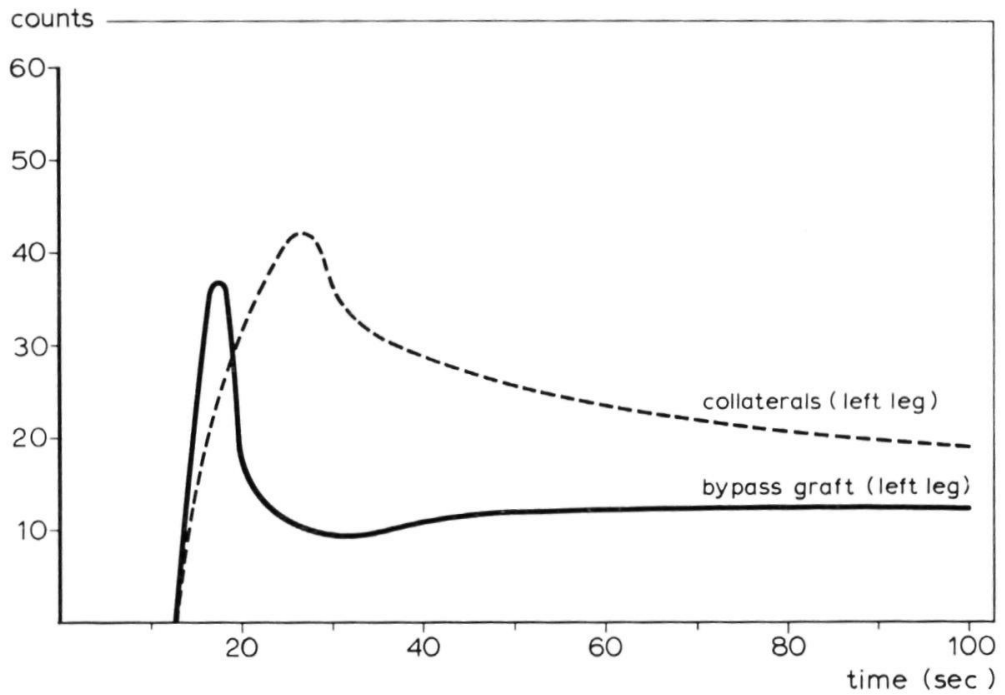

Fig. 24: Activity-time curves plotted from the data printed out, showing activity turn over in the bypass and the collateral region in the left leg. 
activity with a very low plateau is obtained from the bypass region, and on the other hand a damped peak with a slightly descending and relatively high plateau from the muscular region.

\subsubsection{Discussion}

In preoperative studies determination of leg perfusion in the calf is the main concern in occlusive disease both from surgical and clinical point of view. The influence of the extent of the vascular disease on the results after surgery will be reported in chapter $\mathrm{V}$. Activity-time curves, obtained from regions of interest selected to cover the bypass graft and the collateral circulation separately, reveal the different ways of functioning of both arterial pathways.

The collateral system acts as a rather high resistance consisting of many small arterial branches. In the midzone of the collateral circulation the activity bolus is transported distally, serving the vascular bed of the traversed muscles as well. The short peak activity of the curve obtained of the bypass region only demonstrates the transport function without perfusion of the tissues surrounding the graft itself.

When regions of decreased activity are visualized on the serial images, suggesting small areas of poor perfusion due to small vessel disease, this is indicative of a high peripheral resistance distal to an occlusion. Serious irregularities and arteriosclerotic changes of the run-off vessels appear to be an important factor in increasing peripheral resistance (Bliss, 1973).

As a result the flow rate through a bypass might be low due to lack of pressure gradient with a high early failure rate in this group of patients. In the patient demonstrated in Fig. 13 the graft was occluded two months after surgical reconstruction and repeated surgery was required. The value of a follow-up tracer study in guiding the surgeon in deciding on subsequent management is also illustrated.

\subsubsection{Pattern anomalies due to factors other than arteriosclerosis obliterans}

\subsubsection{Injection in cephalic vein}

Commonly the bolus is injected in a medially located antecubital vein. However, when this vein group is not suitable for intravenous injection, the bolus is delivered into the cephalic vein group. Utilizing an injection technique propelling the bolus with a saline flush, the obtained activity curve pattern in one patient (see 2.5.1.) demonstrated division of the bolus into two discernible components as described by Watson et al. (1973).

The patient was a 41-year-old man with claudication complaints, but no resting pain after a walking distance of 150 meters. The tracer study prior to the 


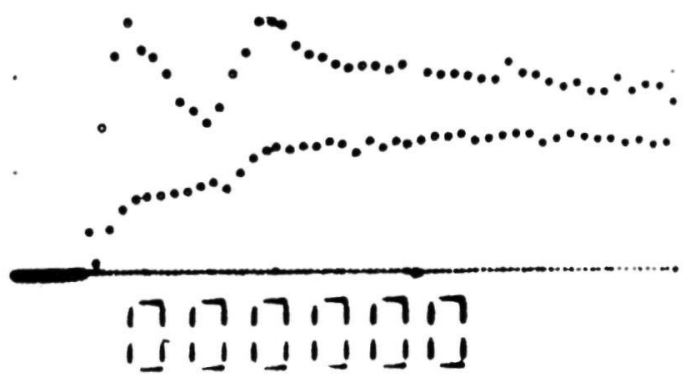

Fig. 25: Influence of injection technique on the activity-time curve patterns.

arteriogram demonstrated a poor activity distribution, which clinically correlated with his complaints, as well as an obviously pathologic curve pattern (Fig. 25). The fast component of the curve demonstrated a "steplike" rise in activity. The curve pattern obtained from the other leg showed a double peak with a dip between both peaks. The pattern was reported as compatible with a patent vascular system in that leg. This was confirmed by the angiogram demonstrating a patent vasculature on one side and an occlusion of the artery of the opposite leg.

\subsubsection{Discussion}

Even with a total division of the bolus activity into two components, the curve patterns obtained demonstrate the characteristic difference between pathologic and normal. Furthermore the influence of bolus variation is more pronounced in legs with normal vasculature. In pathologic circulation high-resistance collateral pathways result in a stepwise curve due to the delay of the second part of the bolus. This delay of the second component of the bolus is more or less simultaneous in both legs and therefore does not interfere with the color-coded images representing the activity distribution at any given moment in both legs.

The incidence of the division of the bolus into two components in our material is low. In normals some curves demonstrated a second low peak directly following the slope of the main peak segment. These small peaks might be due to delayed arrival of activity initially trapped in cephalic veins during the bolus injection. They have no consequences for the interpretation of the obtained curves. 
As mentioned above (2.9) the pressure in the cuff is released before the injection of the radioactivity. However, in one case the activity was already delivered and the release of the cuff pressure started nearly at the same time as the arrival of the injected bolus in the legs. Both cuffs used in this way acted as an extra resistance on the passage of the activity bolus. As a result both curves demonstrated pathologic patterns without true peak activity (Fig. 26a). The curve pattern obtained from the activity data on the left showed a lower course than the curve from the right.

Because of this technical mistake the procedure was repeated after one week. The curve pattern of the left leg demonstrated again an obviously pathologic curve, but on the right a normal peak activity was visualized (Fig. 26b). The patient was a 67-year-old man with claudication pain in his left calf as well as foot after a walking distance of 100 meters but without resting pain or ulcerations. The angiogram demonstrated occlusion of the distal femoro-popliteal segment with visualization of the posterior tibial artery only. Surgical exploration demonstrated a small caliber of this vessel. A bypass procedure would have had a very poor prognosis even if it had been possible. Hence the decision was made to perform sympathectomy.

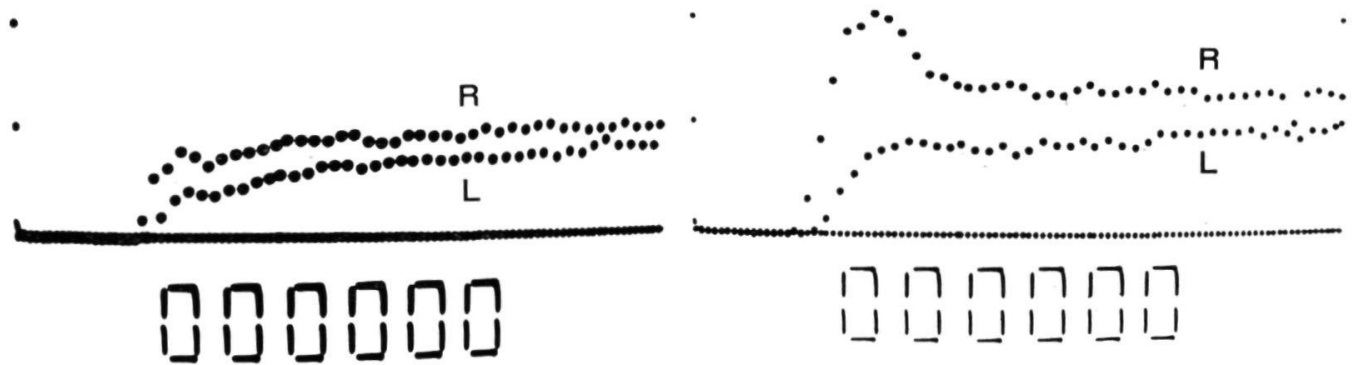

Fig. 26a: Distorted curve patterns due to faulty release of cuff pressure.

Fig. 26b: Test repeat, showing normal pattern on the right and pathologic pattern on the left. 


\subsubsection{Discussion}

The extravascular tissue pressure due to the compression of both cuffs during the arrival of the activity is an additional resistance to the passage of the bolus, damping both curve contours. However, it is obvious that the outcome of this effect is much more marked in the leg with patent vasculature, demonstrating as a result an absence of the peak. On the other hand in the left leg an arterial occlusion, already present with a poor run-off and acting as an actual resistance to the bolus transport, resulted in a relatively small effect of the additional cuff resistance. The necessity of free passage of the activity bolus through the vasculature is stressed, otherwise false positive results would be obtained. 


\section{STATISTICAL ANALYSIS OF THE RESULTS}

\subsection{Introduction}

In the previous chapter the patterns of normal and pathologic tracer studies were described. In this chapter the results of the tracer study in normal subjects and in patients are statistically analyzed.

In group $A$ of 28 normal subjects the tracer parameters are evaluated according to side (right versus left), age and sex. In group B of 104 patients the same evaluation was performed as well as comparison of the parameter values before and after subsequent management.

The severity of patient complaints, i.e. the clinical stage of peripheral vascular disease as defined below (5.6), was correlated with the angiographic diagnosis which in turn was compared to the tracer parameters.

The relation between the parameters and the angiographic diagnosis was investigated in the same patient and in all legs. The total number of legs (208) belonging to the total patient material (104) was subdivided into 5 subgroups according to the angiographic diagnosis as defined in Table I.

Evaluation of the parameters in the five leg types of the subgroups was performed under the theoretical assumption that every subgroup was representative for a hypothetical population of the same leg type.

The tracer parameter values in each of the five subgroups before and after subsequent treatments were also analyzed.

\section{GROUP A: NORMAL SUBJECTS}

\subsection{Differences in parameter values in right and left leg of the same subject}

The $t_{t}$ of the right and left leg in 27 subjects was equal. Only in one subject the $t_{a}$ obtained from the right leg was one second longer compared to the left (left $\mathrm{t}_{\mathrm{a}}=\mathbf{8} \mathrm{sec}$ and right $\mathrm{t}_{\mathrm{t}}=9 \mathrm{sec}$ ).

Some variability was demonstrated in the $t_{m, x}$ and the perfusion index. The $t_{\max }$ in 20 subjects was equal for the right and left leg. In three subjects the $t_{\text {tuax }}$ for the right leg was $1 \mathrm{sec}$ longer than for the opposite side. In 5 subjects 
the $t_{\text {max }}$ was shorter for the right leg, in 4 subjects by 1 sec and in 1 subject by 2 seconds.

The differences related to the P.I. values are summarized in Table II. There are obvious differences in the obtained P.I. values of the left and right leg, but systematic differences are not observed.

The Plateau Ratio for both legs was equal.

Table II. Difference of the perfusion index values between right and left leg (normal subjects group).

$$
\text { perfusion index: right - left }
$$

$$
\begin{array}{lllllll}
-0.3-0.2 & -0.1 & 0.0 & 0.1 & 0.2 & 0.3 & 0.4
\end{array}
$$

$\begin{array}{lllllllll}\text { frequency } & 3 & 0 & 7 & 9 & 5 & 3 & 0 & 1\end{array}$

\subsection{Differences in parameter values obtained in men and women}

The results are summarized in Table III. Utilizing Wilcoxon's test it is not demonstrated that, when the men and women are considered as samples, there is a difference in age between men and women. However there is an indication that the perfusion index for men is higher than for women on the average.

Table III. Comparison of the parameter values in males and females.

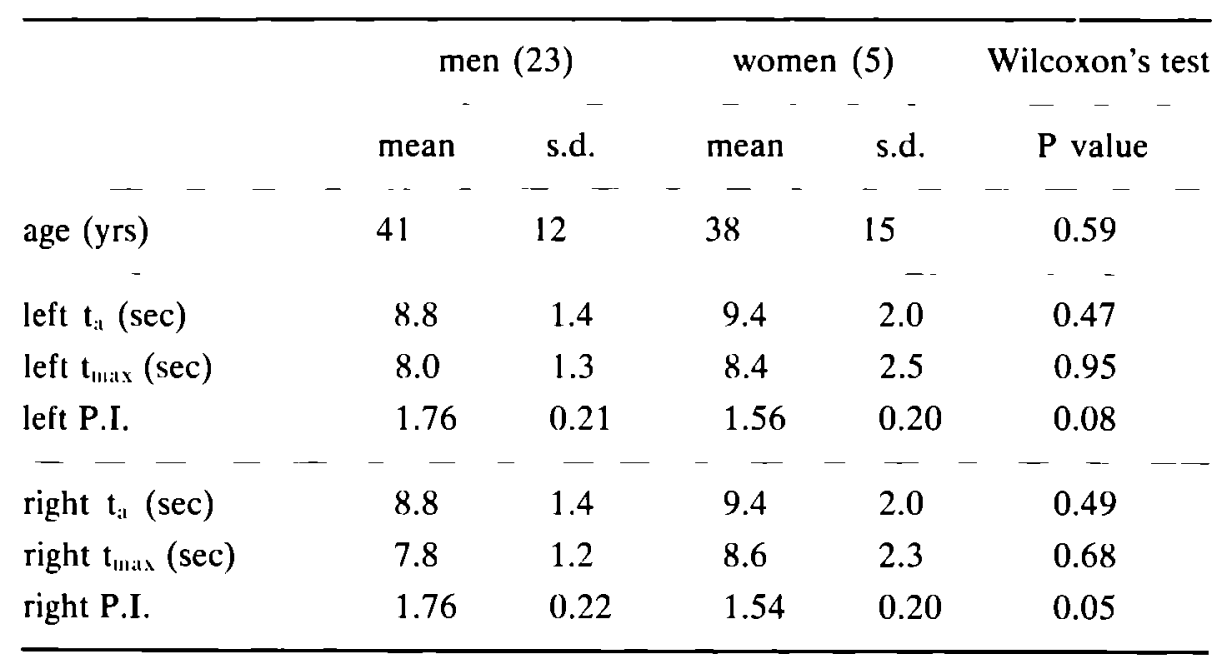


5.4. Correlations of the measured parameters with the age of men and women separately

The Spearman correlations (Table IV) indicated that there is a longer $t_{a}$ with increasing age in men. There seems to be such a positive correlation between $t_{111 x}$ and age in men as well, though statistically not significant. Less clear is the correlation between the perfusion index and the age.

Summing up the results, it is not obvious that the indication for a difference between men and women with respect to the perfusion index might be caused by a difference in age. We must consider, however, that the number of women in this sample is relatively small.

Table $I V$. Spearman correlation of age to parameters $\mathrm{t}_{11}, \mathrm{t}_{1 \mathrm{x}}$ and P.I.

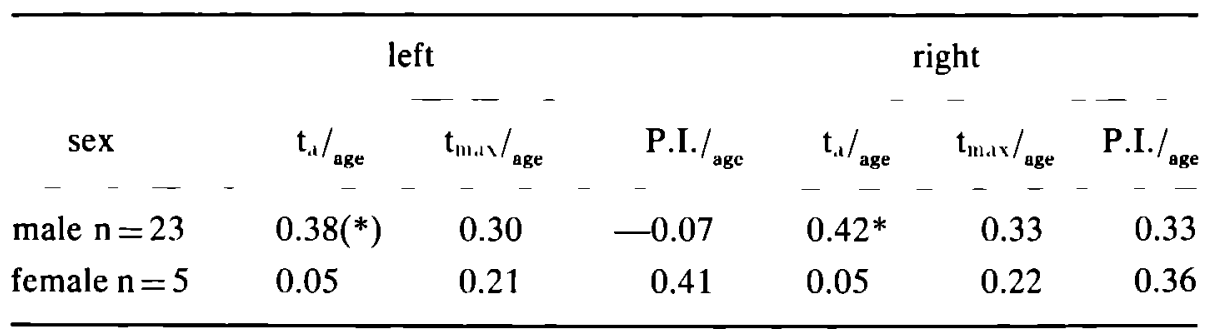

Meaning of symbols: blank $=$ not significant $\mathrm{p}>0.10$

$$
\begin{aligned}
\left({ }^{5}\right) & =\text { indication } 0.05<p \leqslant 0.10 \\
* & =\text { significant } p \leqslant 0.05
\end{aligned}
$$

\subsection{Discussion}

An analysis of the perfusion patterns as well as of the activity turn over in normal subjects without peripheral arterial disease is necessary as a control study for the patient material. In the "normal" group absence of vascular disease is assumed. We found it unjustifiable to test this assumption objectively by performing angiography.

The above results indicate that there might be a difference between the P.I. value for the right and left leg in the same subject. These differences could be due to minor biological variations in the perfusion pattern of each leg, but variations in the state of reactive hyperemia or technical artifacts cannot be excluded. Systematic differences, on the other hand, between the right and left leg were not observed. There is an indication that the perfusion index for men is higher than for women on the average. However one has to be cautious in generalizing this finding in view of the limitation in the selection of the samples of men and women. To investigate age as a factor for this difference the Spearman correlations between the age and the obtained parameters for men 
and women were calculated separately. There is an indication for a positive correlation between $t_{i}$ and age in men, which means that there is a prolongation of the arrival time with increasing age. Not statistically significant but suggestive is the presence of a positive correlation for $t_{\text {max }}$ and age in men. The correlation between the Perfusion Index values and the age is less clear. A priori a ncgative correlation was expected.

From the data of this study it is not clear whether the indication for a difference between men and women might be explained by differences in age. The indication that the mean P.I. value score in women is somewhat lower than that in men might be related to biological differences in the muscle and fatty tissue systems of men and women.

\section{GROUP B: PATIENTS}

\subsection{Clinical classification correlated to angiographic diagnosis}

Peripheral vascular disease is clinically classified according to Fontaine et al. (1954) into 4 stages. In stage I the vascular disease is symptomless. In stage II claudication complaints are present whereas in stage III the claudication is complicated by resting pain. In stage IV there are serious trophic disturbances of the legs with ulcerations or gangrene. The relation between clinical status and angiographic diagnosis (Table I) was investigated. The results are summarized in Table V. From these data it is clear that absence of complaints is not always

Table $V$. Clinical classification correlated to the angiographic diagnosis (208 legs).

$\begin{array}{lccccc}\text { patent } & \text { stenosis } & \begin{array}{c}\text { single } \\ \text { occlusion }\end{array} & \begin{array}{c}\text { multiseg- } \\ \text { mental } \\ \text { occlusions }\end{array} & \begin{array}{c}\text { poor } \\ \text { run-off }\end{array} & \begin{array}{c}\text { number } \\ \text { total }\end{array}\end{array}$

\begin{tabular}{|c|c|c|c|c|c|c|c|c|c|c|c|}
\hline 1. asymptomatic & 42 & 78 & 15 & 50 & 4 & 8 & 2 & 5 & 0 & 0 & 63 \\
\hline 2. claudication & 12 & 22 & 15 & 50 & 44 & 92 & 29 & 76 & 23 & 61 & 123 \\
\hline $\begin{array}{l}\text { 3. same as } \\
2+\text { restpain }\end{array}$ & 0 & 0 & 0 & 0 & 0 & 0 & 6 & 16 & 14 & 37 & 20 \\
\hline $\begin{array}{l}\text { 4. same as } 3 \text { with } \\
\text { ulcerations or } \\
\text { gangrene }\end{array}$ & 0 & 0 & 0 & 0 & 0 & 0 & 1 & 3 & 1 & 2 & 2 \\
\hline total number & 54 & 100 & 30 & 100 & 48 & 100 & 38 & 100 & 38 & 100 & 208 \\
\hline
\end{tabular}


correlated with a patent angiogram. This is illustrated below in case report K.v.W. (5.9.1.).

In our material 63 legs were clinically not suspect for vascular disease, but in only $42(68 \%)$ the legs were angiographically patent. On the other hand in 6 patients with unilateral complaints suspected for vascular disease, the tracer study demonstrated normal symmetrical peak activity curves, subsequently confirmed by patent angiographic vasculature, as illustrated below in case report A.v.d.K. (5.9.2.).

5.7. Comparison of angiographic diagnosis in the same patient related to the tracer parameters

The "leg-type" classification based on the angiographic diagnosis (Table I) was applied to the total material of 104 patients, resulting in their grouping into 15 different "patient types".

Type one: patients with two patent legs.

Type two: patients with one patent leg and the other stenotic.

Type three: patients with one patent leg and the other with an occlusion of a single vascular segment.

Type four: patients with one patent leg and the other with multisegmental occlusions, and so on to the severest type fifteen consisting of patients with a poor run-off of both legs (Table VIa).

Table VIa. Division of subjects into 15 different types

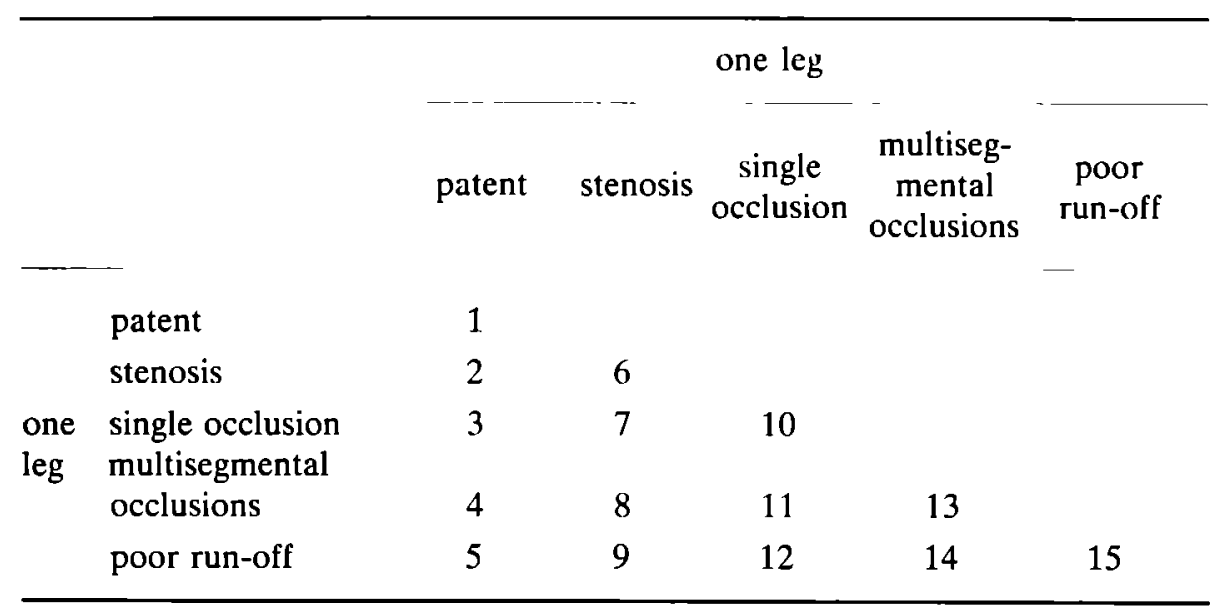

The table is diagonally symmetrical. 
Table VIb. Distribution of 104 subjects according to arteriographic diagnosis of the legs $\square$.

\begin{tabular}{|c|c|c|c|c|c|c|}
\hline & & & & one leg & & \\
\hline & & & $-\quad-\quad-$ & $-\quad-\quad-$ & $-\ldots-$ & $-\quad-\quad-$ \\
\hline & & patent & stenosis & $\begin{array}{c}\text { single } \\
\text { occlusion }\end{array}$ & $\begin{array}{c}\text { multiseg- } \\
\text { mental } \\
\text { occlusions }\end{array}$ & $\begin{array}{l}\text { poor } \\
\text { run-off }\end{array}$ \\
\hline \multirow[t]{3}{*}{-} & - & - & - & & $-\quad-\quad-\quad-$ & \\
\hline & patent & 8 & & & & \\
\hline & stenosis & 5 & 3 & & & \\
\hline \multirow{3}{*}{$\begin{array}{l}\text { one } \\
\text { leg }\end{array}$} & single occlusion & 22 & 8 & 4 & & \\
\hline & occlusions & 4 & 7 & 9 & 7 & \\
\hline & poor run-off & 7 & 4 & 1 & 4 & 11 \\
\hline
\end{tabular}

The table is diagonally symmetrical.

The distribution of patients in each type is summarized in Table VIb.

The angiographic diagnosis in both legs is equal in 33, and different in 71 out of 104 patients.

Subsequently for every parameter $\left(t_{1}, t_{m .1}\right.$, P.I. and P.R.) the comparable values of the parameters of the opposite leg were related to the angiographic diagnosis (Table VII, VIII, IX, X). Table XI shows a survey of the behavior of the parameters as related to the differences of the diagnosis within the same subject.

From the data obtained, the following conclusions may be drawn:

- The angiographically worse leg generally has higher values of $t_{d}$ and $t_{m \ldots}$. However, in 11 out of 71 patients equal values for $t_{d}$ and $t_{m a x}$ were obtained for both legs in spite of different angiographic diagnoses. Furthermore an inverse relation was observed in another 11 patients out of 71 , in whom the obtained $t_{m \ldots,}$ of the worse leg was shorter than the $t_{\mathrm{m}, \mathrm{s}}$ obtained from the better leg.

- In all 71 patients with unequal diagnosis of both legs the perfusion index of the better leg has a higher value than the corresponding value of the worse leg. From the data it is clear that the perfusion index is the best parameter to differentiate between worse and better legs within one subject. The P.I. is equal only when both legs are in the same condition. On the other hand, when the arteriographic diagnosis is the same for both legs, the obtained values are not always equal. 
Table VII. Comparison of the parameter values $t_{1}$ of the legs within one patient related to the arteriographic diagnosis of the legs (15 types) $\square$.

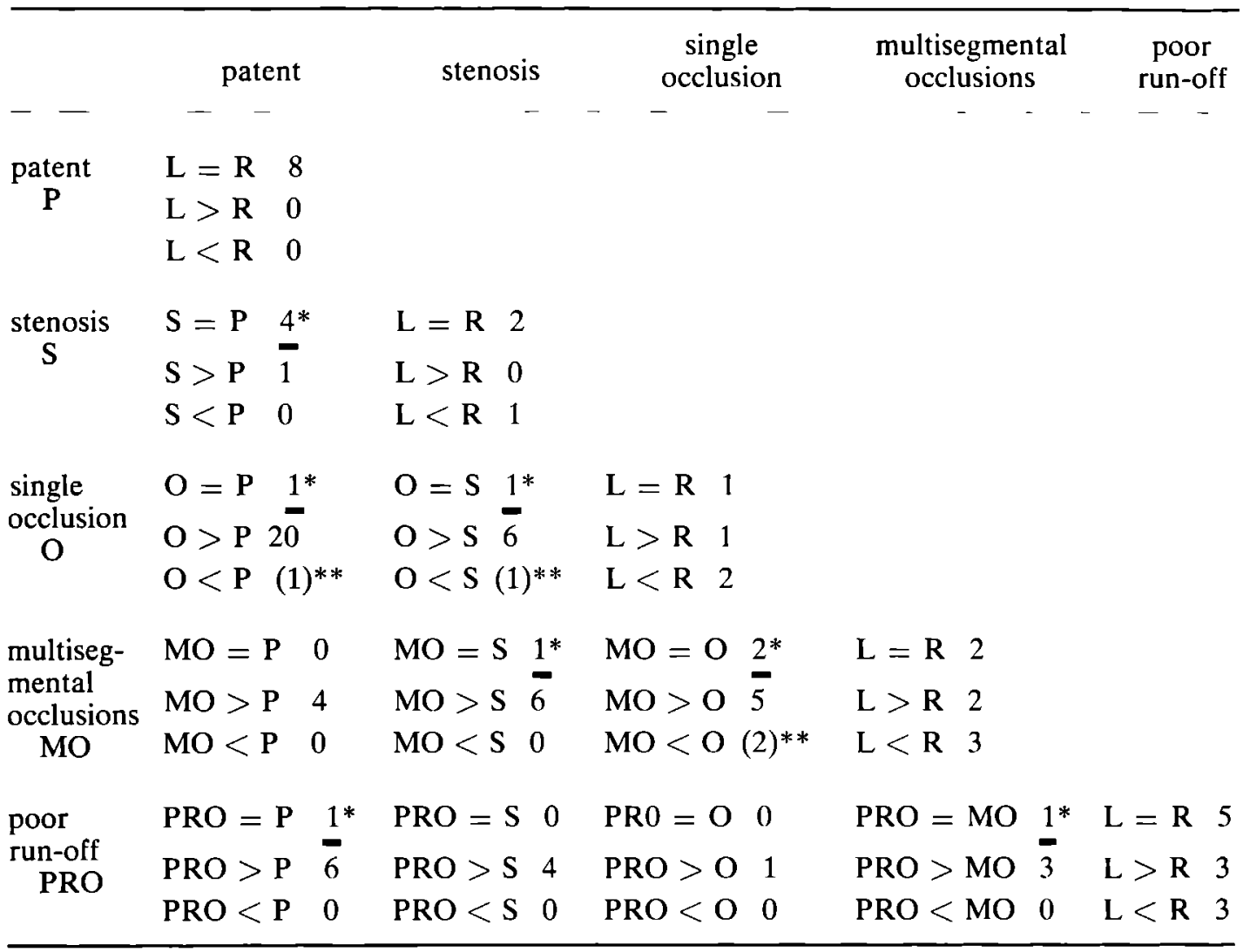

* The underlined numbers indicate equal values despite different angiographic diagnosis

** The numbers between brackets indicate inverse relation of the worse leg

$\mathbf{L}=$ Left $\quad \mathbf{R}=$ Right

The table is diagonally symmetrical.

- The plateau ratio for both legs was often equal, even when each leg demonstrated a different arteriographic diagnosis. However, a lower plateau never corresponded to the leg with a better arteriographic diagnosis.

- The opposite extremity acts as a control for the extremity under study; this is illustrated below in case report J.S. (5.9.3) (see also Fig. 6a and b). 
Table VIII. Comparison of parameter values $t_{111,}$ of the legs within one patient related to the arteriographic diagnosis of the legs (15 types) $\square$.

\begin{tabular}{|c|c|c|c|c|c|}
\hline & patent & stenosis & $\begin{array}{c}\text { single } \\
\text { occlusion }\end{array}$ & $\begin{array}{c}\text { multisegmental } \\
\text { occlusions }\end{array}$ & $\begin{array}{l}\text { poor } \\
\text { run-off }\end{array}$ \\
\hline- & $-\quad-$ & ----- & $-\quad-\quad-$ & ------- & $-\ldots$ \\
\hline $\begin{array}{l}\text { patent } \\
\mathbf{P}\end{array}$ & $\begin{array}{ll}\mathrm{L}=\mathrm{R} & 2 \\
\mathrm{~L}>\mathrm{R} & 1 \\
\mathrm{~L}<\mathrm{R} & 5\end{array}$ & & & & \\
\hline $\begin{array}{l}\text { stenosis } \\
\mathrm{S}\end{array}$ & $\begin{array}{l}\mathrm{S}=\mathrm{P} \quad 0 \\
\mathrm{~S}>\mathrm{P} \quad 3 \\
\mathrm{~S}<\mathrm{P} \quad(2)^{* *}\end{array}$ & $\begin{array}{l}\mathrm{L}=\mathrm{R} \\
\mathrm{L}>\mathrm{R} \\
\mathrm{L}<\mathrm{R}\end{array}$ & & & \\
\hline $\begin{array}{l}\text { single } \\
\text { occlusion } \\
\quad \mathrm{O}\end{array}$ & $\begin{array}{l}\mathrm{O}=\mathrm{P} \mathbf{3}^{*} \\
\mathrm{O}>\mathrm{P} 18 \\
\mathrm{O}<\mathrm{P} \quad(1)^{* *}\end{array}$ & $\begin{array}{l}\mathrm{O}=\mathrm{S} \mathbf{2}^{*} \\
\mathrm{O}>\mathrm{S} \\
\mathrm{O}<\mathrm{S}(1)^{* *}\end{array}$ & $\begin{array}{ll}L=R & 1 \\
L>R & 2 \\
L<R & 1\end{array}$ & & \\
\hline $\begin{array}{l}\text { multiseg- } \\
\text { mental } \\
\text { occlusions } \\
\quad \text { MO }\end{array}$ & $\begin{array}{l}\mathrm{MO}=\mathrm{P} \quad 0 \\
\mathrm{MO}>\mathrm{P} \quad 3 \\
\mathrm{MO}<\mathrm{P} \quad(1)^{* *}\end{array}$ & $\begin{array}{l}\mathrm{MO}=\mathrm{S} \quad 1^{*} \\
\mathrm{MO}>\mathrm{S} \quad 4 \\
\mathrm{MO}<\mathrm{S}(2)^{* *}\end{array}$ & $\begin{array}{l}\mathrm{MO}=\mathrm{O} 4^{*} \\
\mathrm{MO}>\mathrm{O} \\
\mathrm{MO}<\mathrm{O}(1)^{* *}\end{array}$ & $\begin{array}{ll}\mathrm{L}=\mathrm{R} & 1 \\
\mathrm{~L}>\mathrm{R} & 4 \\
\mathrm{~L}<\mathrm{R} & 2\end{array}$ & \\
\hline $\begin{array}{l}\text { poor } \\
\text { run-off } \\
\text { PRO }\end{array}$ & $\begin{array}{l}\mathrm{PRO}=\mathrm{P} \\
\mathrm{PRO}>\mathrm{P} \\
\mathrm{PRO}<\mathrm{P}\end{array}$ & $\begin{array}{l}\mathrm{PRO}=\mathrm{S} 0 \\
\mathrm{PRO}>\mathrm{S} 3 \\
\mathrm{PRO}<\mathrm{S}(1)^{*}\end{array}$ & $\begin{array}{l}\mathrm{PRO}=\mathrm{O} \quad 0 \\
\mathrm{PRO}>\mathrm{O} \\
\mathrm{PRO}<\mathrm{O}\end{array}$ & $\begin{array}{l}\mathrm{PRO}=\mathrm{MO} 0 \\
\mathrm{PRO}>\mathrm{MO} 2 \\
\mathrm{PRO}<\mathrm{MO}(2)^{* *}\end{array}$ & $\begin{array}{ll}\mathrm{L}=\mathrm{R} & 3 \\
\mathrm{~L}>\mathrm{R} & 5 \\
\mathrm{~L}<\mathrm{R} & 3\end{array}$ \\
\hline
\end{tabular}

The underlined numbers indicate equal values despite different angıgraphıc diagnosis

$\because$ The numbers between brackets indicate inverse relation of the worse leg.

$\mathrm{L}=$ Left $\quad \mathbf{R}=$ Right

$[$ The table is diagonally symmetrical. 
Table IX. Comparison of the P.I. values of the legs within one patient related to the arteriographic diagnosis of the legs (15 types) $\square$.

\begin{tabular}{|c|c|c|c|c|c|c|c|c|c|}
\hline & patent & & stenosis & & $\begin{array}{r}\text { single } \\
\text { occlusi }\end{array}$ & & $\begin{array}{r}\text { multisegmen } \\
\text { occlusions }\end{array}$ & & $\begin{array}{l}\text { poor } \\
\text { run-off }\end{array}$ \\
\hline--- & $-\cdots--$ & -- & $-\ldots-$ & - & $-\quad-\quad--$ & - & $-\quad-\quad-$ & & $\ldots-1$ \\
\hline \multirow{3}{*}{$\begin{array}{l}\text { patent } \\
\quad P\end{array}$} & $\mathrm{~L}=\mathrm{R}$ & & & & & & & & \\
\hline & $\mathrm{L}>\mathrm{R}$ & & & & & & & & \\
\hline & $\mathbf{L}<\mathrm{R}$ & & & & & & & & \\
\hline \multirow{3}{*}{$\begin{array}{l}\text { stenosis } \\
\mathrm{S}\end{array}$} & $\mathbf{S}=\mathbf{P}$ & & $L=R \quad 1$ & & & & & & \\
\hline & $\mathrm{S}>\mathrm{P}$ & & $\mathbf{L}>\mathrm{R} \quad 1$ & & & & & & \\
\hline & $\mathrm{S}<\mathrm{P} \quad 5$ & & $\mathrm{~L}<\mathrm{R} \quad 1$ & & & & & & \\
\hline \multirow{3}{*}{$\begin{array}{l}\text { single } \\
\text { occlusion } \\
\quad \mathrm{O}\end{array}$} & $\mathrm{O}=\mathrm{P} \quad 0$ & & $\mathrm{O}=\mathrm{S} \quad 0$ & & $\mathbf{L}=\mathbf{R} \quad 0$ & & & & \\
\hline & $\mathrm{O}>\mathrm{P} \quad 0$ & & $\mathrm{O}>\mathrm{S} \quad 0$ & & $\mathrm{~L}>\mathrm{R} 2$ & & & & \\
\hline & $\mathrm{O}<\mathrm{P} 22$ & & $O<S \quad 8$ & & $\mathrm{~L}<\mathrm{R} 2$ & & & & \\
\hline \multirow{3}{*}{$\begin{array}{l}\text { multiseg- } \\
\text { mental } \\
\text { occlusions } \\
\quad \text { MO }\end{array}$} & $\mathrm{MO}=\mathrm{P}$ & 0 & $\mathrm{MO}=\mathrm{S}$ & 0 & $\mathrm{MO}=\mathrm{O}$ & 0 & $\mathbf{L}=\mathrm{R} \quad 1$ & & \\
\hline & $\mathrm{MO}>\mathrm{P}$ & 0 & $\mathrm{MO}>\mathrm{S}$ & 0 & $\mathrm{MO}>\mathrm{O}$ & 0 & $\mathrm{~L}>\mathrm{R} 3$ & & \\
\hline & $\mathrm{MO}<\mathrm{P}$ & 4 & $\mathrm{MO}<\mathrm{S}$ & 7 & $\mathrm{MO}<\mathrm{O}$ & 9 & $\mathbf{L}<\mathrm{R} 3$ & & \\
\hline \multirow{3}{*}{$\begin{array}{l}\text { poor } \\
\text { run-off } \\
\text { PRO }\end{array}$} & $\mathrm{PRO}=\mathrm{P}$ & 0 & $\mathrm{PRO}=\mathrm{S}$ & 0 & $\mathrm{PRO}=\mathrm{O}$ & 0 & $\mathrm{PRO}=\mathrm{MO}$ & 0 & $\mathrm{~L}=\mathrm{R}$ \\
\hline & $\mathrm{PRO}>\mathrm{P}$ & 0 & $\mathrm{PRO}>\mathrm{S}$ & 0 & $\mathrm{PRO}>\mathrm{O}$ & 0 & $\mathrm{PRO}>\mathrm{MO}$ & 0 & $\mathrm{~L}>\mathrm{R} 3$ \\
\hline & $\mathrm{PRO}<\mathrm{P}$ & 7 & $\mathrm{PRO}<\mathrm{S}$ & 4 & $\mathrm{PRO}<\mathrm{O}$ & 1 & $\mathrm{PRO}<\mathrm{MO}$ & 4 & $\mathrm{~L}<\mathrm{R} 7$ \\
\hline
\end{tabular}

* The underlined numbers indicate equal values despite different angiographic diagnosis.

** The numbers between brackets indicate inverse relation of the worse leg.

$\mathbf{L}=$ Left $\quad \mathbf{R}=$ Right

$\square$ The table is diagonally symmetrical. 
Table X. Comparison of the parameter value P.R. of the legs within one patient related to the arteriographic diagnosis of the legs (15 types) $\square$.

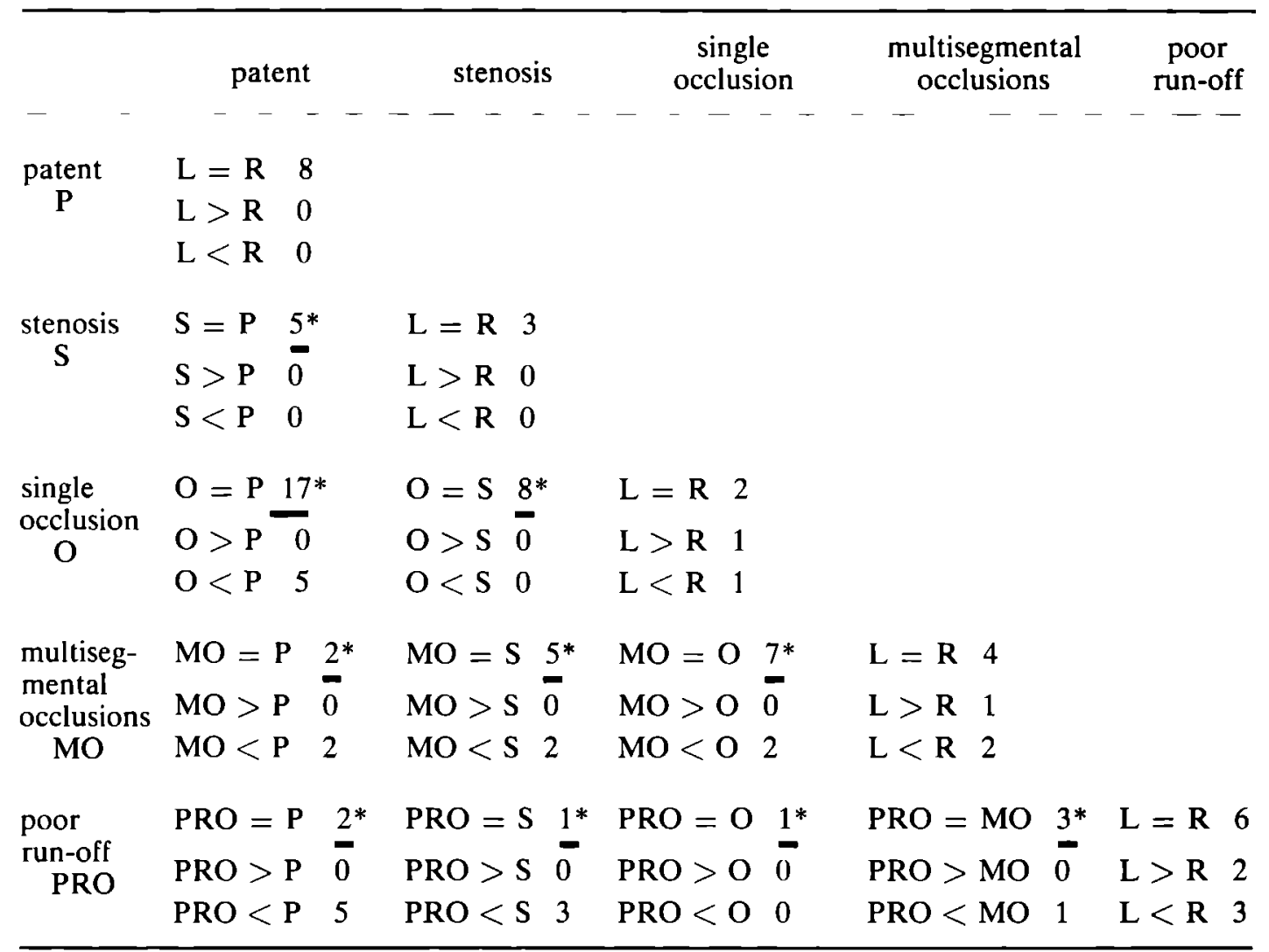

- The underlined numbers indicate equal values despite different angiographic diagnosis.

* The numbers between brackets indicate inverse relation of the worse leg.

$\mathbf{L}=$ Left $\quad \mathbf{R}=$ Right

$\square$ The table is diagonally symmetrical. 
Table XI. Comparison of 4 parameters related to condition difference of the legs within a subject.

\begin{tabular}{|c|c|c|c|c|c|c|}
\hline & \multicolumn{3}{|c|}{$\begin{array}{l}71 \text { subjects with different } \\
\text { condition of the legs }\end{array}$} & \multicolumn{3}{|c|}{$\begin{array}{l}33 \text { subjects with equal } \\
\text { condition of the legs }\end{array}$} \\
\hline & $\mathrm{pa}$ & $\begin{array}{l}\text { meter differe } \\
\text { of the legs }\end{array}$ & nces & pa & $\begin{array}{l}\text { eter diffe } \\
f \text { the leg }\end{array}$ & \\
\hline parameter & equal & $\begin{array}{c}\text { worse leg }> \\
\text { better leg }\end{array}$ & $\begin{array}{c}\text { worse leg }< \\
\text { better leg }\end{array}$ & equal & $\mathrm{L}>\mathrm{R}$ & $\mathrm{L}<\mathrm{R}$ \\
\hline- & & - & - & - & & \\
\hline$t_{\mathrm{a}}$ & 11 & 56 & 4 & 18 & 6 & 9 \\
\hline$t_{\mathrm{m}, 1 \mathrm{n}}$ & 11 & 49 & 11 & 9 & 13 & 11 \\
\hline P.I. & 0 & 0 & 71 & 6 & 11 & 16 \\
\hline P.R. & 51 & 0 & 20 & 23 & 4 & 6 \\
\hline
\end{tabular}

\subsection{Relationship between tracer parameters and arteriographic diagnosis in legs}

As mentioned in chapter III (Table l) the total number of legs was subdivided into 5 subgroups according to the angiographic diagnosis. As a result 208 legs corresponding to 104 patients were evaluated. Every subgroup was considered as being representative for a hypothetical population of the same type of leg.

For the purpose of the present discussion the fact that some patients have both legs in the same subgroup and others have the opposite leg in another subgroup was not taken into consideration. Our first purpose was to gain insight into the size of the relations. In figures 27,28 and 29 the relationship between the obtained parameter levels and the arteriographic diagnoses is illustrated. The dispersion is indicated in the figures by arrows symbolizing one standard deviation above and below the mean value.

Figures 27 and 28 demonstrate that there is an increasing $t_{1}$ as well as $t_{\text {max }}$ when angiographic diagnosis indicates more serious vascular disease, but there is a great overlap between the subgroups. From the data in figure 29 there is no doubt that the perfusion index appears to be the best parameter in differentiating between normal subjects and patients with more severe peripheral occlusive disease. 
Fig. 27: Relationship between the parameter $t_{1}$ and the angiographic diagnosis.

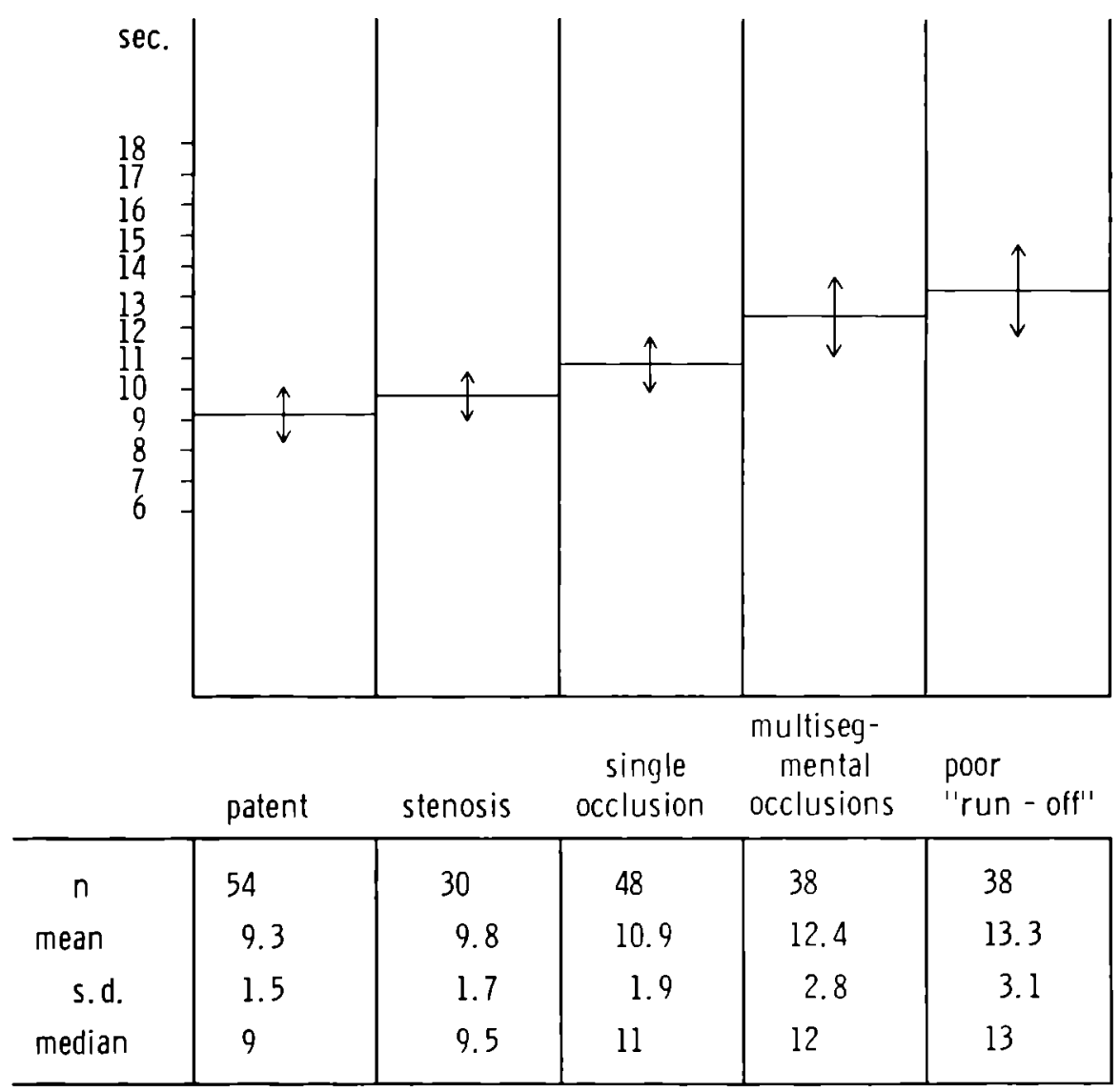


Fig. 28: Relationship between the parameter $\mathrm{t}_{\mathrm{mll}}$, and the angiographic diagnosis.

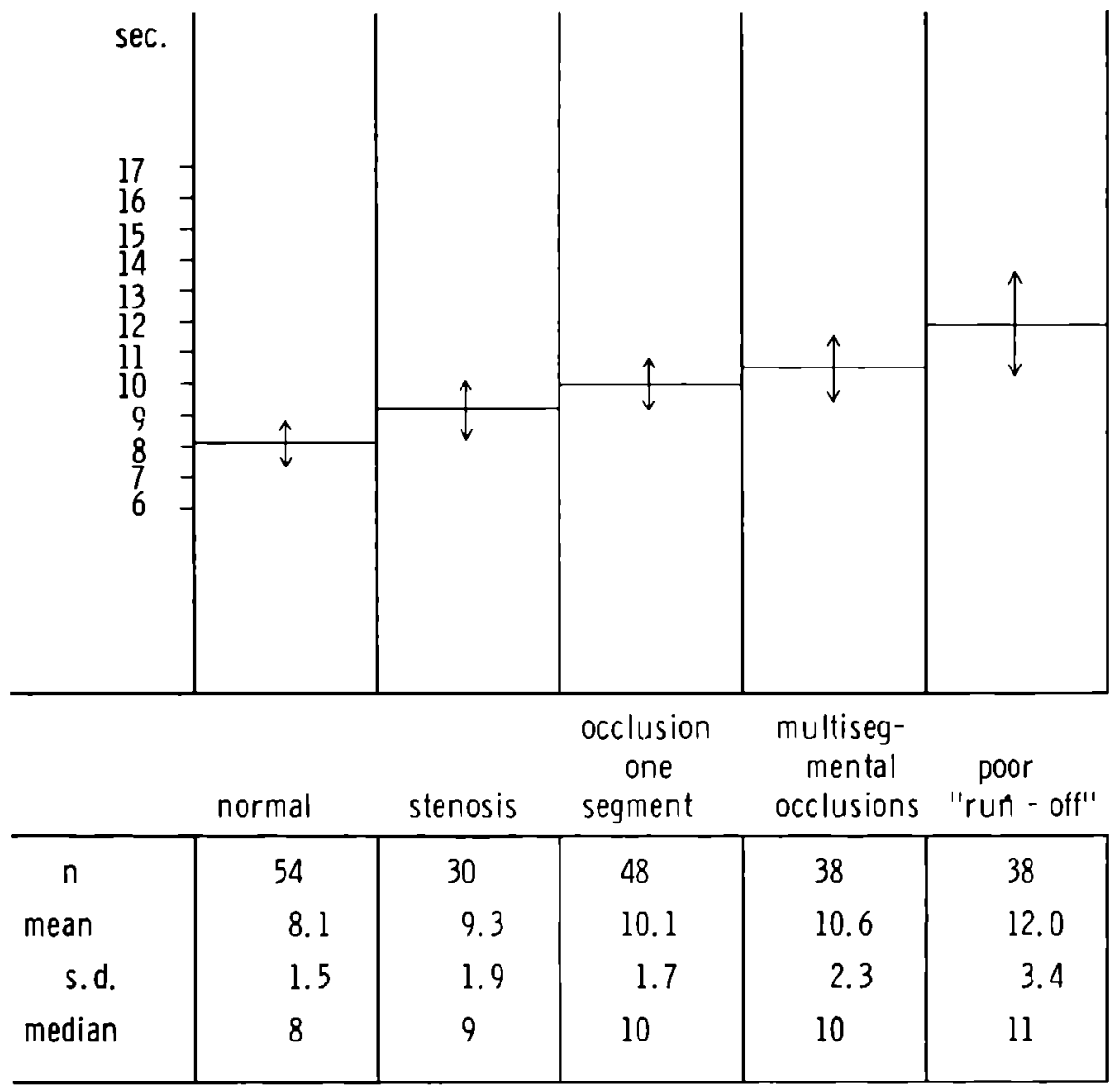


Fig. 29: Relationship between the perfusion index and the angiographic diagnosis.

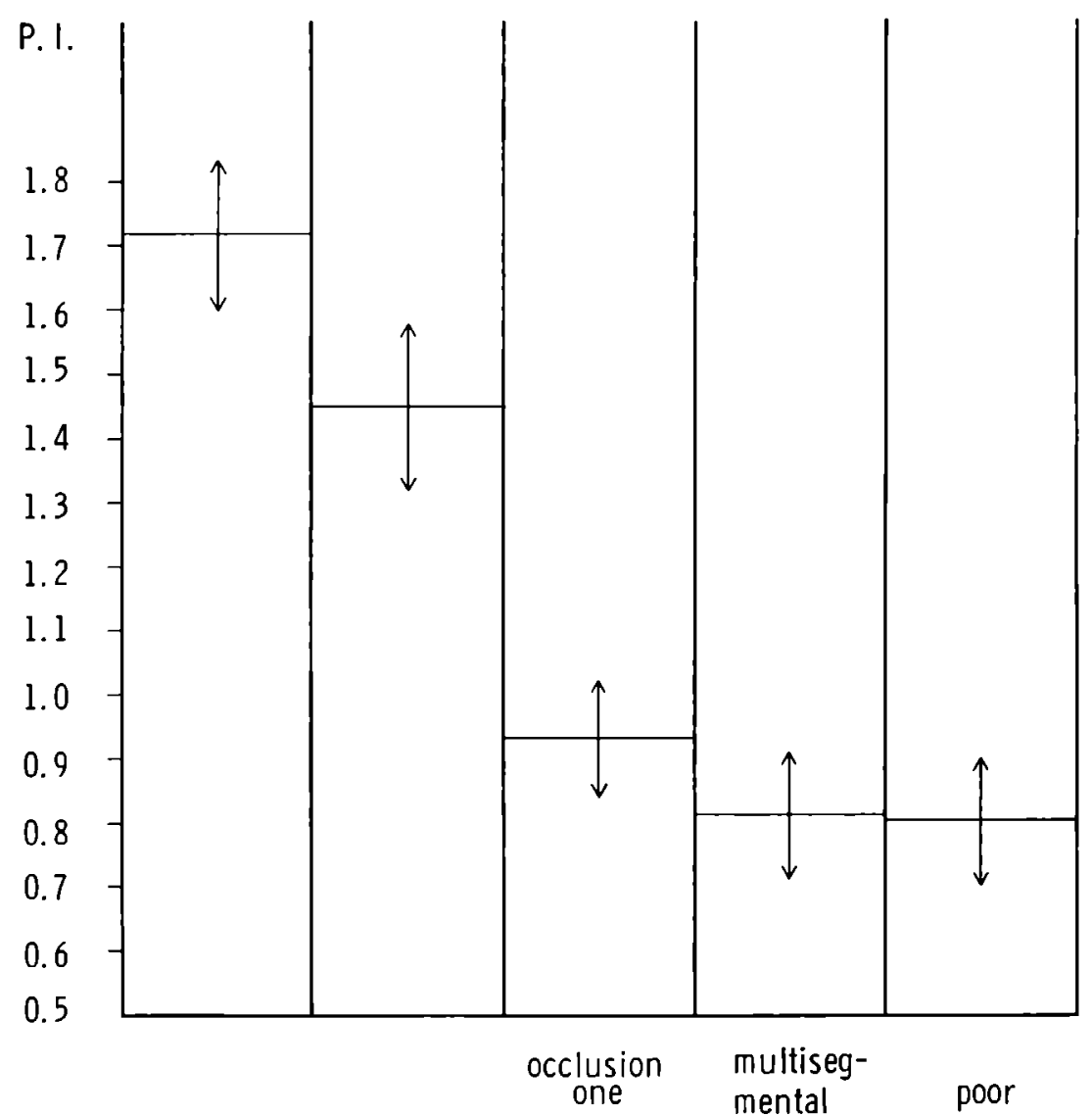

\begin{tabular}{|c|c|c|c|c|c|}
\hline & atent & stenosis & segment & $\begin{array}{l}\text { mental } \\
\text { occlusions }\end{array}$ & "run - off" \\
\hline$n$ & 54 & 30 & 48 & 38 & 38 \\
\hline mean & 1.74 & 1.46 & 0.93 & 0.82 & 0.81 \\
\hline s.d. & 0.25 & 0.26 & 0.18 & 0.20 & 0.20 \\
\hline median & 1.7 & 1.4 & 0.9 & 0.8 & 0.8 \\
\hline $\begin{array}{l}\text { frequency } \\
\text { of the pre- } \\
\text { sence of } \\
\text { peak activity } \\
\text { in the curve }\end{array}$ & $100 \%$ & $100 \%$ & $21 \%$ & $16 \%$ & $16 \%$ \\
\hline
\end{tabular}




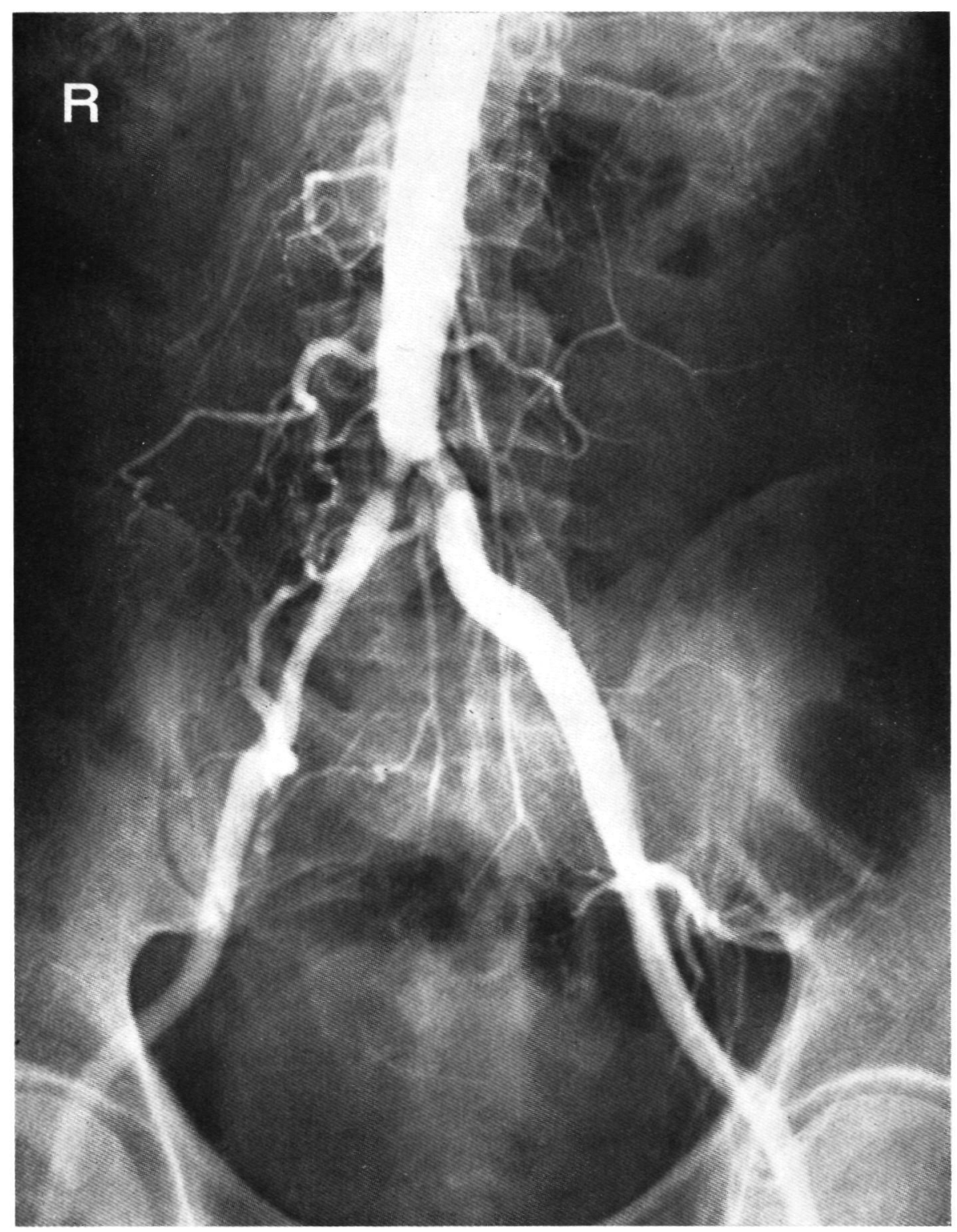

Fig. 30: Arteriogram of case report K. v. W., illustratig severe stenosis in right and left common iliac arteries. 


\subsubsection{Case report (K.v.W.)}

Absence of complaints does not always imply a patent vasculature as might be illustrated by the following case report (K.v.W.) of a 70-year-old man with a severe stenosis of the right and left common iliac arteries (Fig. 30). On the right a good collateral circulation was visualized angiographically. The patient's complaints were related exclusively to the right leg with pain after a walking distance of 100 meters without resting pain.

The tracer study performed prior to the angiogram demonstrated a small peak segment on the right side with a perfusion index of 1.2 but on the left peak activity was completely normal with a P.I. value of 2.0 (Fig. 31a). During surgical exploration the right common iliac artery appeared to be almost completely obstructed, but there was a stenosing arteriosclerotic plaque at the origin of the left common iliac artery. A dacron bifurcation bypass graft was placed, and 2 months after the vascular reconstruction the tracer study demonstrated normal peak activities in both legs with a P.I. value of 1.8 on the left and of 1.7 on the right (Fig. 31b).
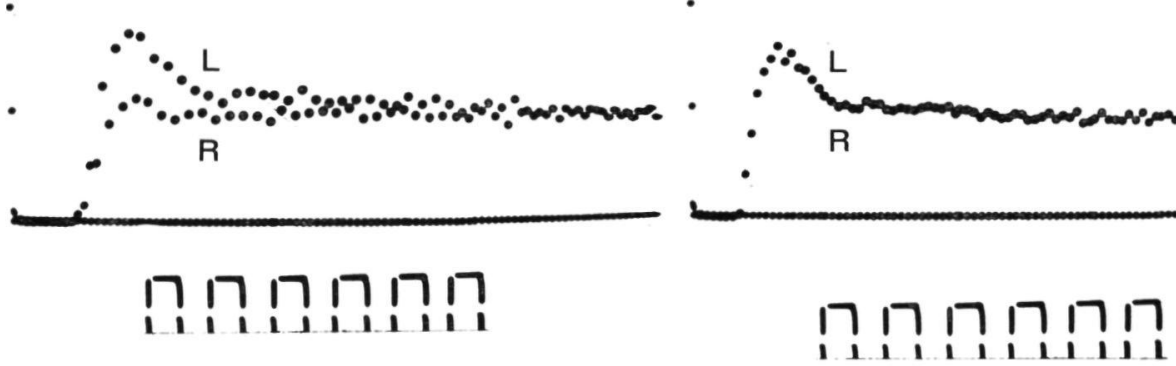

Fig. 31a: Activity-time curves of the tracer study of the same patient as in Fig. 30 before surgery. Note the small peak segment on the right side.

Fig. 31 b: Activity-time curves of the same patient after reconstructive surgery. Right and left curve almost superimpose. 


\subsubsection{Case report (A.v.d.K.)}

In patients with complaints suggestive of arterial disease, where the tracer study demonstrates normal symmetrical peak activity, the angiographic pictures would show patent vasculature. This may be illustrated by the case report (A.v.d.K.) of a 59-year-old patient with a one-year history of progressive pain in the hip region radiating to the thigh and knee after walking a distance of 300 meters. A vascular cause of the complaints was suspected and a tracer study was performed. A normal pattern of the curves was obtained with equal activity distribution of both legs resulting in a perfusion index value of 1.7 on the right side and 1.6 on the left side. These findings are compatible with a patent main arterial system without stenosis or occlusions. The angiographic control confirmed this diagnosis and the patient was referred to the neurologist for further evaluation.

\subsubsection{Case report (J.S.)}

The next case report (J.S.) demonstrates the importance of the opposite extremity acting as a control for the extremity under study. A 37-year-old man complained for three months of claudication starting in the right knee and radiating to the calf and foot after a walking distance of 25 meters. The onset coincided with the end of a period of hospitalization for treatment of pneumonia. On the day before his discharge from the hospital he developed acute pain in the right knee and lower leg. Because of his complaints a tracer study was performed demonstrating decreased peak activity on the right side with a P.I. value of 1.2 and a normal pattern on the left with a P.I. value of 2.2. Furthermore the activity distribution of the scintiphoto of the involved leg demonstrated poorly perfused medially localized muscles compared to the lateral part of the calf (Fig. 32). Three months later upon rehospitalization an angiographic study was initially interpreted as normal (Fig. 33). Due to his typical clinical history as well as the results of the tracer study, the radiographs were reviewed and a suspect image of the distal part of the popliteal artery was detected. A femoral angiogram was then performed. A detail of this study clearly demonstrated a substop compensated by an excellent collateral circulation of the knee arteries (Fig. 34). An attempted embolectomy utilizing a Fogarthy balloon catheter failed. Arteriotomy was necessary for the removal of an old organized thrombus mass. The thrombus partially obstructed the popliteal artery and extended to the origin of the lower leg arteries. A short saphenous vein bypass graft was inserted from the proximal to the distal popliteal artery. Two months after the reconstruction a tracer study control was performed. This demonstrated a normal activity distribution in both calves as well as normal peak activity curves resulting in a P.I. value of 1.6 (Fig. 35). The complaints of the patients were relieved completely. 

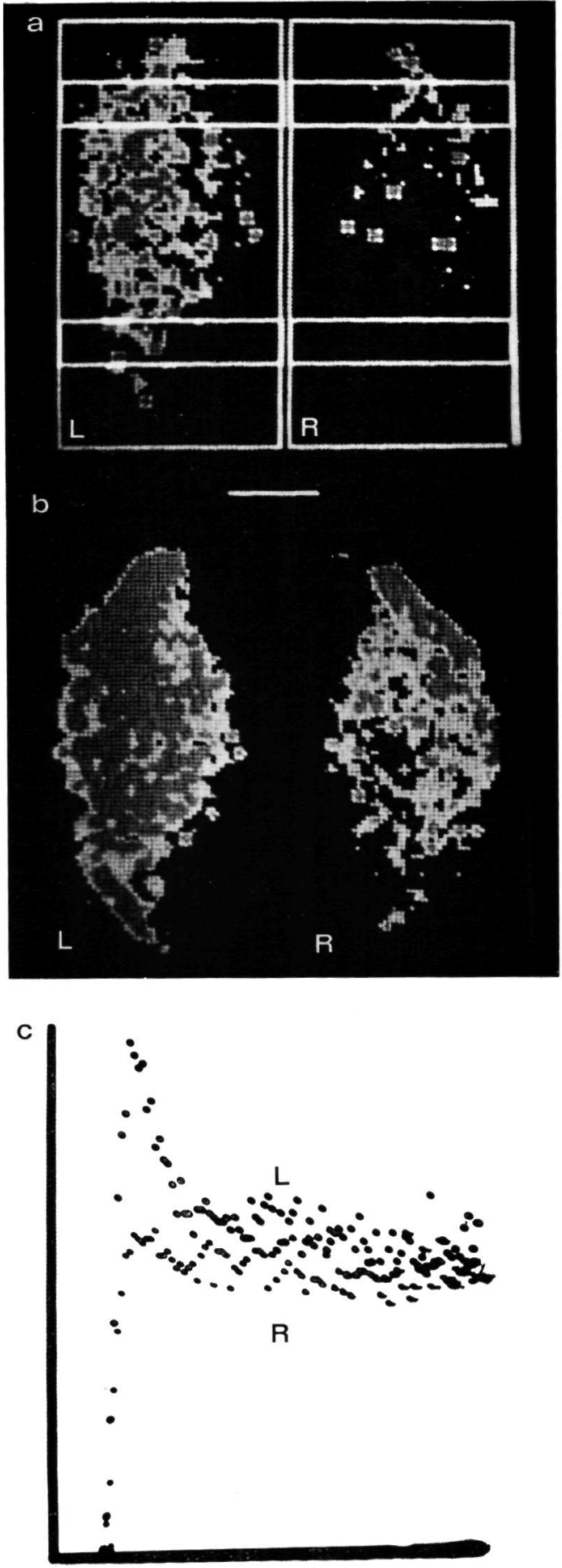

Fig. 32a: Black-and-white reproduction of color-coded scintiphotos of case report J.S. 20 seconds after injection.

Fig. 32b: Scintiphotos obtained 25 seconds after injection.

Note the lower activity in the medial part of the right calf.

Fig. 32c: Activity-time curve of the same patient. Left curve normal, right curve pathologic. 


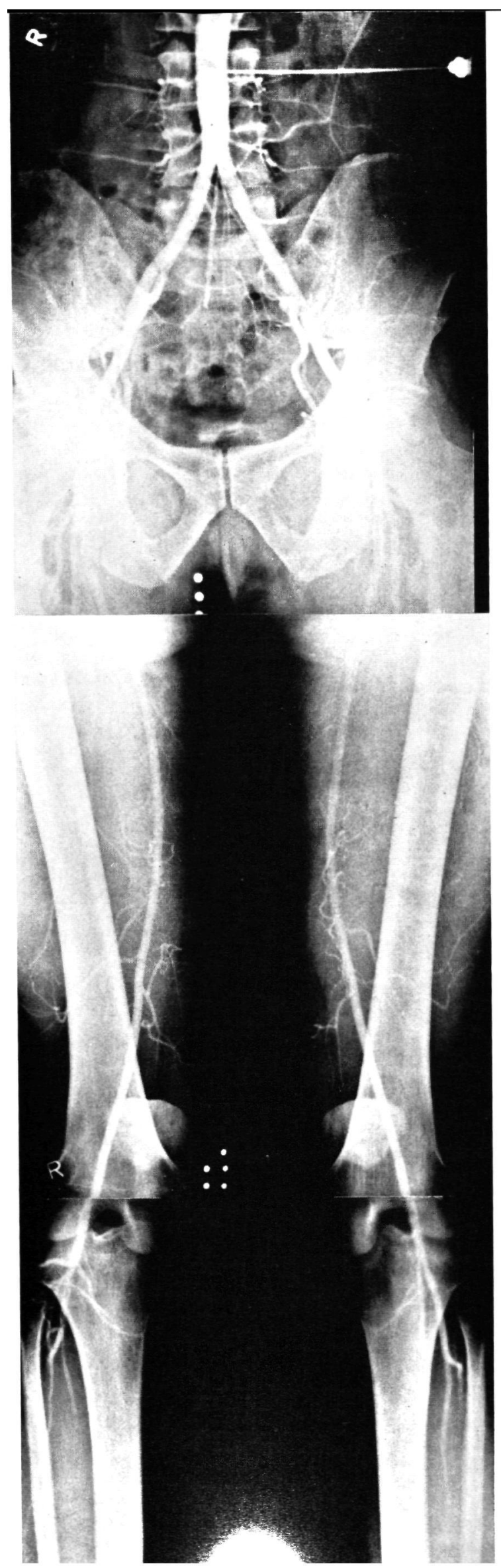

Fig. 33: Arteriogram of the same patient (J.S.), initially interpreted as patent. 


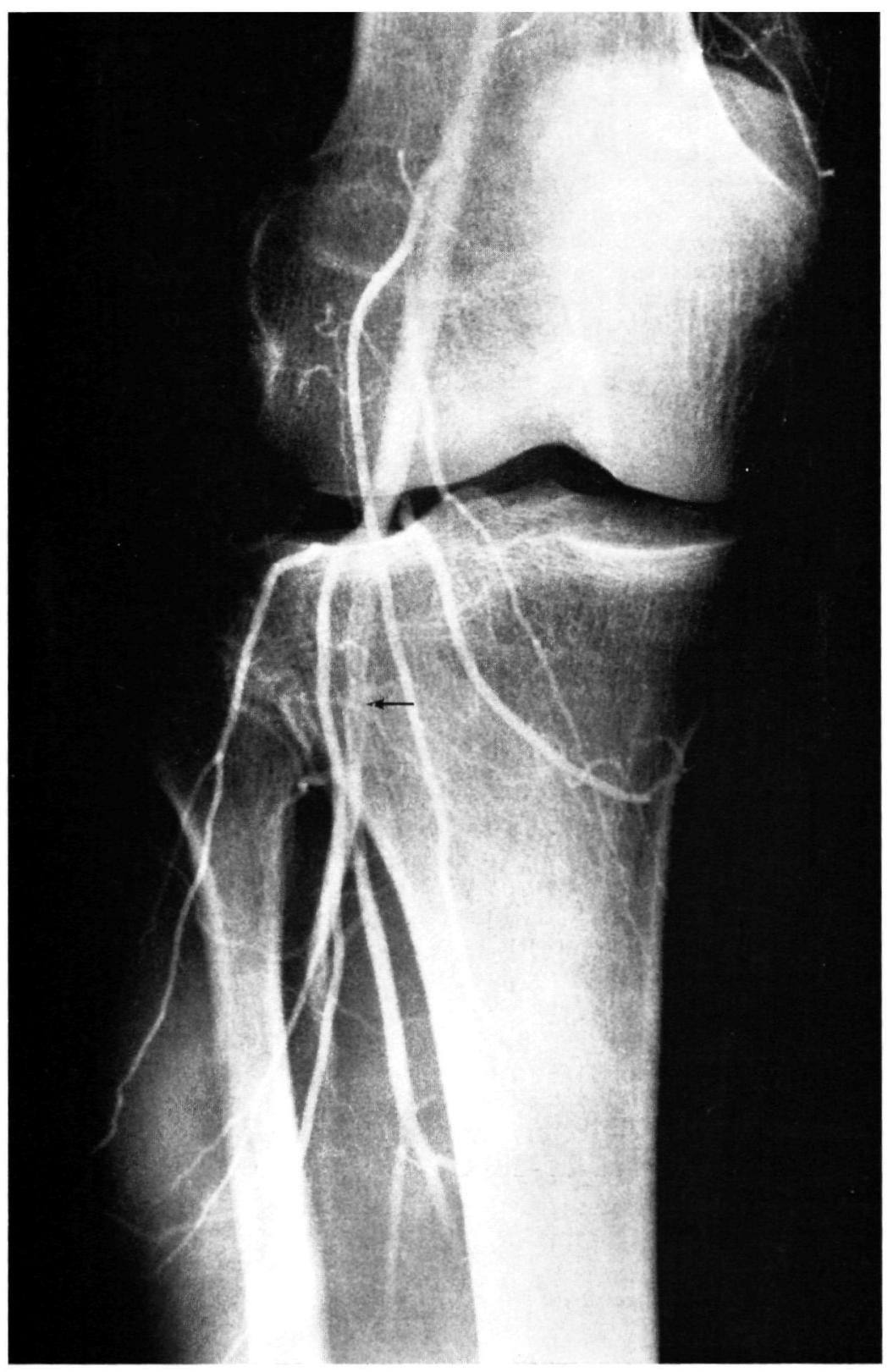

Fig. 34: Detail of the femoral arteriogram of the same patient (J.S.). Arrow indicates the substop in the distal popliteal artery. 

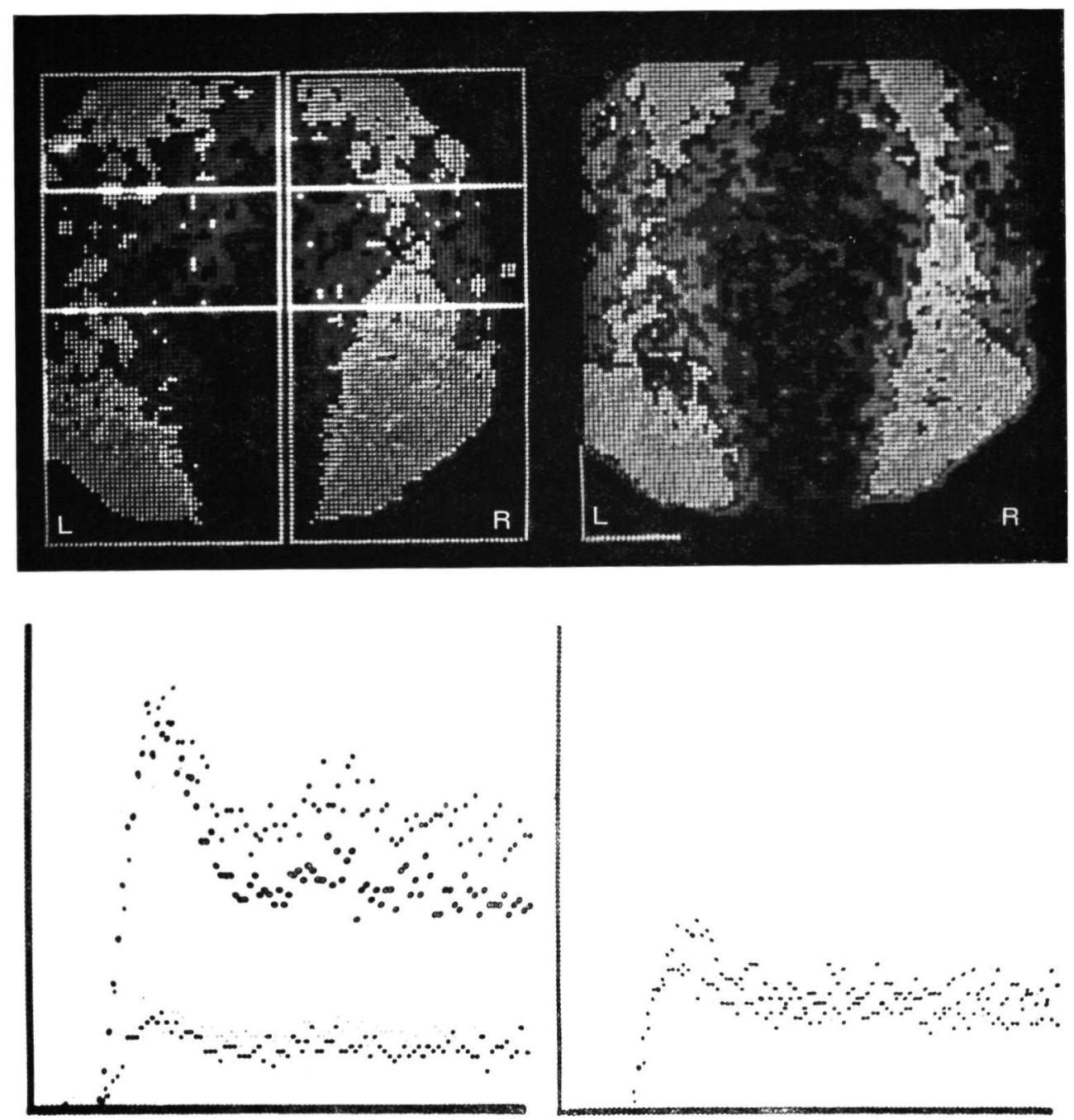

Fig. 35: Postoperative tracer study of patient J.S. Normal perfusion of both legs with normal curve patterns obtained from all the regions of interest. 
Generally speakıng the more serious the claudication complaints, the more advanced is the angiographic degree of disease The absence of complaints, however, does not necessarily indicate an angiographically patent leg But it is difficult to assess the hemody namic consequences strictly on the basis of the angıographic diagnosis (Table V) May et al (1963) reported that in an expcrimental study a lumen reduction of $80 \%$ was necessary to reduce the flow by $20 \%$ The clinical absence of claudication complaints in the case report K $v$ W correlated very well with the high peak activity of the left leg in the preoperatıve tracer study, indicatıng a fairly normal transport through the stenosed vessel

Clinically the diagnosis of arterial insufficiency in patients whose only complaınt is muscle weakness or pain durıng walkıng may present a difficulty (see case report $A \vee d K$ ) The tracer study in six cases served as a simple noninvasive test for the differentiation between true claudication due to peripheral arterial disease and symptomatic pain from other origins In other words the tracer study could be used as a screenıng test prior to angıgraphy

The rclationship between the angiographic diagnosis and the parameters within the same subject (Table VII, VIII and IX) demonstrated that in the majority of cases the values of $t_{1}$ and $t_{111}$, are higher in the worse leg In all patients the $P I$ value of the better leg was higher than that obtaned from the worse opposite leg, indicating that the P I value is the best parameter This is not contradicted by the fact that 31 patients with equal angiographic diagnosis did not have equal P I values It is expected that different P I values would be detected when different degrees of seventy within the same angiographic category were tested It is obvious that short occlusion of a vascular segment with excellent collateral circulation is functionally better than an occlusion of the whole vascular segment with poorly developed collaterds

The data mentioned above indicate that the perfusion index is the best parameter to differentiate between worse and better leg withın the same subject, as well as the best parameter in differentiatıng between normal subjects and patients

As a result the perfusion index might provide information to differentiate between opposite legs when the obtained values are compared within the same subject $A s$ an example let us consider a random individual from the patient group under study (104 patients) The P I value of the left leg in such a patient can either be equal or unequal to the P I value of the right leg Supposing that the P I value of the left leg is equal to that of the opposite leg, this implies that the chance for a didgnosis of the left leg to be the same as that of the right leg is equal to 1 On the other hand, if we assume the P I value of the leg to be unequal to that of the right leg, then the chance that the higher P I value corresponds to a better opposite leg is $71 / 98(72 \%)$, whereas the chance that both legs will have the same diagosis is $27 / 98(28 \%)$, and the chance that the 
leg with the highest P.I. value is worse than the opposite leg is $0 / 98(0 \%)$.

The P.I. values of legs with occlusive disease and patent run-off (subgroup III and IV) and of the subgroup with a poor run-off (subgroup V) are overlapping. In such cases the topographical distribution of the activity might be helpful in the differentiation between these subgroups. For instance, when there is an obvious delay in the perfusion of the distal part of the calf compared to the proximal part, this indicates lower leg artery occlusion.

The overlap of the P.I. values in the subgroup mentioned above reflects the arbitrariness of the 5 subgroup-division, correlating static angiographic pictures to their functional significance. For instance patients with a poor run-off but only minor arteriosclerotic changes of the main vascular tree would have a relatively high P.I. value, whereas a leg with multiple occlusive disease and a poorly developed collateral system would have a low perfusion index. The mean values in these subgroups accordingly do not deviate much from each other. Furthermore we must consider that the subgroups are composed of legs and not of patients.

\subsection{Treatment possibilities in the patients studied}

The changes in parameters in the case of complete surgical reconstruction, incomplete correction or other forms of treatment were evaluated as well as the behavior of the parameters when no treatment was performed. The evaluation resulted in the division of each subgroup into three categories.

Category A consisted of legs which underwent complete and successful surgical reconstruction.

Category B consisted of all legs not included under A or C. This category includes:

a) All legs which underwent only partial reconstruction such as in case of occlusive disease in the aorto-iliac as well as the femoro-popliteal segment, resulting in correction of only the proximal part of the arterial tree.

b) All legs which underwent surgical reconstruction with partial success. This might be due to a very small caliber of the saphenous vein utilized for the bypass procedure or to other reasons such as a very poor quality of the arterial wall.

c) A few legs which underwent sympathectomy.

Category $\mathrm{C}$ consisted of legs which did not undergo any kind of surgical treatment for one of the following reasons:

a) Arteriographically patent legs.

b) Treatment not urgently indicated at the time of the evaluation such as in patients with bilateral occlusions or stenosis with unilateral complaints. 
In such patients reconstruction was only performed on the painful or most painful leg.

c) Patients who were a poor surgical risk.

d) Some patients were technically inoperable.

\subsection{Changes in P.I. after management}

In the treated patients the P.I. values after surgery were compared to the preoperative values. The general behavior of the P.I. value is shown in Table XII. There is a very good result achieved in category A with increased P.I. values in $96 \%$. In category $B$ where only a partially successful treatment was possible there was an improvement in $57 \%$. In category $\mathrm{C}$ the obtained P.I. values were decreased in $57 \%$. This will be further discussed together with the more detailed study of the behavior of the parameters in the categories of each subgroup.

Table XII. Changes in perfusion index after management.

\begin{tabular}{|c|c|c|c|c|c|c|c|}
\hline & $\begin{array}{l}\text { number } \\
\text { of legs }\end{array}$ & equal & $\%$ & decreased & $\%$ & increased & $\%$ \\
\hline$\cdots-$ & $-\quad-$ & - & - & - & - & $-\quad-$ & $-\quad-$ \\
\hline category $A^{*}$ & 68 & 0 & 0 & 3 & 4 & 65 & 96 \\
\hline category B* & 28 & 8 & 29 & 4 & 14 & 16 & 57 \\
\hline category C* & 76 & 17 & 22 & 43 & 57 & 16 & 21 \\
\hline
\end{tabular}

* For definition of category see 5.11 .

\subsection{Surgical treatment in relation to the parameter values in each subgroup}

In Tables XIII, XIV and XV as well as in figures 36, 37, 38, 39 and 40 the parameter values are compared before and subsequent to possible treatment in the categories A, B and C of each subgroup. When adequate observations in the subgroup were available, systematic differences between the values of the parameters before and after surgery were analyzed utilizing the sign test.

In the patent subgroup the untreated category $C$ showed a $t_{111: x}$ value increased from $8.2 \mathrm{sec}$ to $9.1 \mathrm{sec}(0.01<p \leqslant 0.05)$. On the other hand the P.I. value dropped from 1.78 to $1.67(0.01<p \leqslant 0.05)$ as illustrated in Fig. 36. In all the cases peak activity persisted, indicating that the lower values obtained do 
Table XIII. Behavior of parameter $\mathrm{t}_{\mathrm{it}}$ in category A, B and C of every subgroup (see text).

$\curvearrowright \quad$ Arteriographic Diagnosis

\begin{tabular}{|c|c|c|c|c|c|c|c|c|c|c|}
\hline & \multirow[b]{2}{*}{$n$} & \multicolumn{2}{|c|}{ before } & \multicolumn{2}{|c|}{ after } & \multicolumn{2}{|c|}{ before-after } & \multirow[b]{2}{*}{ equal } & \multirow[b]{2}{*}{ decreased } & \multirow[b]{2}{*}{ increas } \\
\hline & & mean & sd & mean & sd & mean & sd & & & \\
\hline Patent & & & & & & & & & & \\
\hline category A & 2 & 8.0 & 1.4 & 10.0 & 2.8 & -2.0 & 4.2 & 0 & 1 & 1 \\
\hline B & 1 & 10. & & 11. & & -1 & & 0 & 0 & 1 \\
\hline $\mathrm{C}$ & 35 & 9.4 & 1.4 & 9.4 & 1.6 & 0.0 & 1.0 & 16 & 9 & 10 \\
\hline
\end{tabular}

sign - test

p-value $\square$

Stenosis

category

$\begin{array}{rrrrrrrrrr}\text { A } & 13 & 9.1 & 1.1 & 9.0 & 1.4 & 0.1 & 1.8 & 1 & 5 \\ \text { B } & 0 & & & & & & & & \\ \text { C } & 15 & 10.5 & 2.0 & 10.9 & 2.1 & -0.5 & 2.0 & 2 & 6\end{array}$

Single occlusion category A 34

$\begin{array}{rrrrr}\mathrm{A} & 34 & 10.9 & 2.0 & 9.9 \\ \mathrm{C} & 2 & 13.0 & 1.4 & 12.0 \\ & 10.5 & 1.5 & 10.8\end{array}$

1.6
0.0
1.5

$\begin{array}{rrr}1.0 & 2.0 & 10 \\ 1.0 & 1.4 & 1 \\ -0.3 & 1.7 & 4\end{array}$

19
1
3

Multiple occlusions

\begin{tabular}{rrrrrrrrrrrr} 
category A & 16 & 11.7 & 1.9 & 9.8 & 1.3 & 1.9 & 1.7 & 2 & 13 & 1 & $p \leqslant 0.01$ \\
B & 8 & 12.6 & 2.3 & 11.4 & 1.9 & 1.3 & 1.8 & 2 & 5 & 1 & $0.10<p \leqslant 0.25$ \\
C & 8 & 10.4 & 1.7 & 10.6 & 2.3 & -0.3 & 1.5 & 3 & 2 & 3 & NS \\
& & & & & & & & & & & \\
Poor run-off & & & & & & & & & & & NS \\
category A & 2 & 10.5 & 0.7 & 10.0 & 0.0 & 0.5 & 0.7 & 1 & 1 & 0 & NS \\
B & 16 & 12.3 & 1.7 & 12.1 & 1.3 & 0.3 & 1.3 & 6 & 6 & 4 & 2 \\
C & 6 & 11.8 & 1.7 & 12.2 & 1.7 & -0.3 & 1.0 & 3 & 1 & 2 & \\
\hline
\end{tabular}


Table XIV. Behavior of parameter $\mathrm{t}_{\mathrm{III}}$ in category A, B and C of every subgroup (see text).

Arteriographic Diagnosis

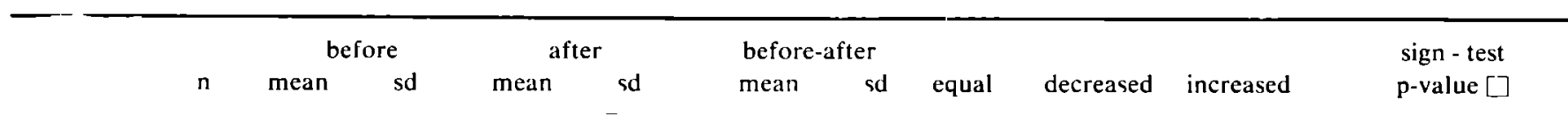

Patent

$\begin{array}{rrrrrrrrrrr}\text { category A } & 2 & 7.5 & 0.7 & 9.5 & 0.7 & -2.0 & 1.4 & 0 & 0 & 2 \\ \text { B } & 1 & 8.0 & & 11.0 & & -3.0 & & 0 & 0 & 1 \\ \text { C } & 36 & 8.2 & 1.5 & 9.1 & 2.2 & -0.8 & 2.3 & 8 & 7 & 21\end{array}$

$0.01<\mathrm{p} \leqslant 0.05$

Stenosis

category A

$\begin{array}{ll}\text { A } & 13 \\ \text { B } & 0 \\ \text { C } & 16\end{array}$

1.0

7.7

2.0

1

2.2

9.9

1.8

$-0.2$

2.8

Single occlusion

category A 34

$\begin{array}{rrrrrrrr}\mathrm{A} & 34 & 10.2 & 1.8 & 8.9 & 2.0 & 1.4 & 2.4 \\ \mathrm{~B} & 2 & 8.5 & 0.7 & 11.5 & 2.1 & -3.0 & 1.4 \\ \mathrm{C} & 10 & 10.1 & 1.3 & 9.9 & 1.9 & 0.2 & 1.1\end{array}$

Multiple occlusions

$\begin{array}{llll}\text { category A } & 17 & 10.8 & 2.7\end{array}$

$\begin{array}{rrrr}\text { A } & 17 & 10.8 \\ \text { C } & 8 & 10.6 & 2.7\end{array}$

2.7

$\begin{array}{rr}9.4 & 1.4 \\ 11.0 & 2.2 \\ 10.3 & 5.2\end{array}$

$\begin{array}{rrr}1.4 & 2.7 & 6 \\ -0.4 & 2.3 & 1 \\ -0.8 & 2.4 & 0\end{array}$

23
0
5

8
2

4

$0.01<\mathrm{p} \leqslant 0.05$

NS

Poor run-off

\begin{tabular}{rrrrrrrrrrrrr} 
& category A & 2 & 11.0 & 4.2 & 8.0 & 0.0 & 3.0 & 4.2 & 1 & 1 & 0 & \\
& $\mathrm{~B}$ & 17 & 11.4 & 2.9 & 11.6 & 3.2 & -0.2 & 3.3 & 2 & 8 & 7 & NS \\
$\stackrel{\mathrm{C}}{0}$ & 6 & 11.5 & 2.7 & 11.7 & 2.7 & -0.2 & 4.5 & 1 & 2 & 3 & NS \\
\hline
\end{tabular}

$\square$ Meaning of symbols: blank = not statistically compared

NS = not significant 
Table $X V$. Behavior of parameter P.I. in category A, B and $\mathrm{C}$ of every subgroup (see text).

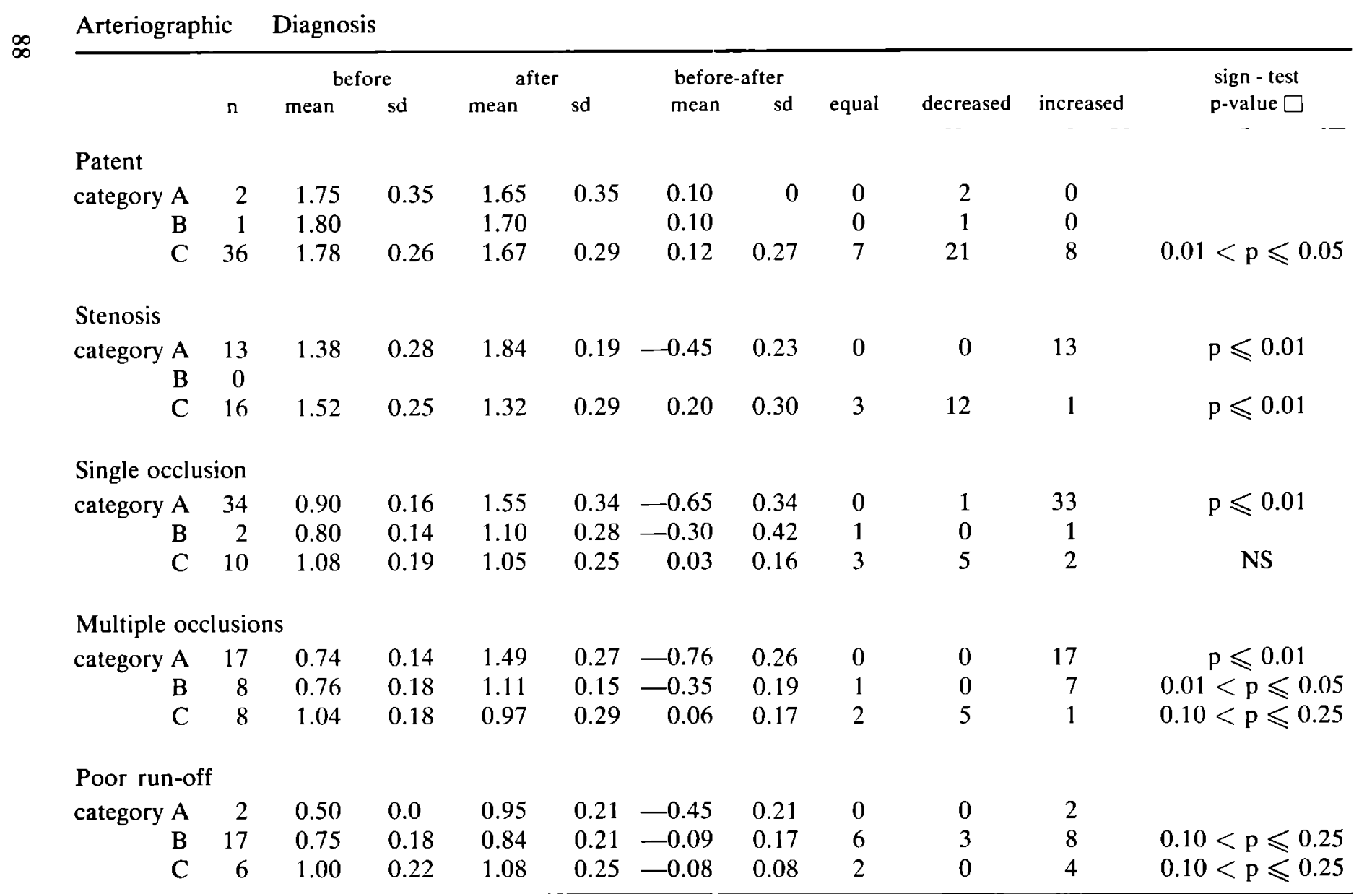


Fig. 36: Effects of eventual treatment on the perfusion index in the patent subgroup.

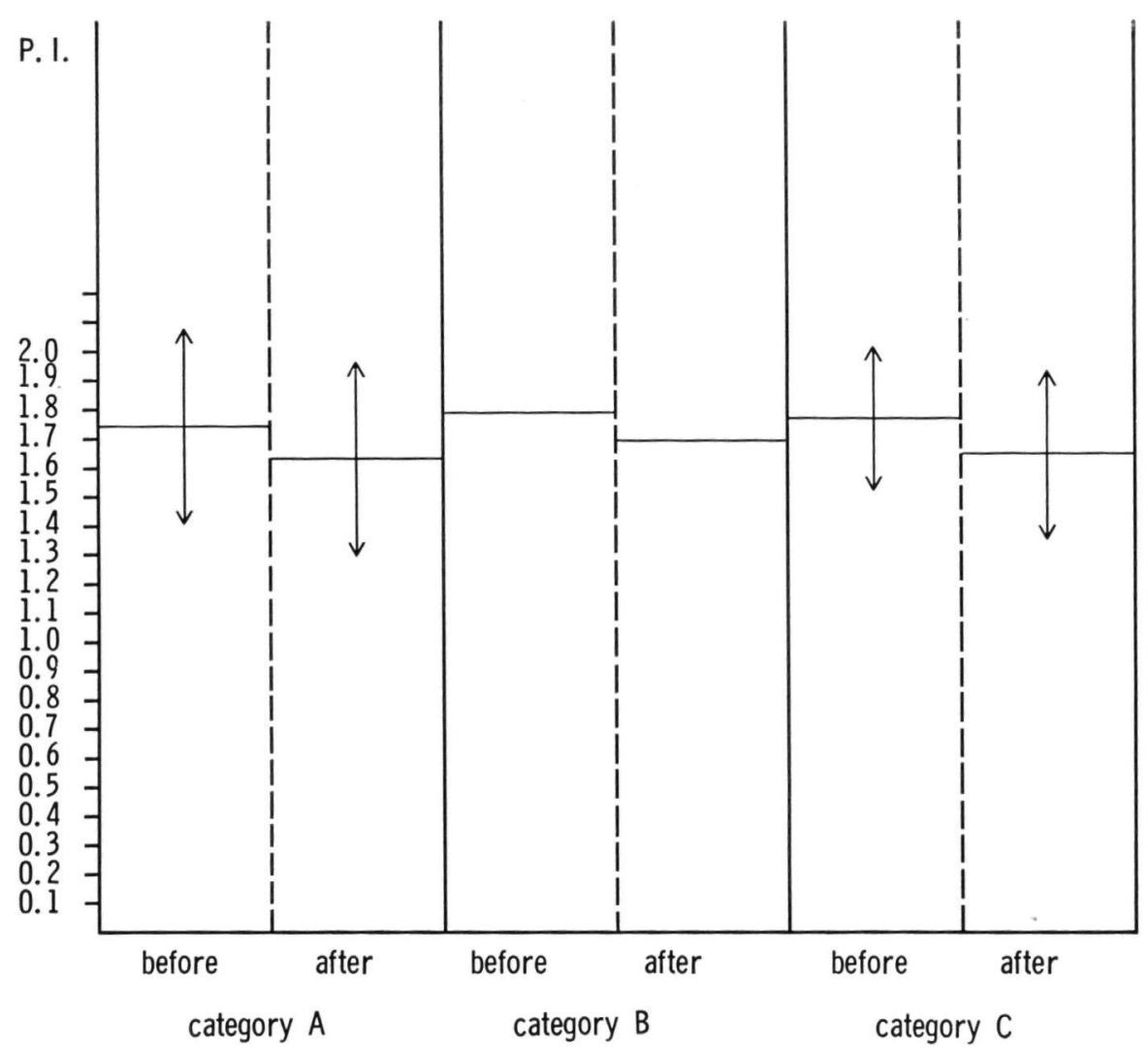

not imply pathologic curve patterns. Worth mentioning is that two legs angiographically diagnosed patent underwent surgical reconstruction. In both cases the common iliac artery showed angiographically arteriosclerotic changes without significant stenosis. However, while operating on the opposite side, the surgeon discovered that the arteriosclerotic changes were more serious than implied by the angiogram. A bypass prosthesis was therefore inserted at the bifurcation.

In the legs with stenosis successful vascular reconstruction (category A) 
Fig. 37: Effects of the eventual treatment on the perfusion index of the subgroup stenosis.

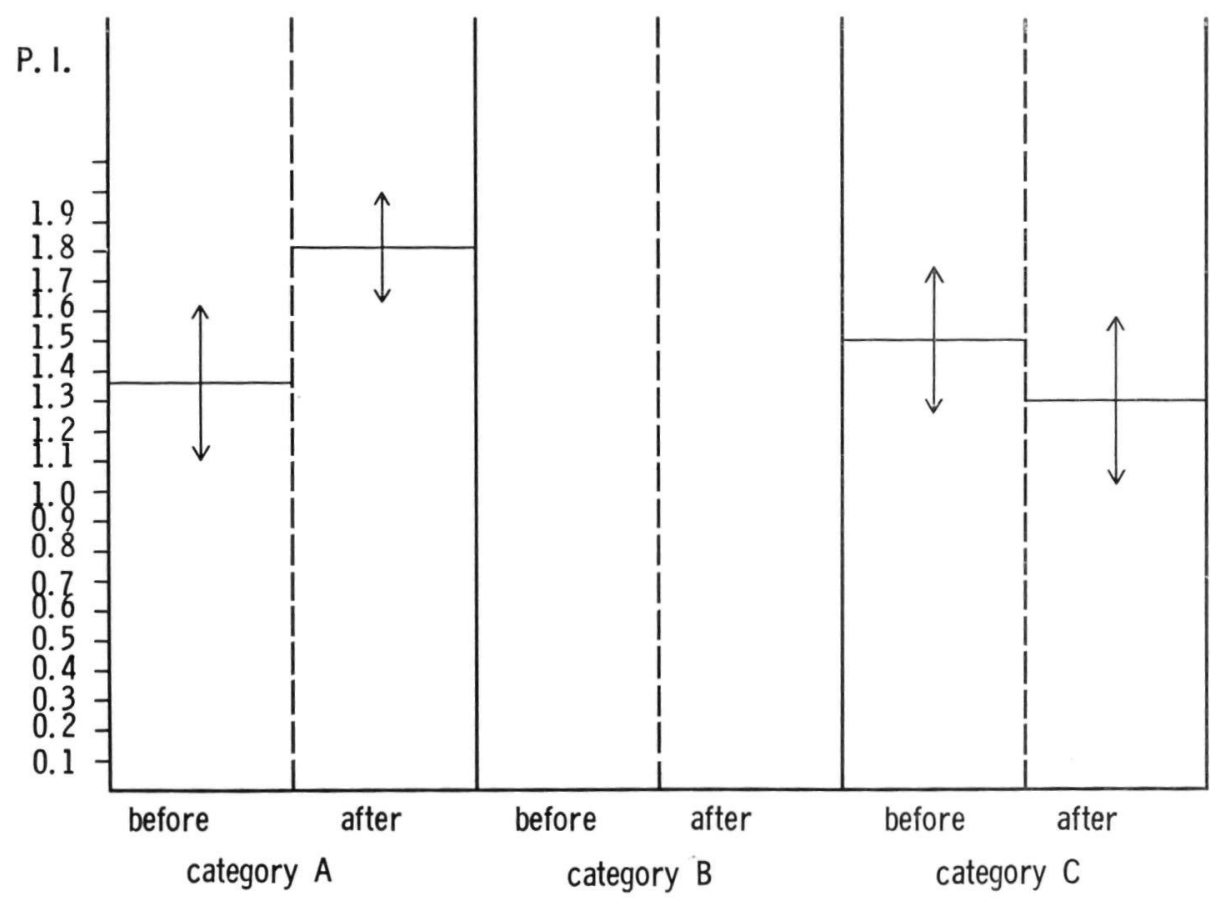

resulted in a significant decrease of $t_{\max }$ from $8.9 \mathrm{sec}$ to $7.7 \mathrm{sec}(0.01<\mathrm{p}$ $\leqslant 0.05)$, and in a systematic rise of the obtained P.I. values from 1.38 to 1.84 $(\mathrm{p} \leqslant 0.01$ ) (Fig. 37). In category $\mathrm{C}$ a systematically lower P.I. value was obtained, changing from 1.52 to 1.32 ( $\mathrm{p} \leqslant 0.01$ ). In all cases except two, peak activity was present. In these two cases the peak activity disappeared after treatment of the opposite leg, resulting in a poor activity distribution and a pathologic curve pattern. This will be illustrated in case report V.A. below (5.14.1).

In subgroup III (legs with an occlusion of a single segment) it was obvious that in category $A$ a systematic decrease in $t_{a}$ and $t_{\max }$ was obtained: $t_{a}$ from $10.9 \mathrm{sec}$ to $9.9 \mathrm{sec}(\mathrm{p} \leqslant 0.01)$, and $\mathrm{t}_{\max }$ from $10.2 \mathrm{sec}$ to $8.9 \mathrm{sec}(0.01<$ $\mathrm{p} \leqslant 0.05)$. On the other hand the P.I. value increased in 33 out of 34 legs from 
Fig. 38: Effects of eventual treatment on the perfusion index in the subgroup single segment occlusion.

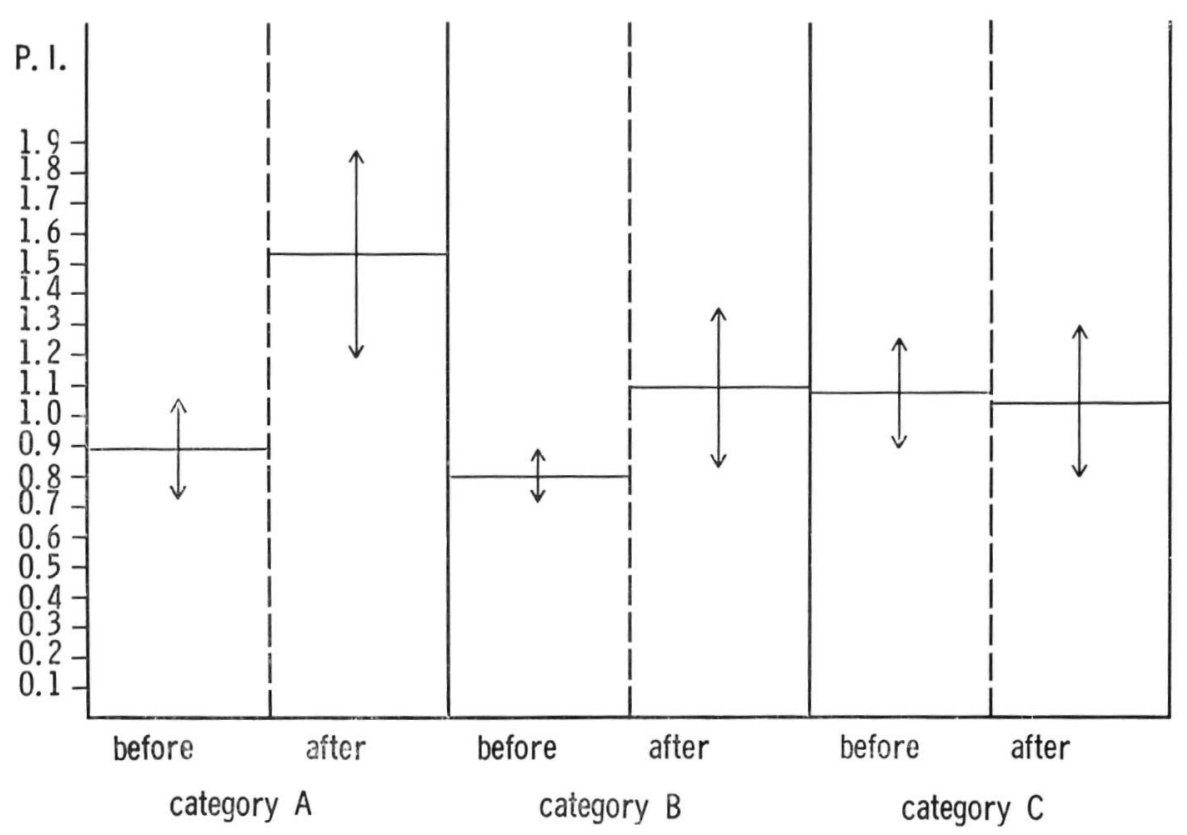

0.90 to 1.55 ( $\mathrm{p} \leqslant 0.01$ ). Category $\mathrm{B}$ was too small for statistical analysis, and in category $\mathrm{C}$ no significant changes were observed (see Fig. 38 as well).

In subgroup IV (consisting of legs with multisegmental occlusions or stenosis) similar findings as in subgroup III were obtained. Here $\mathrm{t}_{\mathrm{a}}$ declined from $11.7 \mathrm{sec}$ to $9.8 \mathrm{sec}(\mathrm{p} \leqslant 0.01)$ in category $\mathrm{A}$ and from $12.6 \mathrm{sec}$ to $11.4 \mathrm{sec}(0.10<$ $\mathrm{p} \leqslant 0.25)$ in category $\mathrm{B}$. The $\mathrm{t}_{\max }$ decreased from $10.8 \mathrm{sec}$ to $9.4 \mathrm{sec}(0.05<$ $\mathrm{p} \leqslant 0.10)$ in category $\mathrm{A}$, with no significant changes in category $\mathrm{B}$, whereas there was a rise in the P.I. value in category $\mathrm{A}$ from 0.74 to $1.49(\mathrm{p} \leqslant 0.01)$, and in category B from 0.76 to $1.11(0.01<\mathrm{p} \leqslant 0.05)$ (Fig. 39). No significant change was observed in category $\mathrm{C}(0.10<\mathrm{p} \leqslant 0.05)$.

In the legs with poor run-off (subgroup $\mathrm{V}$ ) the number of observations in category A was very small, whereas there were no clearly significant changes present in category B as well as in category C (Fig. 40). 
Fig. 39: Effects of eventual treatment on the perfusion index in the subgroup multisegmental occlusions.

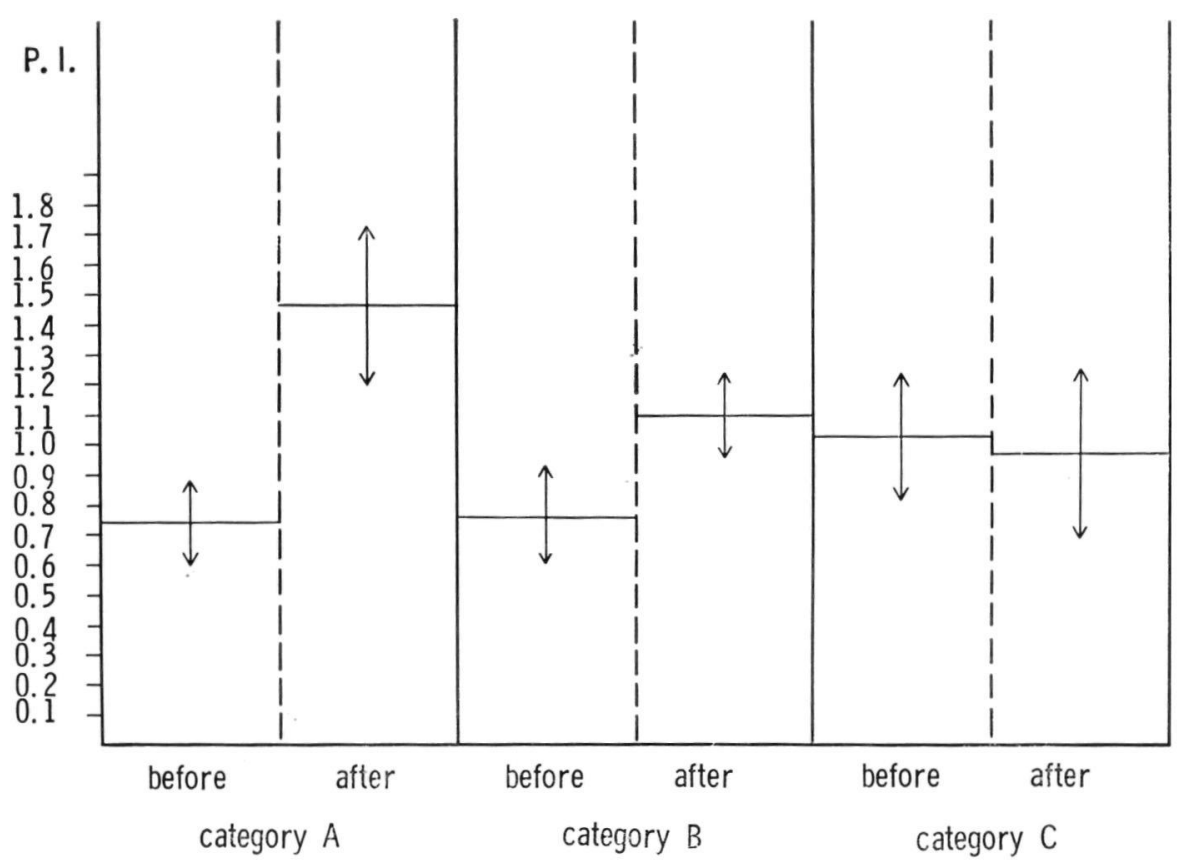

Fig. 40: Effects of eventual treatment on the perfusion index in the subgroup: poor run-off.

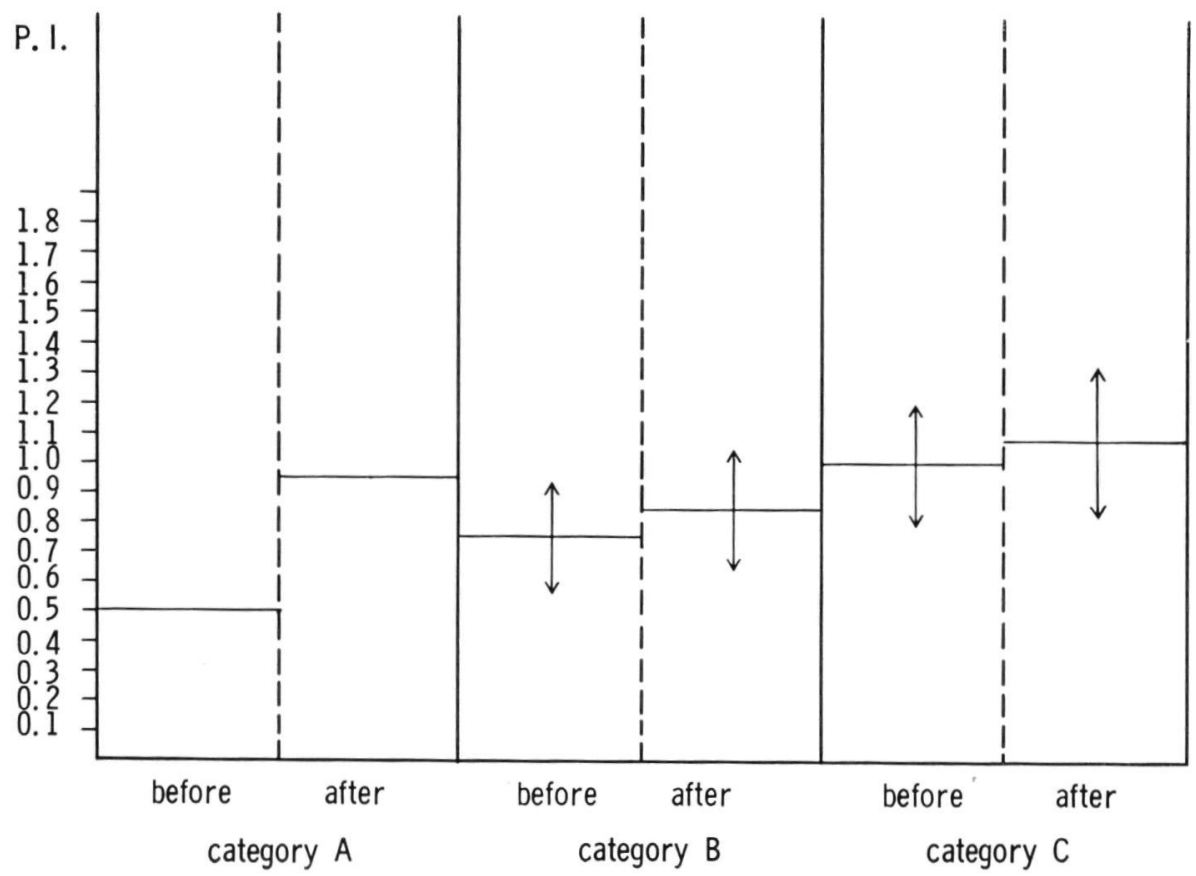




\subsubsection{Case report (V.A.)}

As mentioned above (5.13) the peak activity disappeared after treatment of the opposite leg in two cases of subgroup II.

This is illustrated by the following case report of a 47 -year-old man (V.A.) with an occlusion of the left superficial femoral artery and a stenosis in Hunter's canal on the right. Four weeks after reconstruction of the left side with a saphenous vein bypass graft claudication appeared in the right leg. Two weeks later the tracer study was repeated showing a normal activity distribution and curve pattern on the left, but an absent peak activity on the right. A control angiogram confirmed the occlusion of the femoral artery at the previous stenotic place During surgical exploration an old black blood clot was removed and a vein bypass was inserted.

\subsubsection{Case report (P.R.)}

The next case report demonstrates the compensatıng function of the collateral circulation in a leg with an occlusion of a main arterial channel as well as the usefulness of the tracer study in evaluating the function and confirming the patency of a bypass graft.

A 57-year-old man (P.R ) presented with a non-healıng pseudoarthrosis of the tibia and fibula of his left leg two years after a traffıc accident. Earlier there was a history of claudication complaints on the same side, and because of absence of any healıng tendency this was thought to be related to the impaired leg perfusion. The angıogram demonstrated occlusion of both superfical femoral arteries. A femoro-popliteal vein bypass graft was inserted on the fractured side, and the patıent was able to walk utılızing special orthopedic foot gear. However, after more than a year the fracture had not healed Some doubt on the function of the bypass contraindicated orthopedic correction of the pseudoarthrosis. Utılızıng the gamma camera system, the tracer study demonstrated a normal peak activity on the right with a P.I. value of 1.7 , in spite of the angiographic pathology. In the fractured leg the perfusion was very poor with a delay in the arrival of the activity (Fig. 41) and a pathologic slowly rising curve with a low plateau. The P.I value was 06 as compatible with an occlusion of the applied bypass graft (Fig. 42). This was confirmed by a femoral anglogram demonstrating an occlusion with a length of two $\mathrm{cm}$ in the distal anastomosis (Fig. 43) A new bypass graft was applied and 5 weeks after the operation the tracer study was repeated, demonstratıng a definite improvement of the perfusion with a P.I value rising to 1.2. That this is compatible with a functioning bypass is clearly visualızed on the serial ımages of the activity 


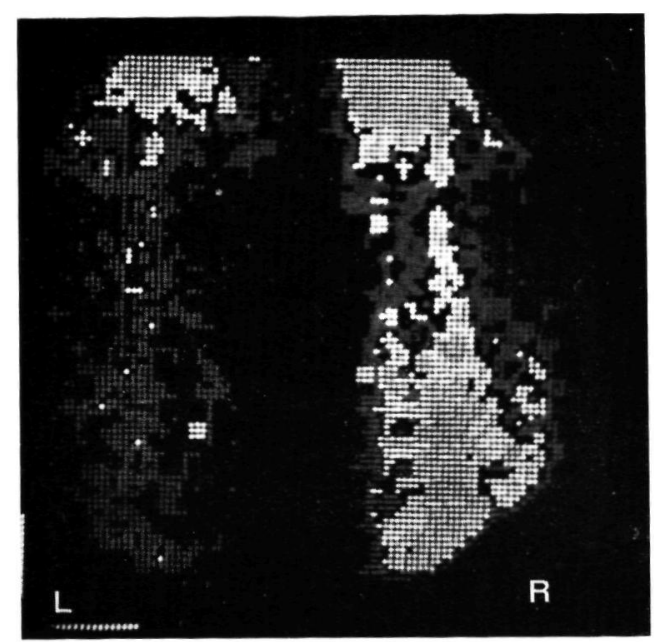

Fig. 41: Black-and-white reproduction of color-coded scintiphotos of patient P.R., demonstrating pathologic perfusion of loft calf.

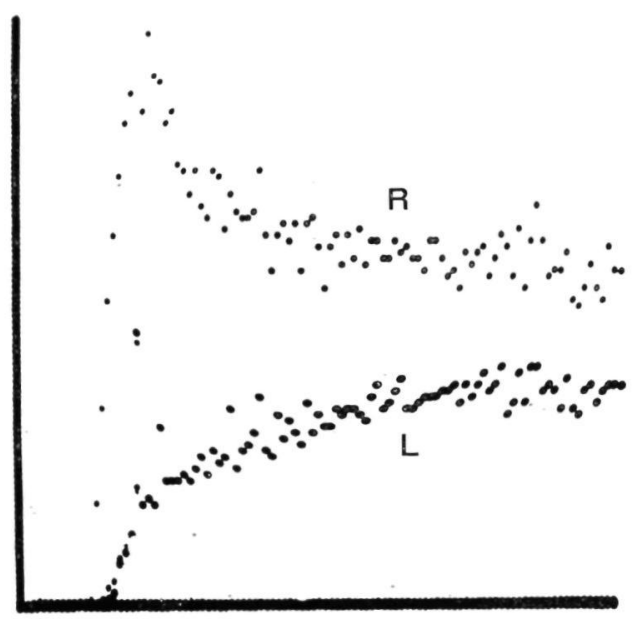

Fig. 42: Activity-time curves of the same patient. Note the peak activity in the curve obtained from the compensating right leg and the ascending pathologic curve of the left leg.

distribution. Both legs demonstrate an excellent perfusion of the distal muscles of both thighs and both calves with a slight delay in the left calf. On the scintiphotos the different pathways of the medially located vein bypass graft and the centrally located collaterals in the popliteal region of the left leg are clearly outlined (Fig. 44). With small areas of interest covering the bypass and the collateral pathways separately the activity turnover data could be obtained. A high peak activity curve pattern with a low plateau was obtained from the bypass region, and a relatively small peak with a high plateau was obtained from the region perfused by the collaterals (Fig. 45). 


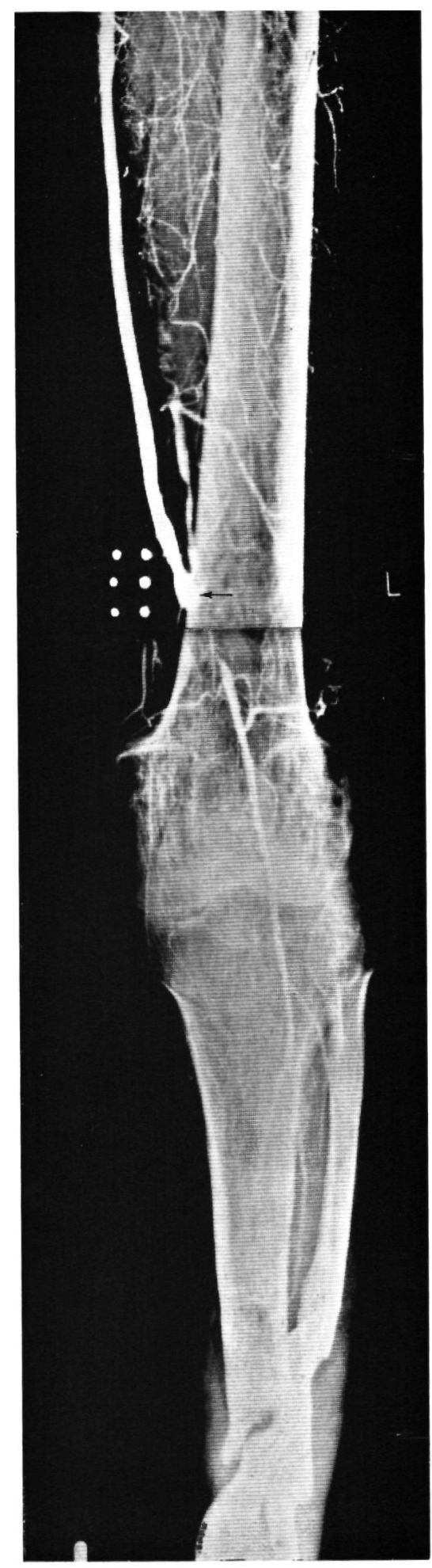

Fig. 43: Postoperative angiogram of the same patient as in Fig. 42.

Occlusion of the venous bypass graft indicated by arrow. 

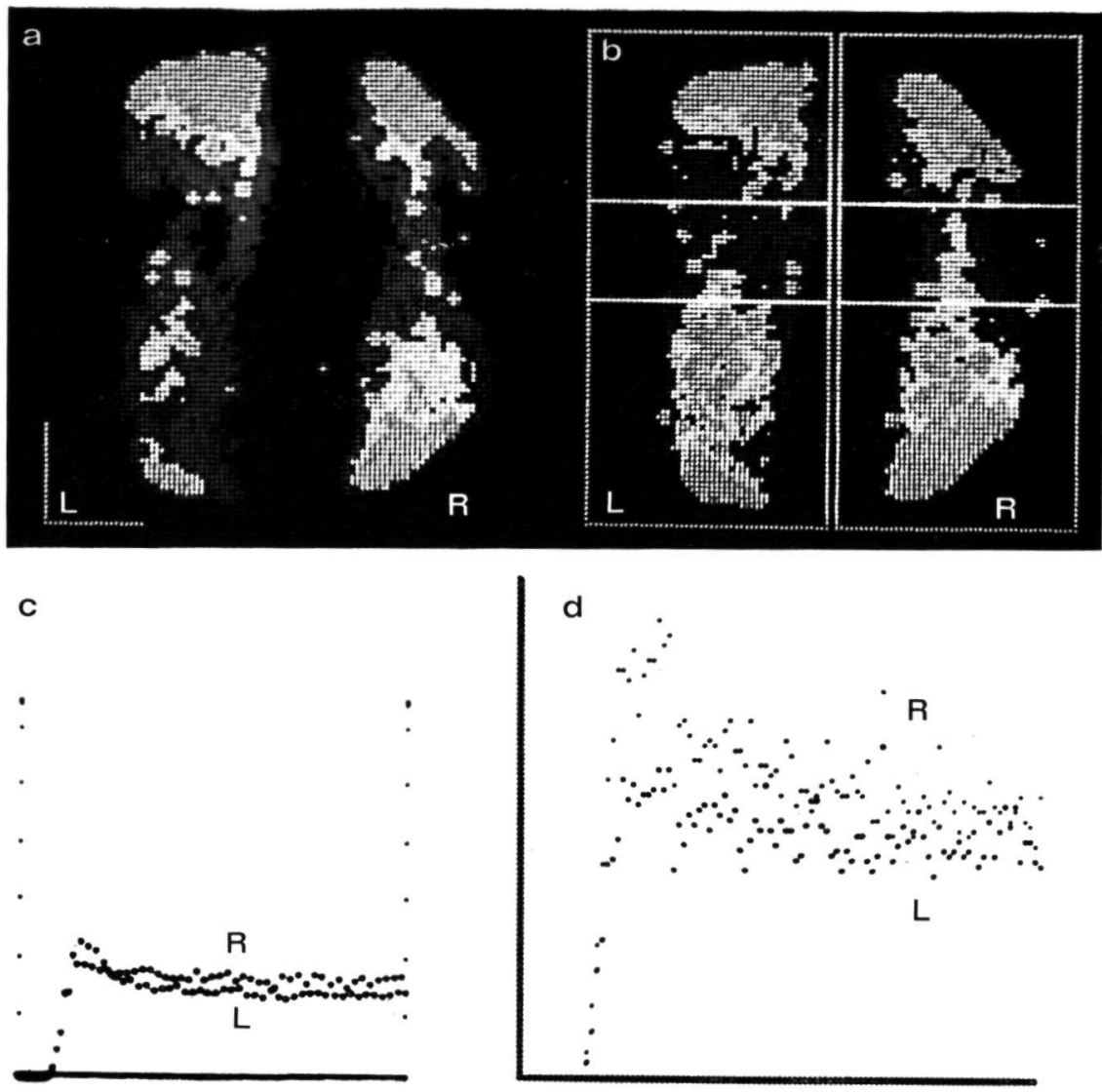

d

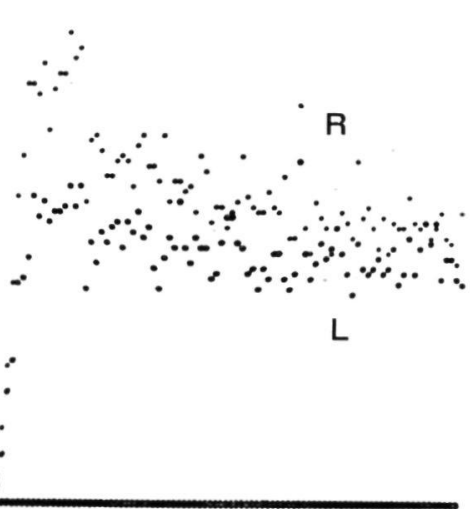

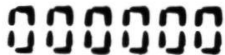

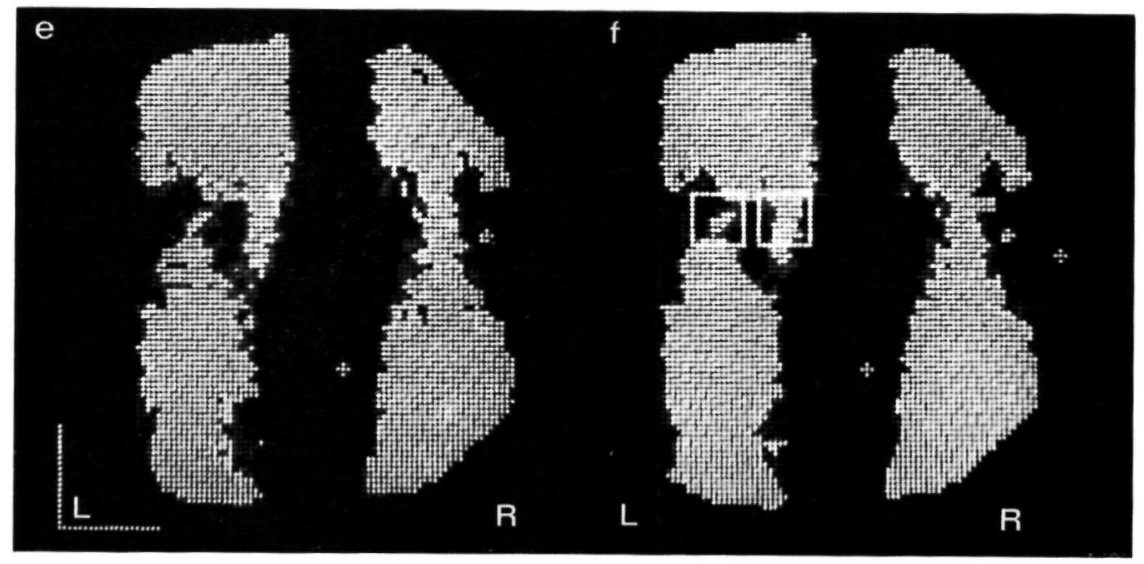

Fig. 44: Tracer study after the second operation of the same patient (P.R.). Note the improvement in the perfusion on the scintiphotos $a, b$, e and $f$. Normalization of the activitytime curves: $\mathrm{c}$ and $\mathrm{d}$ ( $\mathrm{c}$ is activity curve recorded from the data-processor, where as $\mathrm{d}$ is recorded from the computer monitor). Scintiphoto f demonstrates two areas of interest, one of the bypass and the other of the collateral area. 


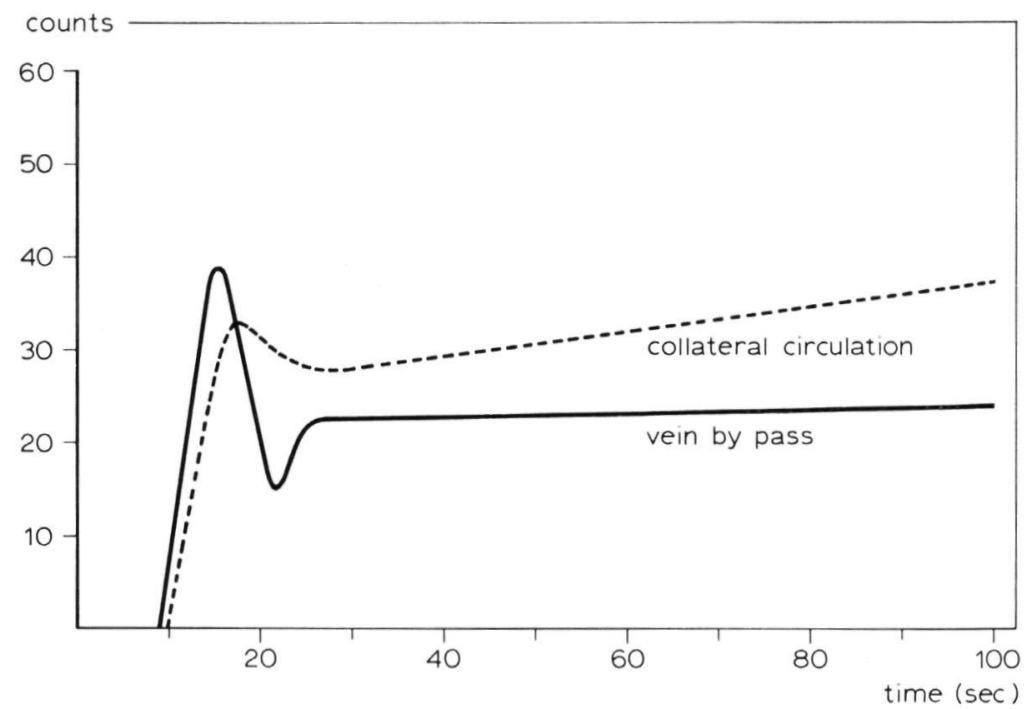

Fig. 45: Graphic representation of the printed-out counts of the two areas of interest shown in Fig. $44 \mathrm{f}$.

\subsubsection{Case report (O.-C.)}

In the subgroup with a poor run-off it was very difficult to obtain satisfactory surgical results. When only partial reconstruction was performed, it was sometimes very difficult to decide whether a bypass graft was functioning or not, as might be illustrated by the following case report.

A 66-year-old woman (O.-C.) with claudication complaints in both legs for several months as well as nocturnal resting pain in the right leg demonstrated on the tracer study a very poor activity distribution in both legs as well as pathologic curve patterns, more pronounced in the right leg (Fig. 46a). The angiogram correlated very well with these findings, demonstrating diffuse arteriosclerotic changes of the aorto-iliac arterial segments. There was also total occlusion of both superficial femoral arteries and arteriosclerotic tibial artery systems with stenosis in both legs. Because of the more serious complaints on the right, only this side was explored, demonstrating incomplete occlusion of the popliteal artery due to a very thick intimal core. The available vein bypass was unfortunately very short, resulting in a grafting procedure from the distal to the proximal popliteal artery and followed by a closed thromboendarterectomy of the superficial femoral artery. After two months the patient still complained of claudication, and clinically the bypass appeared to be occluded. A repeated tracer study again demonstrated pathologic curve patterns obtained 

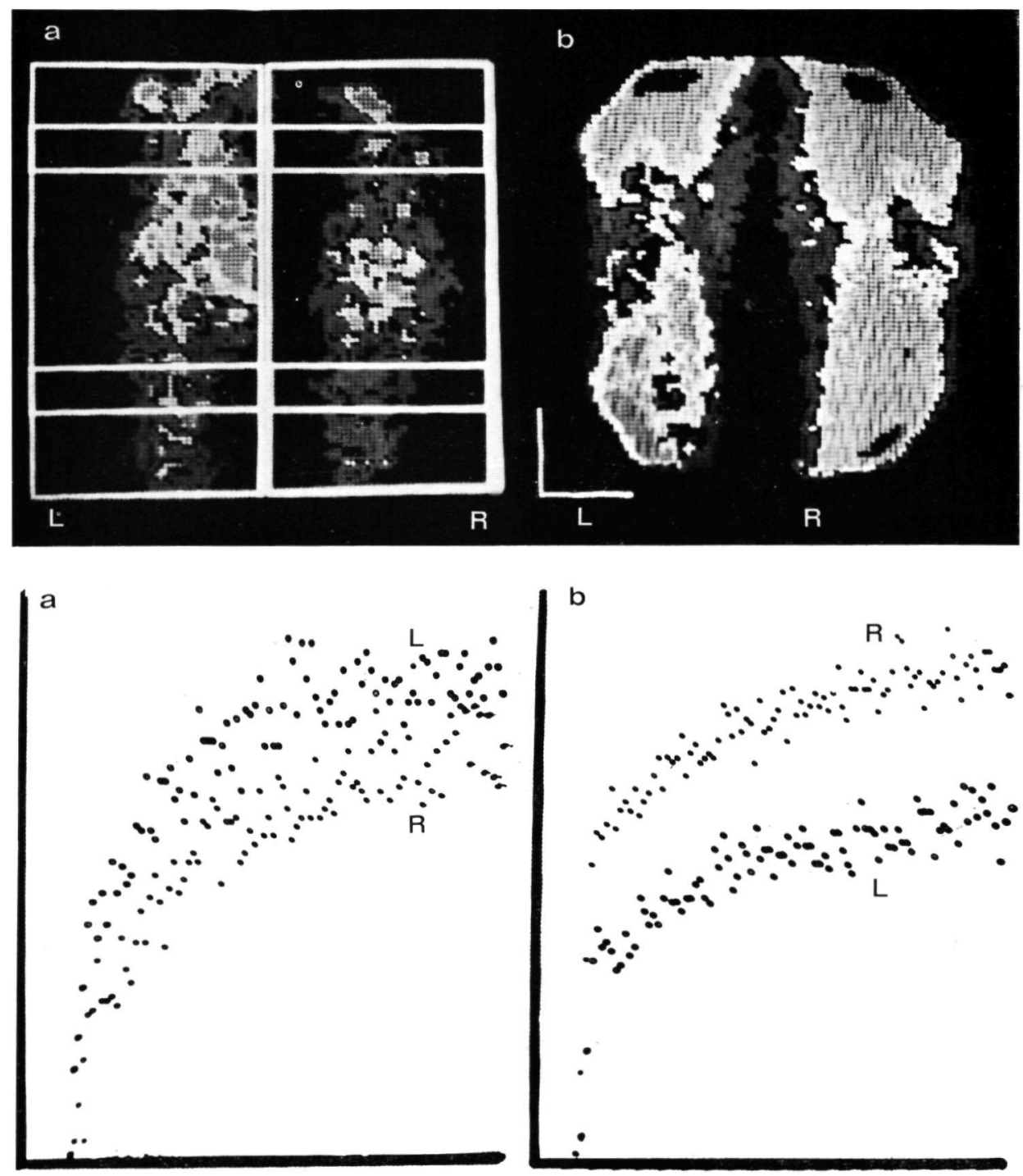

- a
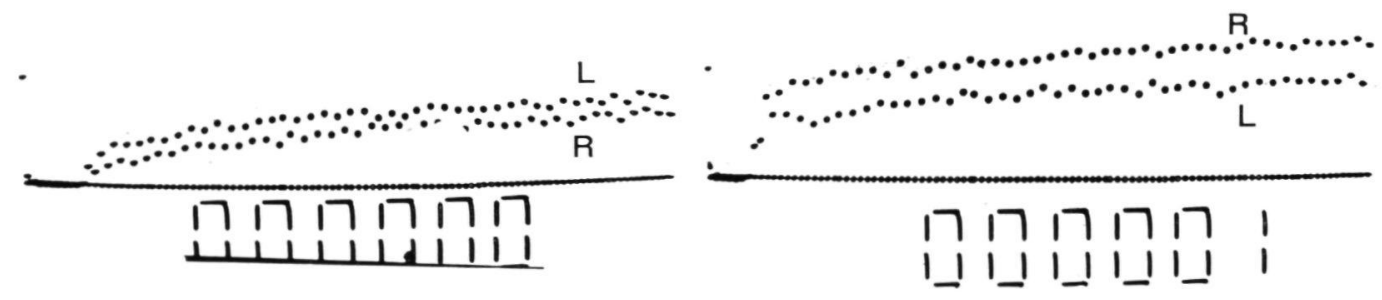
$<$

Fig. 46a: Tracer study of case repo:t O-C. Poor activity distribution in both legs, more pronounced on the right side.

Fig. 46b: Postoperative tracer study of the same patient. Note slight improvement of activity perfusion in the right $\mathrm{lcg}$ compared to the left.
Fig. 47: Postoperative angiogram of the right leg demonstrating stenotic proximal anastomosis (indicated by arrow).

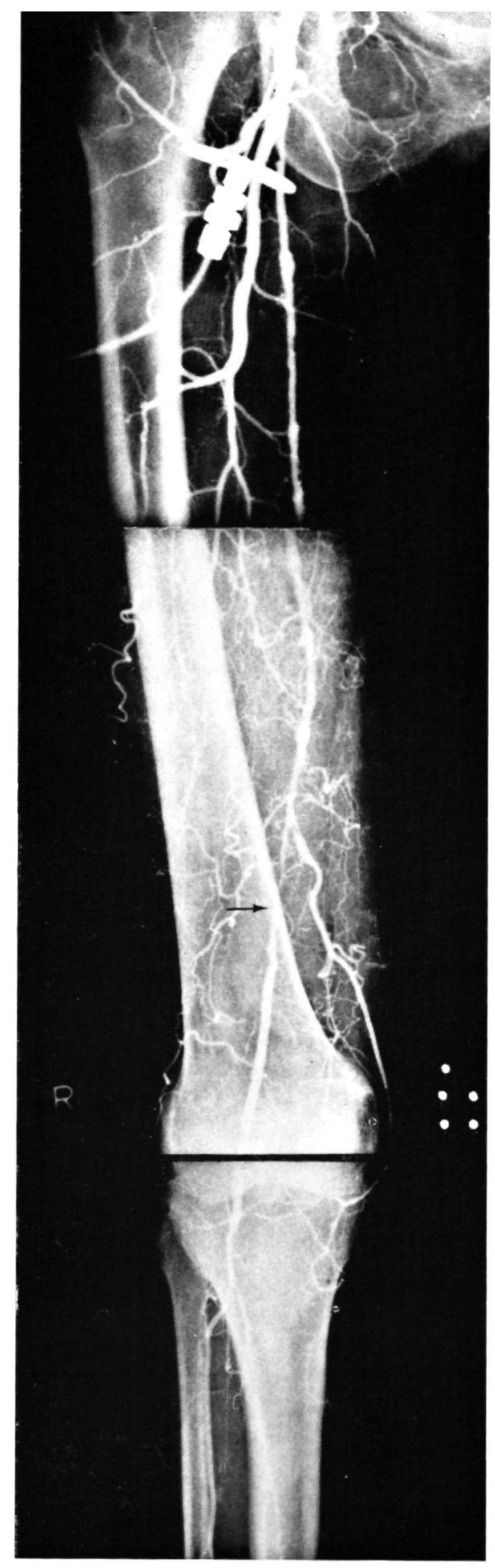


from both legs but the curve obtained from the right leg was higher compared to the left with an improved rising part, indicating an improved perfusion of the right calf compared to the left (Fig. 46b). These findings were reported as compatible with a subnormal but open vein bypass. This was confirmed by a femoral angiogram demonstrating the endarterectomy with a very irregular arterial wall and patent but stenotic proximal anastomosis of the vein bypass graft to the proximal popliteal artery (Fig. 47).

\subsubsection{Case report (B.-L.)}

The rather poor results of surgery in the poor run-off subgroup do not imply that reconstructive surgery is always useless.

This can be demonstrated by the case report of a 60 -year-old woman (B.-L.) whose angiogram showed a total occlusion of the left distal part of the superficial femoral artery and of the proximal part of the popliteal artery with a good collateral circulation as well as an arteriosclerotic tibial artery system with occlusion of the posterior tibial artery. On the right a serious stenosis was present in the popliteal artery (Fig. 48). The tracer study showed a pathologic curve pattern with poor perfusion on the left. On the right a rather high peak activity was seen in spite of stenosis (Fig. 49). A vein bypass was applied to the most distal part of the left popliteal artery which was narrow and demonstrated arteriosclerotic plaques. After surgery the tracer study was repeated, and the curve pattern was slightly improved. On the scintiphotos the bypass was clearly visualized in its distal anastomosis. Utilizing small regions of interest as mentioned above the activity turnover in both pathways could be illustrated diagramatically (Fig. 50). This illustrates that the passage of the bolus through the bypass plays an important role in the perfusion of the calf. However, an important role was still played by the collateral arteries displaying a higher rising part of the curve and a higher rising plateau, probably due to a slow but definite perfusion of the muscle tissues around the collateral vessels.

\subsection{Discussion}

The analysis of the parameters before and after management indicates that the P.I. value is the best parameter for the evaluation of the surgical results in subgroups II, III and IV. Peak activity was restored in 26 of 28 legs in category A of subgroup III and in all 17 legs in category A of subgroup IV. Also an "improvement" was demonstrated in category B of subgroup IV.

In spite of successful surgery there is an indication that the values for category A do not always reach the values obtained in the patent subgroup. The following reasons are offered as an explanation. 


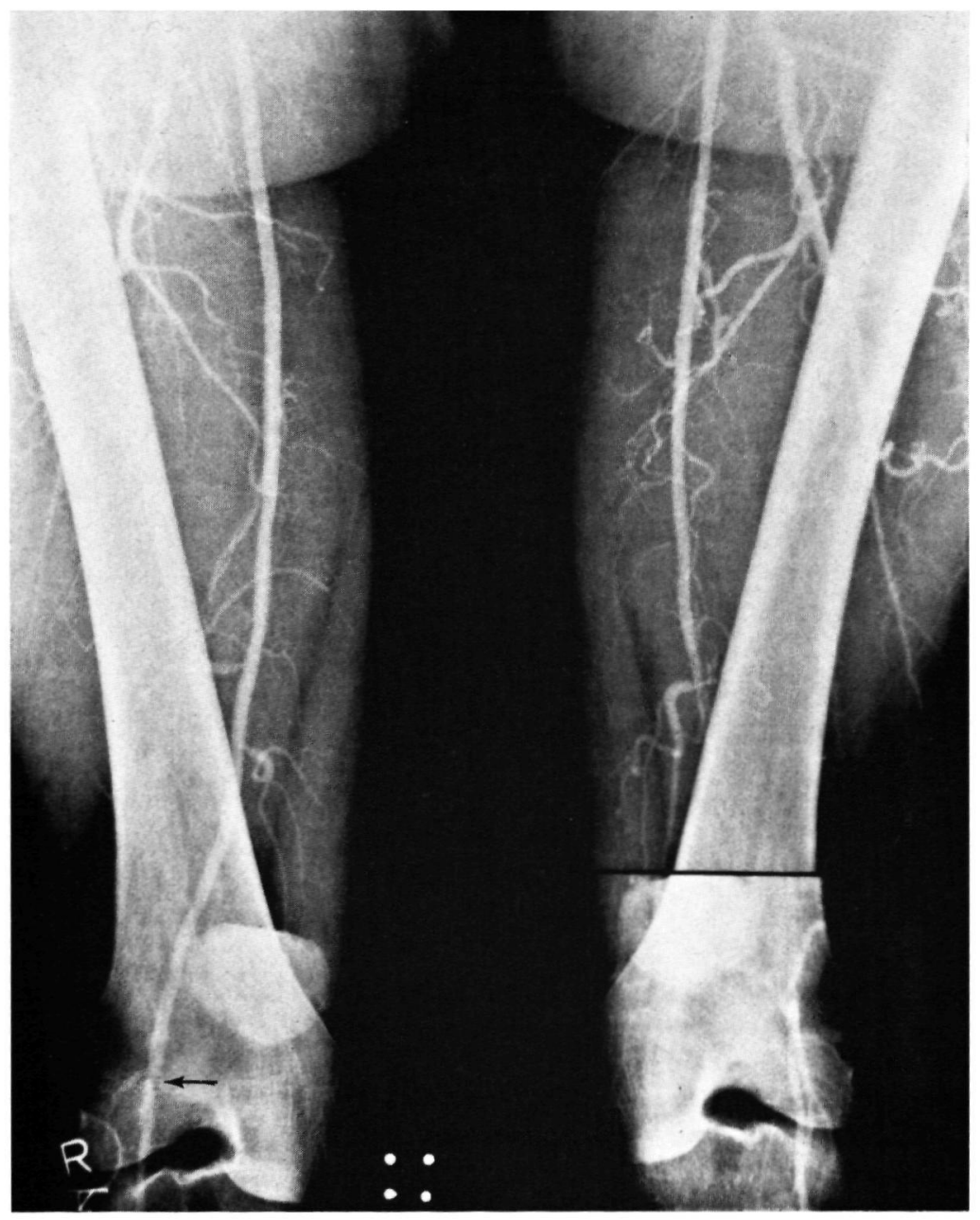

Fig. 48: Arteriogram of patient B.-L. Multiocclusions on the left and stenosis on the right (indicated by arrow).

1. Extensive arteriosclerotic changes in arterial walls persisting after reconstruction of an occluded segment.

2. Relative inefficiency of the hemodynamics of the end-to-side anastomosis. It is suggested that following such an anastomosis a flow pattern is produced which is directed to the opposite wall (Schultz, 1967). The turbulent flow pattern results in dissipation of potential energy in order to maintain random motion of fluid particles. 

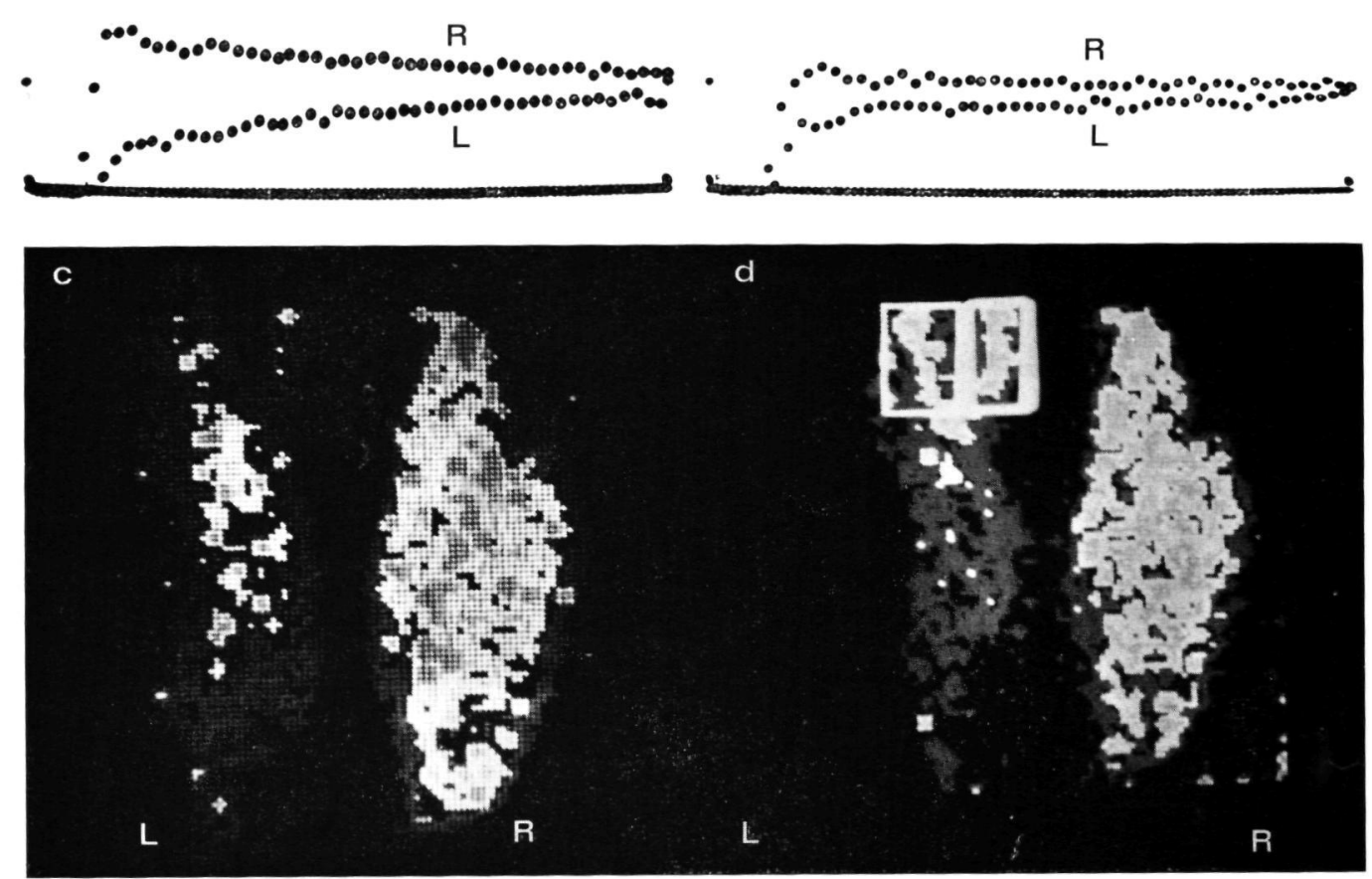

Fig. 49a: Preoperative curve of patient B.-L. Note the severely diminished perfusion pattern. Fig. 49b: Postoperative curve of the same patient. Note minor improvement in the left leg. Fig. 49c: Black-and-white reproduction of color-coded scintiphotos of the postoperative study demonstrating the still diminished perfusion on the left side.

Fig. 49d: Same study, showing 2 areas of interest selected on the bypass region and the collateral circulation.

3. Postoperative changes in reactive hyperemia. Strandness (1966) reported a persistently abnormal exercise response after reconstructive vascular surgery.

4. Possibly inadequate inflation of the pressure cuffs due to painful surgical scars.

5. Differences in other relevant factors (like age) between patent legs and successfully treated legs. 


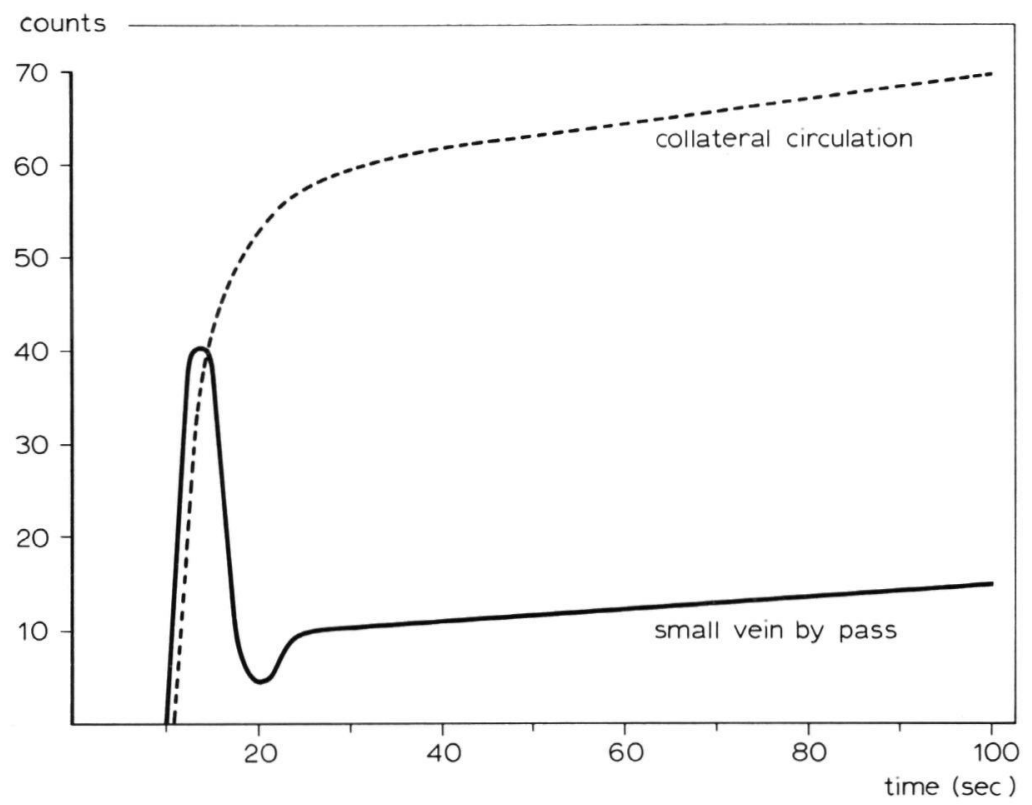

Fig. 50: Graphic representation of the activity-time pattern of the data obtained from the two areas of interest shown in Fig. 49d.

In all patent legs, whether before or after treatment, a characteristic normal activity pattern with a demonstrable peak was preserved, even when the mean P.I. values were low. In category $\mathrm{C}$ of the patent and stenotic subgroups a decreased P.I. value was observed. Several explanations might be considered.

1. A shunting mechanism. In a patient with multisegmental occlusions in one leg and a stenosis in the other it is conceivable that during the peak flow of reactive hyperemia a major part of the blood would be shunted to vasculature with the relatively lower resistance of the better leg. This is a stealing mechanism from the leg with a higher resistance. Shunting mechanism even within the same leg was reported by Strandness et al. (1969), who observed the disappearance of posterior tibial artery pulsations distal to an occlusion during muscular exercise. Although in theory a shunting mechanism is a possible factor, the statistical analysis of the changes in $t_{\max }$ and perfusion index values in 52 untreated patent and stenotic legs as related to the way of treatment of the opposite leg, did not show a systematic relation. This weakens the shunting mechanism as a major explanation. 
2 Naturally progressive course of the disease Progress of arteriosclerotic disease was reported by Boyd (1962) who found the chance of experiencing new occlusions to be $50 \%$ in 5 years On the other hand the amputation rate was only $14 \%$ per year, demonstratıng the relatively benign course of arteriosclerosis obliterans The slow progression of the disease in the patent and stenotic subgroup will in general be clinically silent Strandness et al (1966 b) reported a progression of $52 \%$ during an average of three years in 60 patients In 5 out of 11 patients with serious stenosis they found a complete occlusion of the vessels In our study the time between the pre- and postoperative tracer study is rather short, and we assume that the natural progressive course of the disease, except in a few cases, has only played a minor role in the explanation of the lowered P I values

3 Another probably relatively important contributing factor is the technical variation in the study Shortly after surgery a painful operation scar precludes raising the pressure in the cuffs around the thighs to preoperative values $(200-300 \mathrm{~mm} \mathrm{Hg})$ Due to the lower pressure the ischemic period might have been less complete, resulting in relatively lower postoperative values

4 Physiologic day-to-day varıations Spontaneous day-to-day varıations in normals as well as in patients with occlusive disease were reported by Lindbjerg (1969) utılızıng the local Xenon clearance technıque, by Isacsson (1972) utilızing the venous occlusion plethysmography, as well as by Gundersen (1973) and Nielsen et al (1973), both measuring systolic blood pressures with a mercury strain gauge

In the patients the difference in the plateau level seems to be of less important diagnostic value In theory a lower plateau is thought to be compatible with a reduced vascular volume (see chapter 122 ) MacIntyre et al (1952) as well as Cuypers et al (1962) obtained a lower plateau in cases with serious occlusive disease when utılızing radioiodınated human serum albumın When using a freely diffusıble tracer lıke 99 'Technetıum-pertechnetate, the decreased plateau is suggestive not only of a reduced vascular volume, but also of a reduced muscular volume of the leg, which might correlate with a certain degree of atrophy of the diseased leg In our material nearly all cases with a plateau difference the plateau was equalized, or the difference became insignificant after successful surgery The surgical treatment in subgroup $V$ (poor run-off) was disappointing In this subgroup only a partial reconstruction was possible in most cases The femoro-popliteal grafting procedures highly depend on the vascular status of the arterial tree distal to the occlusion

Many authors have reported high fallure rates in grafts of small size, especially when the graftıng technique is complicated due to an atheromatous core of the 
arterial wall at the anastomosing site. High flow rates are probably important in preventing re-thrombosis in the early postoperative course (Terry, 1972; Little, 1968).

Bliss (1973) measured the blood flow during the surgical procedure utilizing an electromagnetic flowmeter as well as blood pressure measurement. He reported an increased peripheral resistance, due to the occlusion of two or more lower leg arteries and due to arteriosclerotic irregularities in all three tibial arteries without any occlusion, to be an important factor inducing poor surgical results due to early re-thrombosis. Bell (1973), measuring systolic pressure of the leg, reported that patients with multiple occlusions with run-off involment were a critical group. He also doubted whether increasing the inflow would produce any lasting benefit to the distal circulation due to high peripheral resistance. Dedichen (1973) found in $70 \%$ of patients with primary failures, that during surgery significantly lower flow values were obtained in the distal vessels after the reconstruction.

In our material it is not possible to define which part of the poor surgical results is due to the influence of high early failure rate, and which part may be due to a high peripheral resistance.

In this patient group there is no doubt that the development of the collateral circulation is the most important factor in the preservation of the limb.

That individually there is a great variation in the function of this system is obvious from the case report (P.R. 5.14.2.) which demonstrates that the collateral circulation may be so efficient that a (sub)normal perfusion distally from the occlusion can be reached, making the occlusion clinically silent as well as undetectable when utilizing a functional tracer technique. As demonstrated, these occlusions and stenoses are without any consequences, because reconstructive surgery in these cases is unnecessary.

The highest P.I. value from an occluded leg (case report P.R.) was obtained in a patient with a pseudoarthrosis on the opposite side. This leg functioned as a compensation during walking because of the impossibility to burden the pseudoarthrotic leg, resulting in extensive muscular activity. This compensating function for the broken leg may have been a tremendous stimulation for further opening and widening of the collateral channels.

Already Buerger (1924) as well as Allen (1931) thought that passive exercise emptying and distending blood vessels was a stimulus to the transport function of blood vessels. Wisham et al. (1953) observed an increased blood flow only when active excercise was performed. Porjé et al. (1967) reported subjective improvement when utilizing a walking and cycling program in patients with occlusive disease. Significant results were reported by Schoop (1973), Schüssel (1965) and Skinner et al. (1967) who demonstrated an effective improvement of the collateral circulation by using a graded exercise program. A further study of the effects of such a program on the parameters would be useful.

Also it seems interesting to investigate the discriminatory power of the combined parameters to distinguish between certain subgroups. Summarizing, the 
following conclusions from the analysis of the parameters before and after management may be drawn:

1. The P.I. value is again the best parameter for the evaluation of the surgical results.

2. The plateau difference is insignificant as a diagnostic parameter.

3. The lowest rate of success of reconstructive surgery was achieved in subgroup V.

4. The function of the collateral circulation varies individually. 


\section{SUMMARY}

Correction of vascular impairment in limbs is becoming a routine due to improved techniques in vascular surgery. To estimate the degree of impaired perfusion and the extent of the improvement after treatment, a functional test is required. The principal objective of this study was to introduce such a test utilizing a radionuclide tracer technicue and the gamma camera.

Chapter I presents a historical background of various attempts to evaluate peripheral arterial perfusion in the legs, and a review of techniques divided into tracer and non-tracer methods. The most important techniques are critically discussed.

Chapter II explains the technique presented in this thesis, the rational for the choice of a freely diffusible tracer, and the role of reactive hyperemia. The gamma camera system is described as well as the set-up of the data analysis equipments employed. The data processing programs and the presentation of the data are also given. The procedure employed is outlined in details.

Chapter III deals with the subject material studied. A group of normal subjects and a group of patients with claudication are included. An arteriographic classification is described. This classification applied to the patients' legs resulted in their subdivision into five subgroups. The incidence of anatomic localizations in patients is stated, and compared to those given in literature.

Chapter IV presents an analysis of the normal and pathologic curve patterns. Four parameters are selected. The influence of the severity of occlusive arterial disease on the arrival and distribution of the radioactivity in the leg is demonstrated.

The interpretation of the data analysis is presented. The value of activitytime curve parameters and serial scintiphoto patterns in differentiating between aorto-iliac and femoro-popliteal occlusions is described. Pathologic activity distribution in patients with a poor run-off is analyzed. After vascular surgery changes in the curve pattern and the imaging of activity distribution reflected the function of the inserted bypass grafts. Imaging the transport of the tracer in the grafts in some patients is presented. The difference between the function of the collateral circulation and a bypass graft is discussed. Technical artifacts related to the bolus injection technique and reactive hyperemia are also described. 
Chapter $\mathrm{V}$ presents a statistical analysis of the results in the normal subject group as well as in the patients studied. The tracer parameters were evaluated according to side (right versus left), age, and sex. Differences in obtained values between males and females in the normal group are discussed. In the claudicant group the clinical stage was correlated to the angiographic diagnosis. The values of the obtained parameters in the same subject were compared and statistically analyzed resulting in the selection of the perfusion index as the best parameter. The results answer the questions posed in the purpose of this investigation. The test proved to be useful in the differentiation between patients with false claudication complaints due to non-arterial disease, and patients with true claudication. It was also demonstrated that absence of complaints is not always accompanied by a patent vasculature. The overlapping values obtained in subgroups with occlusive arterial disease and poor run-off were discussed. The role of the obtained images for further differentiation is illustrated.

The division of the subgroups into three categories according to the type of treatment is explained. The parameter values were subsequently evaluated before as well as after management. Several explanations were offered for the decreased perfusion index values in the untreated category of the subgroups with patent vasculature or stenosis in only a single vascular segment. Significant improvement was noted in the subgroups even when only a partial reconstruction was possible. The fact that the parameter values obtained in the successfully treated category did not reach the values obtained in the patent subgroup is discussed. No significant changes were observed in the legs with a poor run-off. In this subgroup the effect of the high peripheral resistance due to run-off involvement is stressed. The variations in the function of collateral circulation as well as the role of active muscular exercise is demonstrated. From the results the conclusions are drawn, that the technique presented in this thesis can serve as a useful, non-invasive, screening test prior to arteriography and as a functional assessment of vascular reconstruction. 



\section{REFERENCES}

Abramson, D I (1963) Drugs used in peripheral vascular disease Amer J Cardiol, 12 203

Allen, A W (1931) The general management of circulatory disorders of the extremities New Eng J Med, 204859

Alpert, J S, Garcia del Rıo, H, Lassen, N A (1966) Diagnostic use of radioactive Xenon clearance and a standardized walkıng test in obliterative arterial disesse of the legs Circulation, 34849

Andersen, A M, Ladefoged, J (1967) Paitition coefficient of ${ }^{139}$ Xenon betwecn varıous tissues and blood in vivo Scand J clin Lab Invest, 1972

Ashburn, W L (1971) Videotape applications in cerebral blood flow studies Central nervous system investigation with radionuclides (Gılson, A J, Smoak, W M, eds) Thomas, Springfield, p 279

Attınger, E O, Sugawara, H, Navarro, A, Anné, A (1966) Pulsatıle flow patterns in distensible tubes Circ Res, 18447

Baddely, J P, Boog, J W, Johns, H E, Stacey, A J (1973) Xeroradiography its use in peripheral contrast medium angıography Clın Radiol G B , 2467

Barcroft, H, Brıggs, M, Gimlette, T M D, Nasrallah, A (1967) Validity of the 137Xenon method for determination of muscle blood flow in man as evaluated by simultaneous venous occlusion plethysmography durıng intravenous infusions of adrenaline Cardiovasc Res, 1229

Bell, G, Short, D W (1968) The measurement of blood flow through muscle from the clearance of radioactive Xenon Suig Gyn Obstet, 12761

Bell, G (1973) Systolic pressure measurements in occlusıve vascular disease to assess run-off pre-operatively Scand J clin Lab Invest (suppl 128), 31173

Bıer, A (1898) Die Entstehung der Collateralkreıslaufs Virchows Archiv, 153306

Bırnholz, J C (1973) Alternatives in the diagnosis of abdominal dortıc aneurysm combined use of isotope dortography and ultrasonography Amer J Roentgenol, 118809

Blıss, B P (1973) Pressure, flow and peripheral resistance measurements durıng surgery for femoro-popliteal occlusion (Preliminary observation on 21 limbs) Scand, J clin Lab Invest (suppl 128), 31179

Blumgart, H L, Yens, O C (1927) Studies on velocity of blood flow I The method utılized J Clin Invest, 41

Blumgart, H L, Weiss, S (1927) Studies on the velocity of blood flow II The velocity of blood flow in normal resting individuals, and a critique of the method used $J \mathrm{Clin}^{\prime}$ Invest, 415

Bollınger, A (1969) Durchblutungsmessungen in der klınıschen Angıologie Bern, Huber

Bollınger, A, Mahler, F, Zehender, O (1970) Kombınıerte Druck und Durchflussmessungen in der Beurteilung arteriellen Durchblutungsstorungen Dtsch med Wschr, 95 1039 
Bollınger, A., Schlumph, M., Butti, P., Grüntzig (1973): Measurcment of systolic ankle pressure with Doppler ultrasound at rest and after exercise in patients with leg artery occlusions. Scand. J. clin. Lab. Invest. (suppl. 128), 31: 123.

Bonde Petersen, F., Siggaard-Andersen, J. (1967): Blood flow in skin and muscle, evaluated by simultancous venous occlusion plethysmography and ${ }^{133} \mathrm{Xe}$ clearance. Scand. J. clin. Lab. Invest., 19: 113.

Bossaert, H., Amery, A., Verstracte, M., Stalpaert, G. (1968): The hyperaemia after reconstructive arterial surgery evaluated by ${ }^{13}$ Xenon. Angiologica. 5: 263.

Bouhoutsos, J., Morris, T. (1973): Femoral artery complications after diagnostic procedurcs. Brit. Med. J., 3: 396.

Boyd, A. M. (1962): The natural course of arteriosclerosis of the lower extremities. Ploc. Roy. Soc Med., 55: 591.

Boysen, E., Dahn, I. (1965): Femoral angıography during maximal blood flow. Acta Radiol. (Diagn.), 3. 543.

Bıoy, H. (1971): Querschnittslahmung, eine fatale angiographische Komplikation. Kasuıstik und Uebersicht. Fortschr. Röntgenstr., 114: 353.

Buchwald, W, Habighorst, L. V., Hulsc, R. (1973): Thermographie bei Durchblutungsstórungen der Extremitaten. Radiologe, 13: 229.

Buerger, L. (1924): The circulatory disturbances of the extremities. Philadelphia, Saunders.

Clausen, J. P., Lassen, N. A. (1971): Muscle blood flow during cxercise in normal man studied by the 133-Xenon clearace method. Cardiovase. Res., 5: 245.

Conn, H. L. Jr. (1961): Equilibrium distribution of radioxenon in tissue Xenon-hemoglobin association curve. J. Appl. Physiol., 16: 1065.

Cooper, F. W., Elkin, D. C., Shea, P. C., Dennis, E. W. (1949): The study of periphcral vascular disease with radioisotopes Surg. Gyn. Obstet., 88: 711.

Crawford, E. S., Beall, A. C., Moyer, J. H., De Bakey, M. (1957): Complications of aortography. Surg. Gyn. Obstct., 104: 129.

Cresti, M., Steger, C. (1962): The cortelation between the effects of morphology and function on the collateral circulation in the obliterative arteriopathy of the inferior limbs Angiology, 13: 271.

Cronestrand, R., Juhlin-Dannfeldt, A., Wahren, J. (1973): Simultaneous measurements of external ilace artery and vein blood flow after reconstructive vascular surgery: Evidence of increased collateral circulation during exercise. Scand. J. clin. Lab. Invest. (suppl. 128), 31: 167.

Cuypers, Y., Merchic, G. (1962): Elude de la circulation sanguine périphérique à l'aide

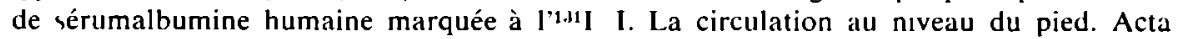
Cardiologica, 17: 117.

Cuypers, Y., Merchie, G. (1962): Etude de la circulation sanguıne pétiphérique à l'aide de

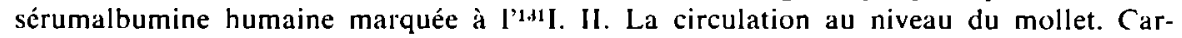
diologica, 41: 166.

Cuypers, Y., Baudinet, V., Baudinet-Robinet, Y, Merchie, G. (1964): Etude de la circulation sanquine périphérıque à l'aide de sérumalbumine humaıne marquée à $\left.\right|^{* 1}$. III Analyse des courbes enrégistrées sur le pied et le mollet. Acta cardiologica, 19: 248.

Dedıchen, H. (1973): Prognostic significance of intra-operative flow and pressure measurements in reconstructive vascular surgery. Scand. J. clin. Lab. Invest. (suppl. 128), 31: 189.

Derrıck, J. R., Logan, W. D., Howard, J. M. (1958): Pitfalls of translumbar aortography and peripheral arteriography. Arch. Surg., 76: 517. 
Dibos, P E, Muhletaler, C A, Natarajan, T K, Wagner, H N Jr (1972) Intıavenous radionuclide arterıography in peripheral occlusive arterial disease Radiology, 102181

Dohn, K, Gravenhorst, J S, Jarløv, N V (1956) Volume recorder usable during functional states Rep Steno Mem Hosp (Kbh), 6141

Dongen van, R J A M (1957) Aortographic study of the collateral circulation in cases of occlusion of the aorta and of the pelvic arteries Arch Chir Neerl, 9203

Ectors, P (1970) Une complicatıon rare de l'aortographie la pancreatıte aıgue Lyon Chır, $66 \quad 417$

Edwards, E A (1959) Postamputatıon radıographic evidence for small drtery obstruction in arterıosclerosıs Ann Surg, 150177

Ekblom, B , Astrand, P-O, Saltın, B, Stenberg, J , Wallstrom, B (1968) Effect of traınıng on circulatory response to exercise J Appl Physiol, 24518

Elkın, D C, Cooper, F W, Rohrer, R H, Miller, W B, Shea, P C, Dennıs, E W (1948) The study of peripheral vascular disedse with radioactive isotope Surg Gyn Obstet, 871

Enjalbert, A, Gideon, A, Mathe, J (1968) A propos de 500 cas d aortographie abdomınale par vole translumbaire Rev Med Toulouse, 4/6 I 497

Fagrell, B (1973) Digital pulse plethysmography and digital blood pressure medsuiement in the evaluation of arterial circulation in the lower limb Scand $J$ clin Lab Invest (suppl 128), 31117

Fish, P J, Kakkar, V V, Corrigan, T, Nicolaides, A N (1972) Arteriogıaphy using ultrasound Lancet 11269

Flores Izquierdo, G, Cuaron, A, Guerrero, M, Cobos, M Trevıno, H Ramırez de Cervantes, M E (1968) Scanning of the peripheral circulation of the limbs J Cardiovasc Surg, 977

Fontaine, R, Dubost, C (1954) Les greffes vasculaıres 56e Congres francais de chıurgıc, p 129, Paris Association francalse de chirurgie

Freeman, L M, Midelzum, R (1968) Diagnosss of aortic aneurysm with radionuclide anglography Amer J Surg, 116433

Friedell, M T, Schaffner, F, Pickett, W J, Hummon, I F (1949) Radioactıve sotopes in study of peripherdl vascular disease Arch Int Med, 83608

Frøysaker, T (1973) Lumbar sympatheclomy in impeding gangrene and foot ulcer Scand J clın Lab Invest (suppl 128), 3171

Gardner, T, Rhodes, B A, Greyson, N D et al (1972) The clinical usefulness of leg scanning in arterial insufficiency using radioactive microspheres Surg Forum, 23247

Gerritsen, H A, Kazem, I, Jong, de J, et al (1971) Dynamıc evaluation of peripheral blood flow before and after vascular surgery with iv $99 \mathrm{mTc}$ Abstracts of papers presented at the 2 nd Congres of the European Associdtion of Rddiology Int Congress Series no 230, Amsterdam, Excerpta Medica, p 166 (abst 415)

Gerritsen, H A, Kazem, I, Hasman, A Kuypers P J (1974) A new approach to the evaluation of peripheral vascular disease using the gamma camera Radiology, $112 \quad 115$

Gerritsen, H A, Kazem, I, Hasman, A Kuypers, P J (1975) Dynamic evaluation of peripheral muscle perfusion following vascular surgery Dynamic studies with radioisotopes in medicine Vienna I A E A, 293

Gerritsen, H A, Kazem, I, Lacquet, L K, Kuypers, P J (1975) Evaluation de l atteinte vasculaire peripherıque avant et apres chirurgie vasculaire, a l'aide d'une camera a scintillations (1975) Angeiologie, 41 
Giargiana, F A Jr, Siegel, M E, Everette, J Jr, Rhodes, B A, Wagner, H N Jr, White, R I Jr (1973) A prelımınary report on complementary roles of arteriography and perfusion scanning in assessment of peripheral vascular disease Radiology, 108619

Grill, C (1933) Plethysmographische Untersuchungen uber das Arm und Beın Volumen wahrend und nach der Arbeit, welche die Zırkulationsverhaltnisse im Gefasssystem beleuchten Skand Arch Physiol, 671

Grımby, G, Haggendal, E, Saltın, B (1967) Local '1'Xenon clearance from the quadrıceps muscle during exercise in man J Appl Physiol, 22305

Gundersen, J (1970) Measurıng digital blood pressure Bıological Engıneerıng Society, 10th Anniversary Conference, Oxford, 1970 Wld Med, 670

Gundersen, J (1973) Standardized multısegmental measurements of blood pressute fot quantitative evaluation of the circulation in lımbs Scand J clın Lab Invest (suppl 128), 31111

Haımovicı, H, Shapıro, J H, Jacobson, H G (1960) Serial femoral arterıography in occlusive disease Amer J Roentgenol, 831042

Haimovicı, H (1967) Patterns of arteriosclerotıc lesıons of the lower extremity Arch Surg, 95918

Hall, K V, Fjeld, N B (1973) Peroperatıve assessment of I un-off by electromagnetıc flowmetry Scand J clın Lab Invest, (suppl 128), $31 \quad 385$

Hallbook, T , Mănsson, B , Nilsen, R (1970) A straın gauge plethysmograph with electrical calıbration Scand J clin Lab Invest, 25413

Hallbook, T, Ling, L (1973) Calf plethysmography by strain gauge technique Effect of vascular surgery Scand J clin Lab Invest, (suppl 128), 3185

Hallbook, T (1973) Strain gauge pulse recordıng in postoperatıve management of vasculdı reconstruction Scand J clin Lab Invest, (suppl 128), 31193

Handling and disposal of radioactive materials in hospitals and medical research establishments (1965), I C R P Publ 5, Oxford, Pergamon

Harper, P V, Andros, G, Lanthrop, K A (1962) Prelımınary obsetvation on the use of sıx hours 99mTc as a tracer in biology and medicıne Semianual report to the Atomic Energy Commission, 1876

Hasman, A, Groothedde, R T (1972) Computer-assisted dynamic and static studies performed with the gamma-camera Proceedings of symposium on medical istotopes scintigraphy Monaco, 1972, I A E A -SM-164/37

Hasman, A, Groothedde, R T (1973) A data-processing system for high resolution gamma-cameras and scanners Proceedings of third symposium on sharing of computer programs and technology in nuclear medicine Miamı, Florida, U S A E C , 209

Hebestreıt, H P, Slıcht, L, Lutgemeıer, J, Grajales, R, Klınke, J D (1972) Ergebnısse der Muskeldurchblutung mittels der Xenon-133-Clearance nach individuell dosserter ischamischer Arbeit bei Gesunden sowie bel Patıenten vor und nach Gefassoperation Fortschr Rontgenstr, 117141

Heidenreich, P, Fischer, M, Kempken, K, Pabst, H W, Scherer, H J (1973) Die intravenose Perfusıonsserienszintıgraphie bei perıpheren arteriellen Gefassverschlussen Fortschr Rontgenstr, 119545

Hess, H (1956) Über die Wırkung vasodılatıerender Massnahmen auf den Bluteınsırom In die untere Extremitat beı obliterierenden Gefasserkrankungen Z Klın Med, 154165

Heuck, F, Muller, R (1973) Zur Kenntnıs der aneurysmatıschen Form der Arterıosklerose der untere Extremitat Fortschr Rontgensir, (suppl 1973), Rontgenkongress, Wien, p 246 
Hewlett, A W, Zwaluwenburg, J G van (1909) Method for estımating the blood flow In the arm Prelımınary report Arch Int Med, 3254

Hewlett, A W, Zwaluwenburg, J G van (1909-10) The rate of blood flow in the arm Heart, 187

Hılton, S M (1962) Local mechanısms regulatıng perıpheral blood flow Physıol Rev, (suppl 5), 42265

Hilton, S M (1963) Discussion of evidence of kınıns as agents of vasodilatator ieaclions Am New York Acad Sc 104275

Hıshıda, Y (1963) Perıpheral arteriography usıng reactıve hyperemıa Jap Clın J 27349

Hoffmann, D C (1968) An assessment of the Xenon-133 method of measurıng muscle blood flow Austr N Z J Surg $38 \quad 66$

Hokanson, D E, Mozersky, D J, Sumner, D S, McLeod, F D Jr, Strandness, D E Jr (1972) Ultrasonic arteriography, a noninvasive method of arterial visualization Work in progress Radıology, 102435

Holman, B L, Hıll, R, Davıs, D O, Potchen, E J (1972) Regıonal cerebral blood flow with the anger camera $J$ Nucl Med, 13916

Holman, B L, McNeıl, B J, Adelstein S J (1974) Regional blood flow studies with radiossotopes Proceedings of symposium on dynamic studies with radioısotopes in clınical medicıne and research Knoxville, Tennessee, July 15-19, I A E A -SM-185/102

Holsteın, P, Lassen, N A (1973) Radiolsotope clearance technique for mcasurement of dıstal blood pressure in skın and muscles Scand J clın Lab Invest, (suppl 128), 31143

Hubbard, J P, Preston, W N, Ross, R A (1942) The velocity of blood flow in infants and young chıldren, determıned by radıoactıve sodium J Clın Invest, 21613

Husnı, E A (1967) The edema of arterial reconstruction Circulation, (suppl 1), 35-36 169

Isacsson, S-O (1972) Venous occlusion plethysmography in 55-yeat-old men Acta Med Scand, (suppl 537), p 19

Ishu, Y, Maclntyre W J (1971) Measurement of heart chamber volumes by analysis of dilution curves simultaneously recorded by scintillation camera Circulation, 4437

Jones, E L, Wagner, H N Jr, Zuidema, C D (1965) New method for studyıng peripheral circulation in man Arch Surg 91725

Kahn, P C, Callow, A D (1965) Selective vasodılatation as ald to angıography Amer J Roentgenol, 94213

Kahn, P C, Boyer, O N, Moran, J M (1968) Reactıve hyperemia in lower extremity arterıography evaluation Radiology, 90975

Kappert, A, Rosler, H (1972) Eıne neue Methode zur nuclearmedizınıschen dynamıschen Analyse der peripheren Strohmbahn VASA, 1285

Kety, S S (1949) Measurement of regional circulation by the local clearance of radioactıve sodium Amer Heart J, 38321

Kety, S S (1951) The theory and applications of the exchange of inert gas at the lungs and tissues Farmacol Rev, 11

Khobreh, M T, Roy, P (1966) Muscular angıographic patterns in lower extremıtıcs before and after exercise Ann Surg, 164883

Killen, D A, Foster, J H (1966) Spınal cord injury as a complication of contrast angıography Surgery, 59969

Krieger, H, Storaaslı, J P, MacIntyre, W J, Hodden, W D, Friedell, H L (1952) The use of radioactive iodinated human serum albumin in evaluatıng the peripheral circulation Ann Surg, 136357 
Kriss, J. P., Enright, L. P., Hayden, W. H., Wexler, L., Shumway, N. E. (1971): Radioisotopic angiocardiography. Wide scope of applicability in diagnosis and evaluation of therapy in diseases of the heart and great vessels. Circulation, 43: 792

Lambert, J., Neven, C. (1950): Réponses vasculaires locale à l'ischémie momentanée d'un membre chez l'homme. Arch. Int. Physiol., 58: 287.

Lambert, J., Neven, C, Stevens, A. (1951): Réactions vasculaires différentes dans la peau et le muscle chez le chien après interruptions momentanées de la circulation artérielle. Arch. Int. Physiol. 59: 451.

Lambert, J., Bruwier, H., Dantinne, R., Otto, M., Vandeghem, P., Lancker M. A. van (1956): Réactions vasculaires provoquées dans le muscle strié au repos chez le chien par l'ischémie temporaine expérimentale. I. Investigation par des méthodes multıples en circulation normales et en circulation collatérale. Arch. Int. Physiol., 64: 623.

Lane, S. D., Patton, D. D., Staab, E. V., Baglan, R. J. (1972): Simple technique for rapid bolus injection. J. Nucl. Med., 13: 118.

Larsen, O. A. (1972): Xenon-133 methods for determining peripheral blood flow and blood pressure in patients with occlusive arterial disease. Angiology, 23: 153.

Larsen, O. A. (1973): Xenon-133 clearance studies during walking. Effect on muscle and skin blood flow. Routine application with comment on branch thrombosis below the knee Scand. J. clin. Lab. Invest., (suppl. 128), 31: 89.

Larsen, O. A., Lassen, N. A. (1973): Treatment of chronic gangrenous skin lesions with measures increasing distal blood pressure with special regard to induced moderate hypertension. Scand. J. clin Lab. Invest., (suppl. 128), 31: 213.

Lassen, N. A., Lindbjerg, I. F., Munck, O. (1964): Measurement of blood flow through skeletal muscle by intramuscular injection of Xenon-133. Lancet, I: 686.

Lassen, N. A., Kampp, M. (1965): Calf muscle blood flow during walking studied by the Xe-133 method in normals and in patients with intermittent claudication. Scand. $J$ clin Lab Invest., 17: 447.

Lassen, N. A, Lindbjerg, I. F., Dahn, I. (1965): Validity of the Xenon-133 method for measurement of muscle blood flow evaluated by simultaneous venous occlusion plethysmography. Observations in the calf of normal man and in patients with occlusive vascular disease. Circ. Res., 16: 287.

Lassen, N. A., Larsen, O. A., Sørensen, A. W. S., Hallbook, T, Dahn, I., Nilsén, R., Westling, H. (1968): Conservative treatment of gangrene durıng mineralocorticord induced moderate hypertension. Lancet, I: 606.

Lériche, R., Bertrand, I. (1946): Thromboses artérielles. Mason, Paris, p. 350

Lewis, T., Grant, R. (1925): Observations upon reactive hyperaemia in man. Heart, 12: 73

Lindbjerg, I F (1965 a): Measurement of muscle blood flow with Xe-133 after histamine injection as a diagnostıc method in perıpheral arterial disease. Scand. J. clin. Lab Invest., 17: 371 .

Lindbjerg, I. F. (1965 b): Diagnostic application of the Xenon-133 method in peripheral arterial disease. Scand. J. clin. Lab. Invest., 17. 589.

Lindbjerg, I F. (1966 a): Leg muscle blood flow measured with Xenon-133 after ischaemia periods and after muscular exercise performed during ischaemia. Clin. Sci, 30 - 399.

Lindbjerg, I. F., Andersen, A. M., Munck, O., Jorgensen, M. (1966 b): The fat content of leg muscles and its influence on the ${ }^{133}$ Xenon clearance method of blood flow measurement Scand. J. clin. Lab Invest, 18: 525. 
Lindbjerg, I F (1967) Routıne use of the Xenon-133 clearance method in peripheral circulation studies with special regard to its correlation to angiography Scand J clin Lab Invest, (suppl 93) 123

Lindbom, A (1950) Arteriosclerosis and arterial thrombosis in lower limb Acta Radıol (Diagn), suppl 80

Little, J M, Sheıl, A G R, Loewenthal, J, Goodman, A H (1968) Prognostic value of intraoperatıve blood flow medsurements in femoropopliteal bypass veın-grafts Lancet, II 648

Loken, M K, Ponto, R, Bache, R, Burchell, H (1971) Intravenous radiossotope angıo graphy with computer processing of datd Amer J Roentgenol, 112682

Longland, C J (1953) The collateral circulation of the lımb Ann Roy Coll Surg Eng 13161

Lorentsen, E (1973) The plantar ischemia test (Contributıon to the discussion about local blood pressure measurements in patients with peripheral arterid insufficiency) Scand J clın Lab Invest (suppl 128), 31149

Lorenz, W J Adam, W E (1967) Digitale und analoge Auswertung von Aufnahmen mit der Scıntillationskamerd J Nucl Med, 64367

Ludbrook, J (1966) Collateral artery resistance in the human lower limb J Suig Res 6423

MacAfec, J (1957) A survey of complications of abdominal aortography Radiology 68825

MacIntyre, W J, Pritchard, H W, Ecksteın, R W, Friedell, H L (1951) The determination of cardiac output by a contınuous recording system utılızıng lodinated (13i) human serum albumın I Anımal studies Circulation, 4552

MacIntyre, W J, Storaaslı, P J, Krieger, J, Pritchard, W, Friedell, H L (1952) 111 Jlabeled serum albumın its use in the study of cardiac output and peripheral vascular flow Radıology, 59849

Mannick, J A, Hume, D M (1964) Salvage of extremitıes by veln grafis in fal-advanced perıpheral vascular disease Surgery 55154

Margulıs, A R, Nıce, C M Jr, Murphy, T O (1957) Arteriographic manifestations of peripheral occlusive vascular disease Amer J Roentgenol, 8273

Mavor, G F (1956) Pattern of occlusion in atheroma of lower limb arteries Brit J Surg, 43352

May, A G, Berg, L van de, Weese, J A de, Rob, C G (1963) Critıcal arterial stenosıs Surgery, 54250

Mazoyer, J F, Deruty, R, Michel, D, Goutelle, A, Chacornac, R, Barbeau, P J, Bochu, M (1973) Une complication rare de l'arteriographie humerale la paraplegie d propos de 3 observations Lyon Medical, 230435

McEwan, A C (1969) Radiation doses in the handlıng of short living radionuclides Brit J Rad, 42396

Myhre, H O (1973) Ankle systolic blood pressure in lower limb arteriosclerosis measured by ultrasound flow detector Scand J clin Lab Invest (suppl 128), 31129

Neıl, C M (1969) The question of radiation exposure to the hand from handlıng 99mTc J Nucl Med, 10423

Nıelsen, P E, Bell, G, Augustenborg, G, Lassen, N A (1973) Reduction in distal blood pressure by sympathetic nerve block in patıents with occlusive arterial disease Scand J clın Lab Invest, (suppl 128), 3159 
Nielsen, P E, Bell, G, Lassen, N A (1973 a) Strain gauge studies of distal blood pressure in normal subjects and in patients with peripheral arterial disease Analysis of normal variation and reproducibility, and comparison to intraarterial measurements Scand J clın Lab Invest, (suppl 128), 31103

Nıelsen, P E, Lønsmann Poulsen, H, Gyntelberg, F (1973 b) Skın blood pressure measured by a photoelectric probe and external counterpressure Scand, J clın Lab Invest, (suppl 128), 31137

Nılsen, R, Dahn, I, Lassen, N A, Westlıng, H (1967) On the estımatıon of local effectıve perfusion pressure in patients with obliterative arterial disease by means of external compression over a Xenon-133 depot Scand J clin Lab Invest, (suppl 99), 1929

Oldendorff, W H, Kıtano, M, Shımızu, S (1965) Evaluatıon of a sımple technıque for abrupt intravenous injection of radioisotope J Nucl Med, 6205

Pabst, H W, Walchner, W (1952) Kreıslauftest mit radıoactıven Jod Klın Wschr, 30 1011

Patel, D J, Greenfield, J C Jr, Fry, D L (1964) In vivo pressure-lenght-radius relatıonship of certain blood vessels in man and dog Attınger, E $O$ (ed) Pulsatıle Blood Flow New York Mc Graw-Hıll, p 293

Pendergrass, H P, Hildreth, E H, Tondreau, R I , Ritchie, D J (1960) Reactions associated with intravenous urography discussion of mechanisms and therapy Radiology, 74246

Pernow, B, Salın, B, Wahren, J, Cronestrand, R (1973) Muscle metabolısm durıng exercise in patients with occlusive arterial disease Effect of reconstructive surgery Scand J clın Lab Invest, (suppl 128), 3121

Peterson, L H (1964) Vessel wall stress-relationship Attınger EO (ed) Pulsatile blood flow New York, Mc Graw-Hıll, p 263

Petren, T, Sjostrand, T, Sylven, B (1937) Der Eınfluss des Traınungs auf die Haufıgkeıt der Kapillaren in Herz und Skeletmuskulatur Arbeitsphysiol, 9376

Protection of the patıent in radionuclide investigations (1971) ICR P Publ 17, Oxford, Pergamon, p 79

Puel, P, Enjalbert, A, Gedeon, A (1968) L'exploratıon fonctionelle des arteriopathies des membres inferieurs par le Xenon radio-actıf Acta Chır Belgica, 5407

Reynolds, $O$ (1883) An experimental investigation of the circumstances which determıne whether the motion of water shall be direct or sinuous and the law of resistance in parallel channels Phılos Trans, 174935

Robıns, B , Bernstein, A (1970) Comparative studies of digital plethysmography and infrared thermography in perıpheral vascular disease Angıology, 21349

Robınson, A S (1956) Acute pancreatıtıs following translumbar dortography Arch Surg, 72290

Roos, A (1962) Poisseuille s law and its limitations in vascular systems Med Thorac, 19 224

Rosenberg, N, Gaughran, E R L, Henderson, J, Lord, G H, Douglas, J F (1956) The use of segmental arterial implants prepared by enzymatıc modification of heterologous blood vessels Surg Forum, p 242

Rosenthall, L (1966) Applications of the gamma-ray scintillation camera to dynamıc studies in man Radiology, 86634

Rosenthall, L, Lefcoc, M (1969) Intravenous radionuclıde angıography J Canad Ass Radıol, 20114 
Roy, A J, Lambert, P B, Frank, H A (1964) Immediate responses of collateral vessels to abrupt arterial occlusion Amer J Physiol, 2061299

Rushmer, R F, Baker, D W, Stegall, H F (1966) Transcutaneous Doppleı flow detection as a nondestructive technique J Appl Physiol, 21554

Saunders, R L, de C H, Lawrence, J, Maciver, D A, Nemethy, N (1957) Pait V The anatomic basis of peripheral circulation in man Redisch, W, Tangco, F F, Saunders, R L de Ch Peripheral circulation in health and disease Grune and Stratton. New York

Sawyer, P N, Kaplitt, M J, Sobel, S, Goldıng, M R, Dennıs, C (1968) Analysıs of perıpheral gas endarterectomy in 127 patıents Arch Surg, 97859

Schaffner, F, Friedell, M T, Pickett, W J, Hummon, I F (1949) Radioactive ssotopes in the study of peripheral vascular disease Arch Int Med, 83620

Scherer, H J, Maurer, P, Bauer, S (1972) Frequence et trattement des oblitcrations alterielles apres Seldınger Lyon Chir, 68449

Schoop, W (1964) Bewegungstherapie bei perıpheren Durchblutungsstorungen Mcd Wclt 1502

Schoop, W (1973) Mechanısm of beneficial action of daly walkıng trainıng of patıents with intermittent claudication Scan J clın Lab Invest, (suppl 128), 31197

Schultz, R D, Hokanson, D E, Strandness, D E Jr (1967) Pressure-flow relatıons of the end-side andstomosis Surgery, 62319

Schussel, H (1965) Das Gehtrainıng beı alteren Patıenten mit chronıschem Beinarterienverschluss Med Welt, 3145

Shepherd, J T (1950) The blood flow through the calf after exercise in subjects with arteriosclerosis and claudication $\mathrm{Cl}_{1} \mathrm{Sc}_{1}, 949$

Siegel, M E, Giargiana, F A Jr, Rhodes, B A, White, R I Jr, Wagner, H N Jr (1973) Effect of reactive hyperemia on the distribution of radioactive microspheres in patients with peripheral vascular disease Amer J Roentgenol, 94213

Siggadrd-Andersen, J , Bonde Petersen, F (1967) Venous occlusion plethysmography and ${ }^{13} \mathrm{Xe}$ muscle clearance measured simultaneously on the calf in normal subjects Scand J clin Lab Invest, 19106

Skınner, J S, Strandness, D E Jr (1967) Exercise and intermittent claudication Circulation, 3623

Smith, B C, Quimby, E H (1945) The use of radioactive sodium in studies of circulation in patients with peripheral vascular disease Surg Gynec Obstet, 45335

Strandness, D E Jr, Radke, H M, Bell, I W (1961) Use of a new simplified plethysmograph in the clinical evaluation of patients with arteriosclerosis obliterans Surg Gynec Obstet, 112751

Strandness, D E Jr, Bell, J W (1965) Peripheral vascular disease Diagnosıs and objective evaluation using a mercury strain gauge Ann Surg (suppl 161), 335

Strandness, D E Jr (1966) Abnormal exercise responses after successful reconstructive arterial surgery Surgery, 59325

Strandness, D E Jr, Stahler, C (1966) Arterıosclerosıs obliterans manner and rate of progression J A M A, 196121

Strandness, D E, Jr, Schultz, R D, Sumner, D S, Rushmer, R F (1967) Ultrasonic flow detection $A$ useful technique in the evaluation of peripheral vascular disease Amer J Surg, 113311

Strandness, D E J $\mathbf{J}_{\mathbf{r}}$ (1969) The selection of patıents for direct arterial surgery Peripheral arterial disease A physıologic approach, Little Brown, Boston 129 
Strandnesı, D E Jr (1969) Collateral cırculatıon in clınıcal surgery Saunders, Phıladelphia

Suy, R, Stalpaert, G, Verstraete, M, Baert, A (1973) Les complications de 1 angeıographıe abdominale Angeiologie, 25, no spec Decembre 317

Terry, H J, Allan, J S, Taylor, G W (1972) The reldtionship between blood flow and fallure of femoropopliteal reconstructive arterial surgery Brit J Surg, 59549

Wagner, H N Jr, Jones, E, Tow, D E, Langan, K (1965) A method for the study of the peripheral circulation in man $\mathrm{J}$ Nucl Med, 150154

Walder, D N (1955) The relatıonship between blood flow, capıllary surface area and sodium clearance in muscle Clın Sci, 14303

Walder, D N (1958) A technique for investıgatıng the blood supply of muscle during exercise Brit Med J, 1255

Watson, D D, Nelson, J P, Gottlieb (1973) Rapid bolus injection of radioisotopes Radiology, 106347

Watt J K (1966) Arterial occlusion in the lower leg Brit Med J, I 18

Westerman, B R, Shorma, R, Fowler, F (1968) Relatıve importance of resolutıon and sensitivity in tumor detection $J$ Nucl Med, 9638

Westling, H (1973) Effect of vasodılator drugs in occlusive vascular disease Scand I clin Lab Invest (suppl 128), 31207

Whitney, R J (1949) The measurement of changes in human limb volume by means of a mercury-in-rubber strain gauge J Physiol, 1095

Wilder, R J, Steıcken, F M (1960) Necrosıs of the entıre gastrointestinal tract following translumbar dortography Arch Surg, 80198

Wisham, I, Abramson, A, Ebel, A (1953) Value of exercise in peripheral drterial disease J A M A, 15310

Witten, D M, Hirsch, F D, Hartman, G W (1973) Acute reactions to urographic contrast medium Amer J Roentgenol, 119832

Zelıs, R, Mason, D (1969) Mechanısms of systemıc hemodynamı response during lımb reactive hyperemı Amer J Physiol, 2171742

Zıerler, K L (1965) Equations for measurıng blood flow by exteınal monitorıng of radioisotope Circ Res, 16309

Zimmerman, R E, Holman, B L (1972) Modulation transfer for the PHO/Gamma III and PHO/Gamma H P scintillation camera using ${ }^{00_{m} \mathrm{Tc}}$ and ${ }^{11} \mathrm{Xe} \mathrm{J}$ Nucl Med, 13481

Zolle, I, Rhodes, B A, Buchanan, J W (1968) Properties and uses of radioactive albumın microspheres J Nucl Med, 9363 
Date of birth

Premedical education

Medical education

Residencies and postgradual training:

Radiology Board Certification

Present position
August 12, 1942 - Goes .

College of St. Willibrord Goes, (H.B.S. B), 1960.

University of Nijmegen, M.D. 1969.

St. Radboud University Hospital Nijmegen, 1969 to 1975.

Resident radiotherapy and nuclear medicine,

(Chairman Prof. Dr. I. Kazem) 1969 to 1971.

Resident roentgendiagnosis, (Chairman Prof. Dr. Wm. Penn) 1971 to 1974.

November 1974.

Staff radiologist, Hospital Foundation Venlo - Tegelen. 


\section{STELLINGEN}

\section{I}

Omdat de klinische diagnose van de arterieële insufficientie vaak onzeker is, verdient het aanbeveling deze te ondersteunen met een eenvoudige funktie-test.

\section{II}

Onderzoek naar de aanwezigheid van perifeer vaatlijden, waarbij tevens inzicht kan worden verkregen in de mate en de localisatie van de afwijkingen, is goed mogelijk met het gamma camera systeem.

\section{III}

$\mathrm{Na}$ eventuele operatieve behandeling geven de verkregen veranderingen van activiteitsverdeling en curvepatroon een indruk van het bereikte operatie resultaat.

\section{IV}

In tegenstelling tot in een hooggespecialiseerde universiteitskliniek, valt het in een perifere kliniek niet te verwachten, dat door invoering van "computerized axial tomography" een daling zal optreden in het aantal onderzoeken met andere technieken (w.o. angiografie, pneumoencephalografie en scintigrafie).

V

Middels een zorgvuldig begeleid "trimschema" kan door spieroefening de arterieële circulatie zowel subjectief als objectief zodanig verbeteren, dat in veel gevallen de claudicatie patient een operatieve ingreep kan worden bespaard.

\section{VI}

Bij skeletscintigrafie met ${ }^{99}$ "1 $\mathrm{Tc}$-fosfaat verbindingen kan uit de afbeelding van de nieren waardevolle klinische informatie worden verkregen.

Vieras F., Boyd Ch. M. (1975) J. Nucl. Med. 16: 1109. 
Indien bij vaatlijders met chronische ulcera chirurgisch ingrijpen niet meer mogelijk is, kan de behandeling ervan toch succesvol zijn door het verhogen van de perfusiedruk, dankzij de introductie van een langdurige matige hypertensie met mineralocorticoïden.

Larsen O. A., Lassen N. A. (1973) Scand J. clin lab. Invest. (suppl. 128), 31: 213.

\section{VIII}

De uiterste remedie tegen stroperij is afschaffing van de jacht.

IX

Met betrekking tot het zuurstoftransport in spierweefsel is het myoglobine te beschouwen als zwaar vrachtverkeer.

De Koning J., van Haren R., Hoofd L. J. C., Kreuzer F. (1976) Fed. Proc. 35: 831, no. 3453.

$$
\mathrm{X}
$$

$\mathrm{Na}$ de definitieve afsluiting van de Oosterschelde met een ondoorlaatbare dam wordt het voor de provincie Zeeland de hoogste tijd haar naam te veranderen in "Rioolwaterland".

\section{XI}

$\mathrm{Na}$ iedere operatieve ingreep in het arterieële vaatsysteem is een controle angiografie noodzakelijk.

\section{XII}

Bij patienten op jonge en middelbare leeftijd, die ooit behandeld zijn geweest wegens een acute arterieële afsluiting, dient te worden gezocht naar een mogelijke plaats van de thrombose haard door middel van angiocardiografie en arteriografie.

Goerttler U., Spillner G., Schlosser V. (1973) Fortschr. Röntgenstr. 3: 311.

\section{XIII}

Zelfs in het oog van een radioloog schuilt een blinde vlek. 
